\title{
The Potential of Industrial Symbiosis: Case Analysis and Main Drivers and Barriers to Its Implementation
}

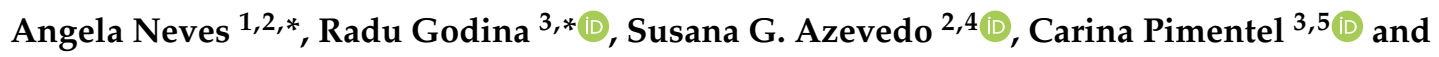 \\ João C.O. Matias 5 (D) \\ 1 Department of Mechanical Engineering, Polytechnic Institute of Viseu, 3504-510 Viseu, Portugal \\ 2 University of Beira Interior, 6201-001 Covilhã, Portugal; sazevedo@ubi.pt \\ 3 UNIDEMI, Department of Mechanical and Industrial Engineering, Faculty of Science and Technology (FCT), \\ Universidade NOVA de Lisboa, 2829-516 Caparica, Portugal; carina.pimentel@ua.pt \\ 4 CEFAGE-Department of Business and Economics, University of Beira Interior, 6201-001 Covilhã, Portugal \\ 5 GOVCOPP and DEGEIT, University of Aveiro, 3810-193 Aveiro, Portugal; jmatias@ua.pt \\ * Correspondence: aneves@ipv.pt (A.N.); r.godina@fct.unl.pt (R.G.)
}

Received: 8 October 2019; Accepted: 9 December 2019; Published: 11 December 2019

check for updates

\begin{abstract}
Industrial symbiosis, which is characterised mainly by the reuse of waste from one company as raw material by another, has been applied worldwide with recognised environmental, economic, and social benefits. However, the potential for industrial symbiosis is not exhausted in existing cases, and there is still a wide range of opportunities for its application. Through a comprehensive literature review, this article aims to compile and analyse studies that focus on potential industrial symbiosis in real contexts, to highlight the margin of optimisation that is not being used. The cases reported in the publications identified here were characterised and analysed according to geographic location, type of economic activity, waste/by-products, main benefits, and the methods employed in the studies. From this analysis, we conclude that there is great potential for applications involving industrial symbiosis throughout the world, and especially in Europe, corresponding to $53 \%$ of the total cases analysed. Manufacturing stood out as the sector with the highest potential for establishing symbiosis relationships, and the most common types of waste streams in potential networks were organic, plastic and rubber, wood, and metallic materials. This article also discusses the main drivers and barriers to realising the potential of industrial symbiosis. The diversity of industries, geographical proximity, facilitating entities and legislation, plans, and policies are shown to be the main drivers.
\end{abstract}

Keywords: industrial symbiosis; potential industrial symbiosis; sustainability; eco-industrial parks; circular economy

\section{Introduction}

In recent years, resource-intensive use, rising industrialisation and urbanisation, modern lifestyles, energy-intensive use, and land use patterns have led to increased greenhouse gas emissions, with negative consequences for the environment and the population [1-3]. It is therefore urgent to find solutions that do not hinder economic development but can provide ways to reduce carbon dioxide emissions, which are largely responsible for greenhouse gases, and to use resources more efficiently. As a subfield of industrial ecology, industrial symbiosis, which is often defined as a collective approach in which one company's waste is used as raw material by another company [4], can help to address these problems without compromising economic development. This practice is similar to biological processes, in which different organisms associate in a "mutually beneficial relationship" [5], as it allows entities and companies that operate separately to come together in the physical exchange of materials, by-products, energy, and water, with competitive advantages for all participants [6]. In addition to 
waste/by-product exchanges, this sharing of resources also encompasses infrastructure sharing and the joint provision of services $[7,8]$.

Some of the problems faced by industries, such as increases in waste, waste treatment costs and high resource consumption, are common in urban areas [9-11]. Thus, if cooperation between companies is extended to urban regions, there is potential for both parties to achieve environmental and economic benefits and to mitigate certain common problems. This cooperation has been referred to in several publications as Industrial and Urban Symbiosis (also called Urban and Industrial Symbiosis) and takes place when waste generated in an urban area is used as a raw material or energy source in industry or when industries provide urban areas with waste heat resulting from their operation [12,13]. However, some authors have also used the term Urban Symbiosis to refer to the use of waste from urban areas as a raw material or source of energy [14-16].

The most well-known case of industrial symbiosis, and the one most often cited in the literature, is in Kalundborg, Denmark. This network arose spontaneously from a self-organising initiative between companies to address water scarcity $[4,5,17]$ and over the years has increased not only in terms of the number of symbioses but also the number of participants and remains a successful case to this day.

However, industrial symbiosis is not confined to the Kalundborg case, and numerous examples of synergistic networks around the world have been reported in the literature, with a wide variety in terms of the numbers of participants, types of economic activities, and how they are organised. In Europe, numerous foci of industrial symbiosis [18] are spread across different countries, and most of the cases reported in the literature are in northern and north-western Europe, with the United Kingdom reporting the highest number of cases [19]. This is due to the voluntary programme that the government has launched to help companies find partners to use their waste as raw material, called the National Industrial Symbiosis Programme [20]. Finland also has several cases of industrial symbiosis, largely arising from the strong presence of the pulp and paper industry, which has driven the creation of synergy relations [21,22]. In Asia, a number of industrial symbiosis initiatives have also been reported, with the highest number of cases in China, largely due to constraints on carbon dioxide emissions and the numerous plans and policies that have been implemented to foster circular economy practices [23-25]. In Japan, there have been cases of industrial symbiosis and industrial and urban symbiosis across several cities, driven by the Japanese Eco-Town Programme that encourages the use of industrial, municipal, and commercial waste in industrial applications, with the aim of boosting the economy and reducing waste disposal $[14,15]$. In North America, and particularly in the US, there have been cases of industrial symbiosis that date back to the late 1970s. The case most frequently mentioned in publications is located in Barceloneta, Puerto Rico, where the strong presence of pharmaceutical companies has spurred the creation and development of industrial symbiosis between various companies [26,27]. Several cases of industrial symbiosis have also been reported in Australia [28,29], Brazil [30], Morocco [31], and Algeria [31].

Despite the recognised benefits that these synergy cases have provided to the environment, the companies involved and the local population, the potential for industrial symbiosis is not exhausted in these existing cases, and there is still great potential for application not only in developed countries but also in countries with developing economies. Of the various articles published on industrial symbiosis, a significant proportion have focused on the best ways to foster industrial symbiosis and the most effective ways of overcoming the various obstacles, including economic, technological, legal, and social obstacles, that are faced in the creation and development of industrial symbiosis. Although some of these publications have a predominantly theoretical content e.g., [23,32,33], most present in-depth studies conducted in real contexts, that is, in a given region, with a holistic analysis of those industries, wastes and products with potential for developing industrial symbiosis e.g., [34-37]. In some of these studies, the implications of these new synergies for the environment, the economic development of companies, and the surrounding population have also been studied e.g., [36,38,39]. This article focuses on the latter type of publication, and identifies these as cases of potential industrial symbiosis. All articles that study the possibility of implementing new industrial symbiosis relationships in a given 
location and that indicate the types of economic activities and industrial symbiosis are included in this designation.

The various studies that have been carried out on potential cases of industrial symbiosis have a wide scope, not only in terms of the characteristics of the synergy network but also in terms of the existence or otherwise of industrial symbioses in the location under study. In places where symbiosis networks already exist, relationships of trust are already established, and there is a knowledge of the benefits of this practice that can help to facilitate the process of mobilising other companies. Studies carried out of the industrial symbiosis networks in Weifang Binhai Economic-Technological Development Area, China [40], in the Västra Götaland region of Sweden [41], and in the Taranto provincial industrial district in Italy [42] represent some of these examples. In these cases, proposals have been put forward to extend the industrial symbiosis network to other companies, with the aim of repurposing some of the waste that was not yet being shared. However, several studies have been published that have proposed the creation of industrial symbiosis relationships in areas where this practice is not yet implemented but bring together a set of characteristics that reveal the potential for establishing synergy networks. Examples include studies of the development of industrial symbiosis carried out in Perth and Kinross, Scotland [43], Botoșani and Piatra Neamţ in Romania [44], and Konia, Liberia [45].

Although the potential for the application of industrial symbiosis is high, there are a number of constraints on its implementation. A lack of trust, uncertainty about the benefits, a lack of knowledge of the concept of industrial symbiosis, and a lack of information sharing $[20,33,34,46-48]$ are the main factors that have been identified as restraining this process. However, there are also factors that are often referred to as drivers for the creation and development of industrial symbiosis networks, such as the need to reduce raw material and waste disposal costs and the potential generation of revenue [18,34,49-51]. In addition to these aspects, existing policies and legislation have also been identified as influencing industrial symbiosis practices. Regulatory pressure and landfill tax, which drive companies to find solutions for using resources more efficiently and reducing waste disposal [50,52], are examples of these. Policies and plans that aim to foster synergy networks, such as those in China $[23,25]$ and the United Kingdom [20], have greatly contributed to the spread of these practices. However, existing legislation can also restrict these practices, for example if it is unclear or very restrictive on the use of waste, and can thus create difficulties for companies with regard to the application of industrial symbiosis [53].

A literature review reveals that although there are many studies of the compilation and analysis of case studies relating to industrial symbiosis $[18,19,23,54-58]$, these focus on synergies that have already been implemented. Furthermore, although a study of the evolution of industrial symbiosis was carried out by Chertow and Park [59], with an analysis of the number of articles published and the countries that were the subject of the various publications, this work only included articles published until 2014. A comprehensive analysis of the cases of potential industrial symbiosis is still absent.

This article therefore aims to compile and analyse the various cases of potential industrial symbiosis in real contexts reported in the literature, and to highlight the margin of optimisation that is not being used. It also aims to identify and discuss the main drivers and barriers to the implementation of industrial symbiosis, as well as the various strategies for overcoming these barriers. To this end, the various cases are characterised and analysed by geographical location, type of economic activity, type of waste/by-product exchange, infrastructure sharing, and joint provision of services. Moreover, the methods employed in the different cases are analysed, as are the main environmental, economic, and social benefits that would be achieved if industrial symbiosis were to be realised. The cases of potential industrial symbiosis have been separated into those concerning the symbiosis between industries and those concerning the manufacture of new products and new uses for the different wastes enhanced by industrial symbiosis.

The rest of the article is organised as follows. Section 2 describes the methodology adopted for the research, selection, and analysis of publications, as well as the inclusion and exclusion criteria. 
Sections 3 and 4 contain the results and a discussion. Section 3 presents the results and an analysis of the cases of potential industrial symbiosis, in terms of the companies involved, the production of new products and new uses of waste. Section 4 discusses the main drivers, barriers, and strategies for overcoming these barriers to the creation of industrial symbiosis networks. Finally, Section 5 presents the main conclusions and discusses the limitations of this study and the scope for future research.

\section{Materials and Methods}

In order to fulfil the proposed objectives, a methodology was developed consisting of several stages, as illustrated in Figure 1. This methodology can be grouped into three main steps: a deep and systematic collection of the existing literature, the selection of publications and a content analysis.

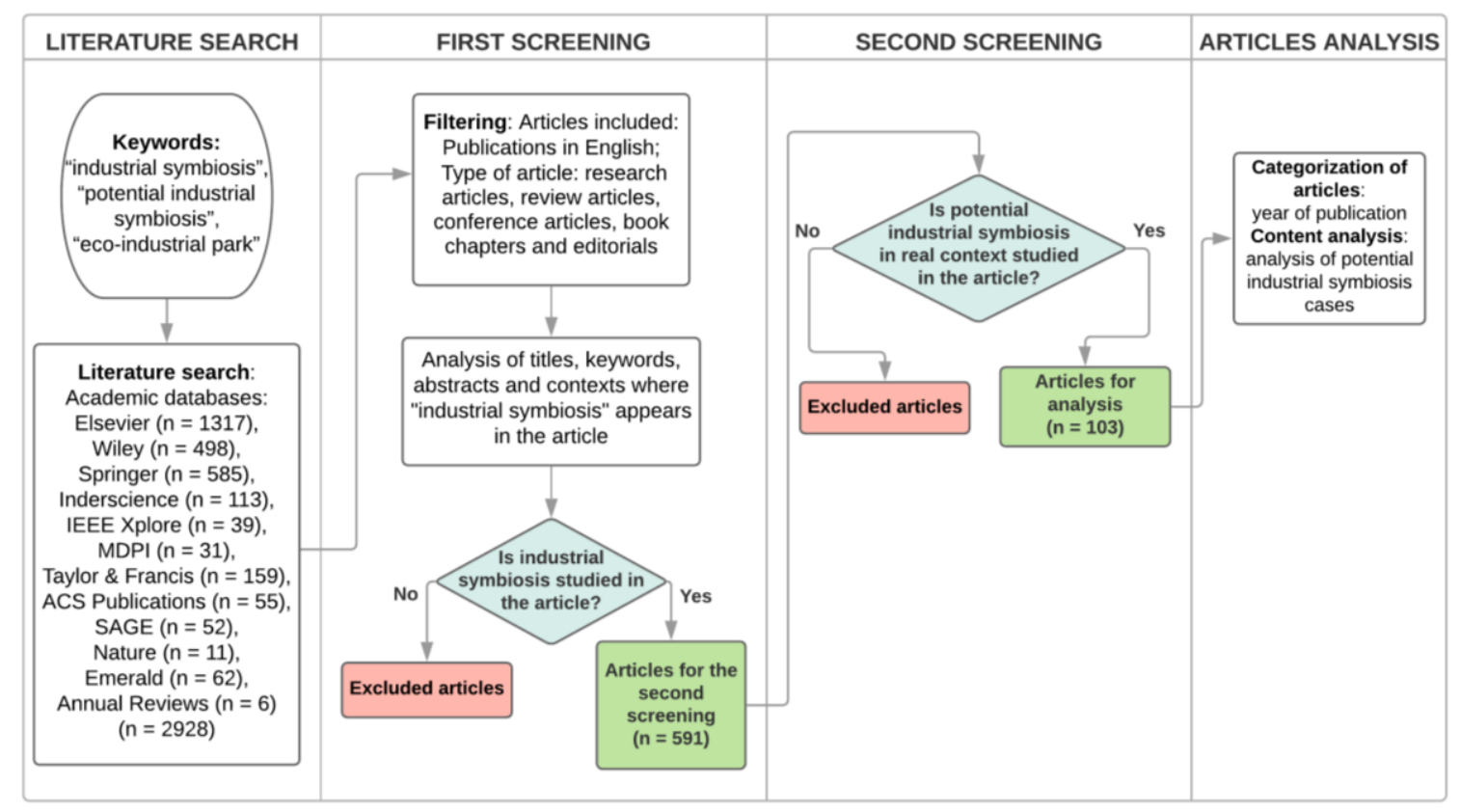

Figure 1. Flow diagram of literature search and screening.

To enable a systematic and thorough review of the existing literature, several steps were followed. The first was the choice of keywords. To avoid limiting the search and thus obtain a more comprehensive set of publications, the terms "industrial symbiosis", "potential industrial symbiosis", and "eco-industrial park" were combined. These were used to search for articles in databases with more publications in this area, such as, Elsevier, Wiley Online Library, Springer, MDPI, Inderscience Online, IEEE Xplore, Taylor \& Francis Online, ACS Publications, SAGE Journals, Nature Research, Emerald Insight, and Annual Reviews. In this research, no time interval was imposed, and the only exclusions were articles that were not written in English. The publications that resulted from this initial collection were submitted to a screening process in order to select the most relevant ones for the study. Titles, keywords, and abstracts were read, with the aim of selecting articles that focused mainly or significantly on industrial symbiosis. If there were any doubts about the inclusion of the articles, we analysed the frequency with which the keywords appeared throughout the publication and the context in which they were inserted in order to verify whether industrial symbiosis was the focus of the study or whether it only appeared as an example or to contextualise other concepts. This selection resulted in 591 publications, including research articles, review articles, conference articles, book chapters, and editorials. In our analysis, the references cited in these publications were used as secondary sources; however, this resulted in only a few articles, which may indicate the wide-ranging of the initial research. 
In the next step, the 591 articles on industrial symbiosis were screened with the aim of finding only the publications whose object was the study of potential industrial symbiosis in a real context. This resulted in 103 articles, and these made up the final body of articles for which a more detailed content analysis of potential industrial symbiosis was carried out. Of these 103 articles, 89 concerned industries and 14 concerned potential uses of industrial symbiosis to manufacture new products or use different wastes. A content analysis of all these articles was then conducted to gather and analyse information on potential industrial symbiosis, such as location, types of economic activities involved in potential synergies, types of waste/by-products, and the existence or otherwise of infrastructure sharing. We also analysed the methods employed in the different analyses, the main environmental, economic and social benefits, and the factors underlying the potential for creating industrial symbiosis, which may condition or favour it.

\section{Potential Industrial Symbiosis}

The results of the study are presented below and are structured according to the main themes that emerged from the research and analysis of publications on potential industrial symbiosis, namely its scope, evolution over time, geographical distribution, and cases of potential industrial symbiosis relating either to companies or to the production of new products or new uses of waste.

\subsection{Evolution of the Number of Published Articles}

Of the 591 articles on industrial symbiosis selected and analysed according to the selection criteria defined in Section 2, 103 related to potential industrial symbiosis, accounting for approximately $17 \%$ of the total. Although these articles on industrial symbiosis were published from 1995 onward, it was only around 2001 that articles on potential industrial symbiosis began to appear, as illustrated in Figure 2.

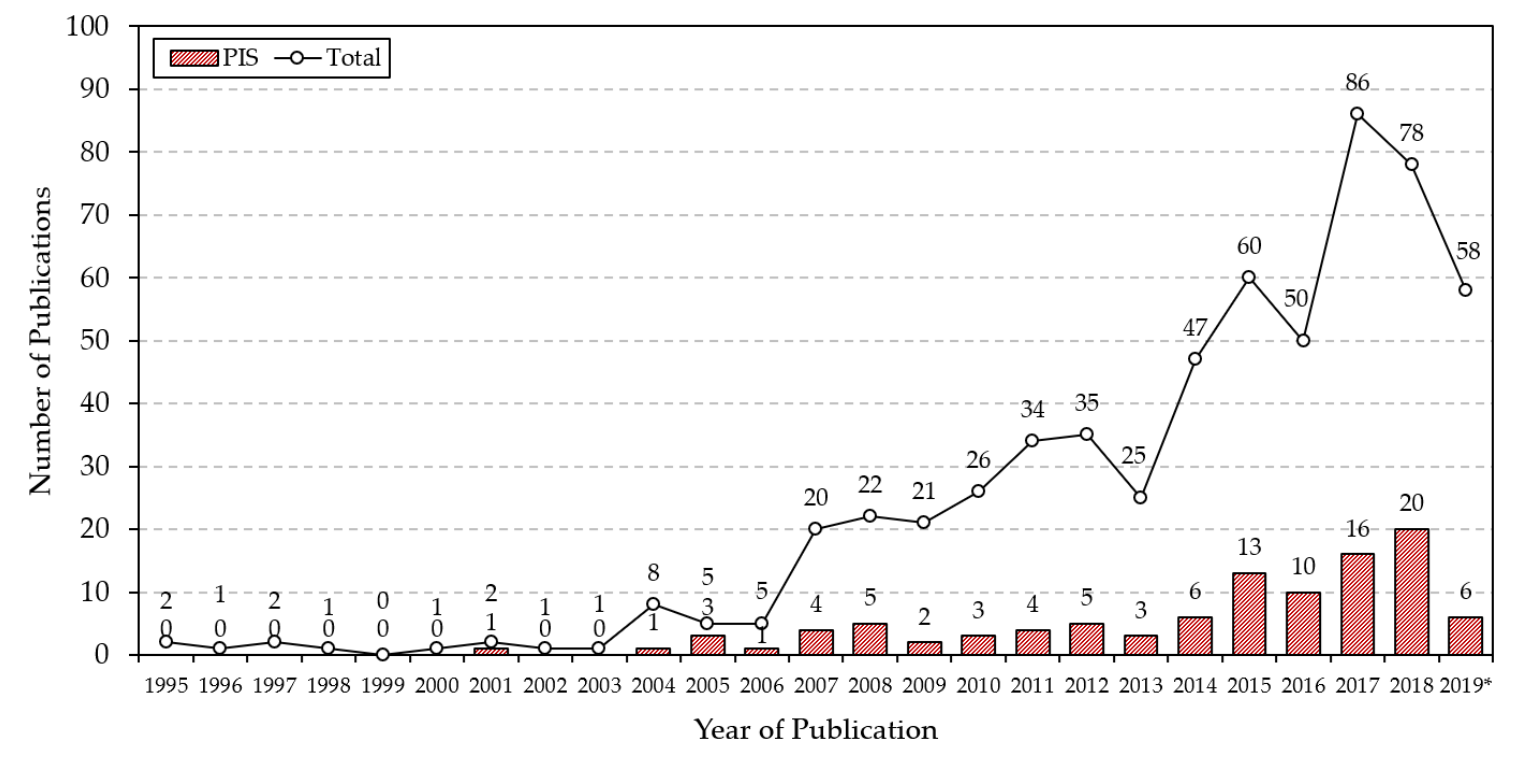

Figure 2. Number of publications on industrial symbiosis and potential industrial symbiosis (PIS) per year.

Figure 2 shows the growing evolution of the number of publications on industrial symbiosis. Although low numbers of studies were published during the early years, from 2007 onward, there was a growth in the number of publications, which continued over the following years. Despite these small numbers, publications on potential industrial symbiosis have also shown growth. The evolution of these publications essentially comprises two distinct periods. In the first, between 2001 and 2014, there was a greater oscillation between the number of publications and in which the growth of articles was not very significant. In the second, between 2015 and the current year, more pronounced growth 
could be seen, and whilst there was a drop in 2016, this was insignificant in light of the increase over the following years. Although this second period was shorter in terms of years, the proportion of publications was clearly higher than those in the first and accounted for $63 \%$ of the total number of publications. This increase coincided with the increase in publications on industrial symbiosis, and although it began to grow more significantly from 2007 onward, it was from 2014 onward that it began to obtain greater expression, revealing the growing scientific interest in this issue and the recognition of its potential to achieve sustainability in terms of its environmental, economic, and social aspects.

The proportion of the articles on potential industrial symbiosis in relation to the total number of publications on industrial symbiosis did not show significant variation over the years, except for 2001 and 2005, in which these articles made up 50\% and 60\% of the total number of publications, respectively. Three periods are of note, due to the fact that the values were very close in consecutive years - the period between 2006 and 2008, with an average of $20 \%$ of the total number of publications on potential industrial symbiosis; the period between 2009 and 2014, with an average of $12 \%$; and the period between 2015 and 2018, with an average of 21\%. Most of these 103 publications (about 84\%) relate to research articles, while $12 \%$ are conference papers, and the remaining $4 \%$ are book chapters.

\subsection{Geographic Distribution}

The study of potential industrial symbiosis has shown great diversity with regard to geographical location; it has been studied in 31 different countries, revealing the great potential of this practice both in developed countries and in countries with emergent economies, as illustrated in Figure 3. Europe leads in terms of the number of publications on potential industrial symbiosis, with 48 articles, corresponding to approximately $53 \%$ of the total published. It is followed by Asia, with 26 publications, corresponding to $29 \%$ of the total, and North America, South America, and Oceania, with six, four, and four publications, respectively, corresponding to $7 \%, 4 \%$, and $4 \%$ of the total. With three publications, equivalent to $3 \%$ of the total, Africa has the fewest studies of potential industrial symbiosis. This distribution is very different from that presented for industrial symbiosis publications [59]; here, China very significantly predominates in terms of publications, followed by the US and Australia.

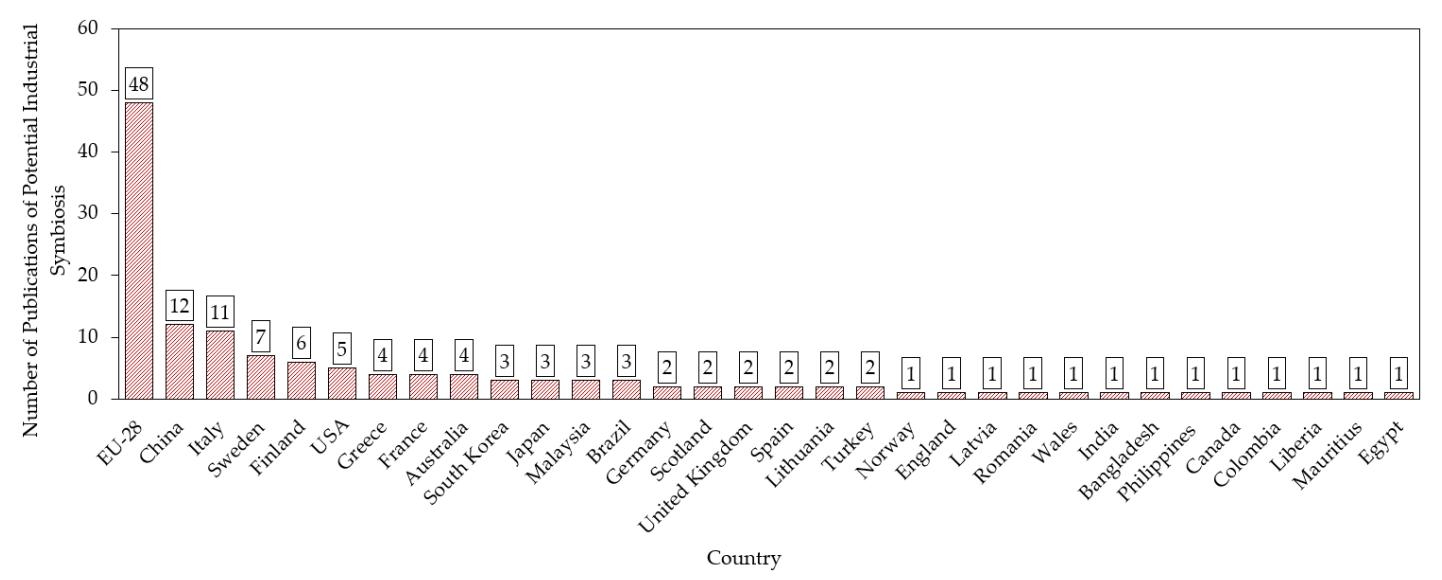

Figure 3. Distribution of the number of published studies on potential industrial symbiosis by country.

The European countries in which most case studies of potential industrial symbiosis were carried out were Italy, Sweden, and Finland, with 11, seven, and six articles, respectively. All cases in Sweden were related to the study of potential industrial symbiosis between industries, while those in Italy and Finland focused both on synergies between industries and on the investigation of waste and new products fostered by industrial symbiosis.

Of the eight countries in Asia with studies of potential industrial symbiosis, most related to China, with approximately $46 \%$ of the total for Asia. 
The US occupies the fifth place on the list of countries with articles published on potential industrial symbiosis, with three articles focusing on the synergy between industries and two more on the study of new uses for waste produced by the automobile industry. This figure is still low compared to the countries with the most publications, which is also true for case studies of industrial symbiosis-although the USA occupies second place on this list, the difference between the number of articles published compared to China, which ranks first, is very significant [19]. While some incentive measures have been applied to create synergies, such as an Environmental Protection Agency-funded project to identify possible synergies in six counties in North Carolina [60], they have not had a major impact on the increase in cases of symbiosis, and even existing studies of potential industrial symbiosis between industries date back many years.

In recent years, studies have been carried out to analyse the implementation of industrial symbiosis practices in developing countries such as the Philippines, Liberia, India, Bangladesh, Colombia, Mauritius, and Egypt. While these countries have little in the way of a tradition of synergy practices between companies and the number of published case studies is still small [19], the important role of industrial symbiosis is recognised as a means to enhance the development of these regions $[34,45,61]$.

\subsection{Cases of Potential Industrial Symbiosis}

Although industrial symbiosis is well established in many countries, there are still many possibilities for creating and developing new industrial symbioses. The numerous studies that have proposed and evaluated new synergy networks are examples of this. In places where there is already industrial symbiosis, the process of creating new relationships is facilitated, since there are already relationships of trust between the actors and the benefits offered by this practice are well known; however, this is not an essential factor. In places where there is no synergy, factors such as the location, the waste generated, or the nature of the industries can drive the creation of symbiosis relationships. Moreover, this potential is not bound to a particular region, country, type of activity, or number of entities (NE) involved, as proven in the many studies that have been performed to evaluate the creation of new industrial symbioses (shown in Table 1). This table summarises the main characteristics of the various cases of potential industrial symbiosis that have been published (Table A1 in Appendix A provides more details of these cases). By analysing Table A1, it is possible to verify the huge untapped potential and the huge diversity of opportunities for the development of industrial symbiosis. These cases are characterised by the location, number of entities involved (NE), type of economic activity, waste/by-product exchange, sharing of infrastructure, joint provision of services, methods used in the study, and assessment of the potential of industrial symbiosis. The various economic activities are grouped into sections, which are defined according to the International Standard Industrial Classification of All Economic Activities, Revision 4 (ISIC, Rev.4). Of the 21 sections defined in the ISIC, 16 are relevant to the various cases of potential industrial symbiosis. In Table 1, the section designations are more concisely defined. The different streams of waste exchanged in these cases are grouped into types, such as organic (e.g. food and food processing wastes, biomass, livestock and fisheries wastes); plastics and rubber; wood; metallic; non-metallic (e.g. glass, waste from construction and demolition, lime-based waste), paper, waste heat and steam; ash, water, and wastewater; chemicals; sludge; waste oil; and others (e.g. textile waste). 
Table 1. Potential industrial symbiosis applications and analysis studies.

\begin{tabular}{|c|c|c|c|c|c|c|c|c|}
\hline Country & Location/Region & $\mathrm{NE}^{1}$ & Activity & Waste/By-Products & $\begin{array}{c}\text { Infrastructure } \\
\text { Sharing/Joint } \\
\text { Provision of Services }\end{array}$ & Method & $\begin{array}{l}\text { Publication } \\
\text { Year }\end{array}$ & Refs. \\
\hline \multicolumn{9}{|c|}{ Europe } \\
\hline \multirow{10}{*}{ Italy } & Murano & & Manufacturing & Chemicals & Water treatment & $\begin{array}{l}\text { BATTER tool, direct } \\
\text { measurements }\end{array}$ & 2007 & [62] \\
\hline & $\begin{array}{c}\text { Brancaccio, } \\
\text { Carini, and } \\
\text { Termini Imerese }\end{array}$ & & Manufacturing & Plastics and rubber & & $\begin{array}{l}\text { Questionnaire and } \\
\text { interviews, life cycle } \\
\text { assessment }\end{array}$ & 2010 & [63] \\
\hline & $\begin{array}{l}\text { Val di Sangro } \\
\text { Industrial Area }\end{array}$ & 19 & Manufacturing & & $\begin{array}{l}\text { Collective } \\
\text { management of } \\
\text { scraps }\end{array}$ & $\begin{array}{c}\text { Questionnaires, } \\
\text { interviews, site visits, and } \\
\text { focus groups }\end{array}$ & 2014 & [64] \\
\hline & Fucino upland & & Agriculture and manufacturing & $\begin{array}{l}\text { Paper, plastics and } \\
\text { rubber, and wood }\end{array}$ & $\begin{array}{l}\text { Common local } \\
\text { recycling platform }\end{array}$ & $\begin{array}{l}\text { On-site survey and } \\
\text { interviews. }\end{array}$ & 2015 & [65] \\
\hline & Emilia-Romagna & & Agriculture and manufacturing & $\begin{array}{l}\text { Organic, sludge, paper, } \\
\text { non-metallic, wood, and } \\
\text { others }\end{array}$ & & $\begin{array}{c}\text { Interviews, guided } \\
\text { collective discussion, } \\
\text { visits to laboratories, and } \\
\text { conferences }\end{array}$ & 2015 & [53] \\
\hline & $\begin{array}{l}\text { Catania and } \\
\text { Siracusa } \\
\text { districts }\end{array}$ & & $\begin{array}{l}\text { Agriculture, manufacturing, } \\
\text { energy, water and waste, } \\
\text { construction, sale and repair, } \\
\text { transportation and storage, } \\
\text { information and communication, } \\
\text { professional and scientific } \\
\text { activities, administrative and } \\
\text { support service, education, } \\
\text { human health and social work, } \\
\text { and other service activities }\end{array}$ & $\begin{array}{l}\text { Water and wastewater, } \\
\text { organic, sludge, wood, } \\
\text { metallic, waste oil, } \\
\text { plastics and rubber, } \\
\text { chemicals, non-metallic, } \\
\text { and paper }\end{array}$ & $\begin{array}{l}\text { Energy, equipment, } \\
\text { expertise, and } \\
\text { services }\end{array}$ & $\begin{array}{l}\text { Invitation emails and } \\
\text { phone calls, meeting } \\
\text { tables }\end{array}$ & 2016 & {$[66]$} \\
\hline & Brescia & 12 & $\begin{array}{l}\text { Manufacturing, energy, and } \\
\text { public administration }\end{array}$ & $\begin{array}{l}\text { Metallic, wood, sludge, } \\
\text { and waste heat and steam }\end{array}$ & & SWOT analysis & 2017 & [67] \\
\hline & Brescia & 2 & Agriculture and manufacturing & Chemicals & & Economic model & 2018 & [35] \\
\hline & $\begin{array}{l}\text { Province of } \\
\text { Pescara }\end{array}$ & & $\begin{array}{l}\text { Agriculture, manufacturing, } \\
\text { water and waste, and } \\
\text { construction }\end{array}$ & $\begin{array}{c}\text { Organic, metallic, } \\
\text { non-metallic, paper, } \\
\text { plastics and rubber, waste } \\
\text { heat and steam, and } \\
\text { water and wastewater }\end{array}$ & & $\begin{array}{l}\text { Qualitative analysis and } \\
\text { critical analysis }\end{array}$ & 2017 & [11] \\
\hline & Marche Region & 3 & $\begin{array}{c}\text { Manufacturing and water and } \\
\text { waste }\end{array}$ & Plastics and rubber & & $\begin{array}{c}\text { Web platform, economic } \\
\text { assessments, life cycle } \\
\text { assessment }\end{array}$ & 2018 & [38] \\
\hline
\end{tabular}


Table 1. Cont

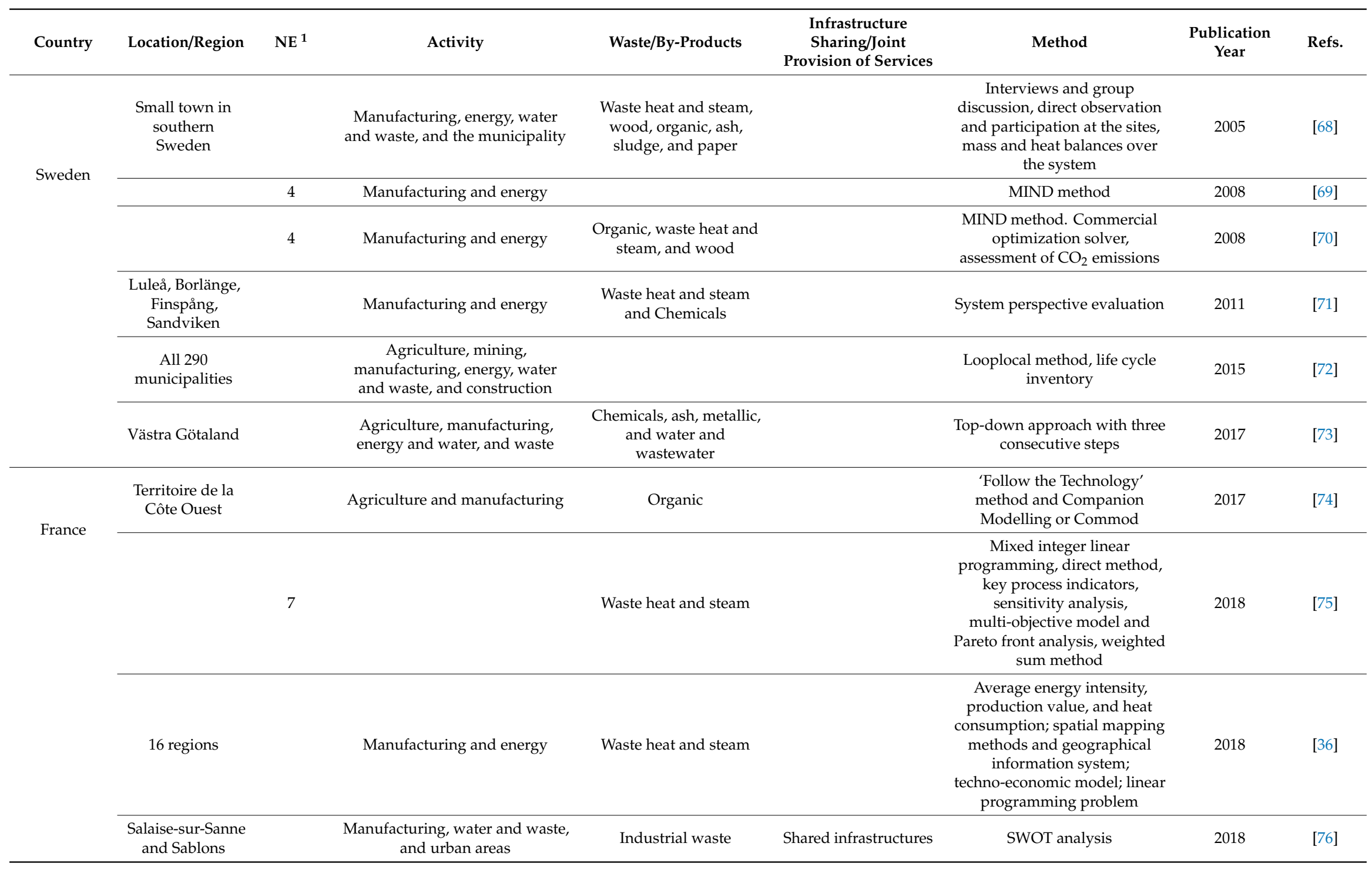


Table 1. Cont

\begin{tabular}{|c|c|c|c|c|c|c|c|c|}
\hline Country & Location/Region & $\mathrm{NE}^{1}$ & Activity & Waste/By-Products & $\begin{array}{c}\text { Infrastructure } \\
\text { Sharing/Joint } \\
\text { Provision of Services }\end{array}$ & Method & $\begin{array}{l}\text { Publication } \\
\text { Year }\end{array}$ & Refs. \\
\hline \multirow{3}{*}{ Finland } & Oulu & & Manufacturing & Metallic, ash, and others & & Literature review & 2010 & [77] \\
\hline & & & $\begin{array}{l}\text { Agriculture, manufacturing, } \\
\text { water and waste, and } \\
\text { municipality }\end{array}$ & Sludge and organic & & $\begin{array}{c}\text { Interviews, collaborative } \\
\text { research approach, replication } \\
\text { approach }\end{array}$ & 2015 & [78] \\
\hline & & & Agriculture and manufacturing & Organic & & Survey & 2018 & [79] \\
\hline \multirow[t]{3}{*}{ Greece } & Viotia & & Manufacturing & Metallic & & $\begin{array}{c}\text { Ontology engineering } \\
\text { approach-eSymbiosis; metrics } \\
\text { for industrial symbiosis } \\
\text { benefits }\end{array}$ & 2015 & [80] \\
\hline & Pili & & $\begin{array}{l}\text { Manufacturing, energy, and } \\
\text { water and waste }\end{array}$ & Wood, ash, and organic & Utility sharing & $\begin{array}{l}\text { Methodology to determine the } \\
\text { most appropriate location and } \\
\text { bioclimatic criteria }\end{array}$ & 2017 & [81] \\
\hline & Achaia & & Manufacturing & $\begin{array}{l}\text { Water and wastewater } \\
\text { and others }\end{array}$ & & Interviews and visits & 2017 & [82] \\
\hline \multirow[t]{2}{*}{ Germany } & Rhine-Neckar & & & & $\begin{array}{l}\text { Network structure, } \\
\text { waste software, and } \\
\text { intranet platform }\end{array}$ & On-site surveys & 2004 & [83] \\
\hline & $\begin{array}{l}\text { Central } \\
\text { Germany }\end{array}$ & & $\begin{array}{l}\text { (i) Manufacturing; (ii) } \\
\text { manufacturing and energy; (iii) } \\
\text { manufacturing and energy }\end{array}$ & $\begin{array}{l}\text { (i) Wood; (ii) wood and } \\
\text { organic; (iii) wood }\end{array}$ & & $\begin{array}{l}\text { Communications and site } \\
\text { visits; life cycle assessment and } \\
\text { CML } 2013 \text { method }\end{array}$ & 2018 & [84] \\
\hline \multirow[t]{2}{*}{ Scotland } & $\begin{array}{l}\text { Perth and } \\
\text { Kinross }\end{array}$ & & Manufacturing and energy & Wood & & $\begin{array}{l}\text { Questionnaires and focus } \\
\text { groups }\end{array}$ & 2007 & [85] \\
\hline & $\begin{array}{l}\text { Perth and } \\
\text { Kinross }\end{array}$ & & $\begin{array}{c}\text { Agriculture, manufacturing, and } \\
\text { energy }\end{array}$ & Wood & & $\begin{array}{l}\text { Questionnaire survey and an } \\
\text { attitude survey }\end{array}$ & 2007 & [43] \\
\hline \multirow[t]{2}{*}{ Spain } & Besaya & 80 & $\begin{array}{l}\text { Manufacturing, construction, } \\
\text { sale and repair, and } \\
\text { transportation and storage }\end{array}$ & $\begin{array}{l}\text { Waste oil, metallic, } \\
\text { non-metallic, plastics and } \\
\text { rubber, wood, waste oil, } \\
\text { paper, organic, and others }\end{array}$ & $\begin{array}{l}\text { Joint waste } \\
\text { management }\end{array}$ & Questionnaires and visits & 2015 & [86] \\
\hline & $\begin{array}{c}\text { Cartes, } \\
\text { Cantabria } \\
\text { autonomous } \\
\text { community }\end{array}$ & 25 & Manufacturing and construction & Organic, paper, etc. & $\begin{array}{l}\text { Service or } \\
\text { infrastructure }\end{array}$ & $\begin{array}{l}\text { Georeferencing, geographic } \\
\text { information systems, and } \\
\text { application programming } \\
\text { interface; SymbioSyS tool }\end{array}$ & 2017 & [87] \\
\hline
\end{tabular}


Table 1. Cont

\begin{tabular}{|c|c|c|c|c|c|c|c|c|}
\hline Country & Location/Region & $\mathrm{NE}^{1}$ & Activity & Waste/By-Products & $\begin{array}{c}\text { Infrastructure } \\
\text { Sharing/Joint } \\
\text { Provision of Services }\end{array}$ & Method & $\begin{array}{l}\text { Publication } \\
\quad \text { Year }\end{array}$ & Refs. \\
\hline \multirow[t]{2}{*}{ Lithuania } & Jonava & & $\begin{array}{l}\text { Agriculture, manufacturing, } \\
\text { water and waste, and } \\
\text { administrative and support } \\
\text { service }\end{array}$ & $\begin{array}{l}\text { Waste heat and steam, } \\
\text { organic, and sludge }\end{array}$ & & $\begin{array}{l}\text { Material flow analysis; } \\
\text { material, energy and fuel } \\
\text { balances; evaluation of } \\
\text { environmental indicators and } \\
\text { comparative analysis. } \\
\text { Feasibility analysis }\end{array}$ & 2016 & [88] \\
\hline & & & Agriculture and manufacturing & Organic & & Indicators & 2018 & [89] \\
\hline $\begin{array}{l}\text { United } \\
\text { Kingdom }\end{array}$ & & & Agriculture and manufacturing & Organic and others & & & 2008 & [90] \\
\hline Norway & Mongstad & 6 & $\begin{array}{c}\text { Agriculture, manufacturing, and } \\
\text { energy }\end{array}$ & $\begin{array}{l}\text { Chemicals and waste } \\
\text { heat and steam }\end{array}$ & & $\begin{array}{l}\text { Mass and energy balance } \\
\text { assessment, material and } \\
\text { energy flow analysis, carbon } \\
\text { and hydrogen flow analysis, } \\
\mathrm{CO}_{2} \text { emission evaluation, and } \\
\text { sensitivity analysis; hierarchy } \\
\text { analysis method }\end{array}$ & 2008 & [91] \\
\hline England & Five areas & & & & Utilities-sharing & $\begin{array}{l}\text { Habitat suitability mapping, } \\
\text { and multi-criteria-evaluation } \\
\text { mapping; sensitivity analysis }\end{array}$ & 2012 & [92] \\
\hline $\begin{array}{l}\text { Finland and } \\
\text { Sweden }\end{array}$ & Gulf of Bothnia & 7 & Manufacturing & Metallic & & $\begin{array}{l}\text { Strengths and weaknesses } \\
\text { assessment and common pool } \\
\text { resource management analysis }\end{array}$ & 2012 & [93] \\
\hline Latvia & & 2 & Manufacturing and energy & Organic & & $\begin{array}{l}\text { Site visits, cumulative intensity } \\
\text { indicator of a considered factor }\end{array}$ & 2015 & [94] \\
\hline $\begin{array}{c}\text { European } \\
\text { country }\end{array}$ & & & Agriculture and Manufacturing & $\begin{array}{c}\text { Chemicals and Water and } \\
\text { wastewater }\end{array}$ & & Concept analysis & 2015 & [95] \\
\hline Romania & $\begin{array}{l}\text { Botosani and } \\
\text { Neamt }\end{array}$ & & $\begin{array}{l}\text { Agriculture, manufacturing, } \\
\text { energy, water and waste, } \\
\text { construction, sale and repair, } \\
\text { accommodation and food, and } \\
\text { administrative and support } \\
\text { service }\end{array}$ & Chemicals & $\begin{array}{l}\text { Infrastructure for } \\
\text { utilities and supply } \\
\text { process optimization }\end{array}$ & Interviews & 2017 & [44] \\
\hline
\end{tabular}


Table 1. Cont.

\begin{tabular}{|c|c|c|c|c|c|c|c|c|}
\hline Country & Location/Region & $\mathrm{NE}^{1}$ & Activity & Waste/By-Products & $\begin{array}{c}\text { Infrastructure } \\
\text { Sharing/Joint } \\
\text { Provision of Services }\end{array}$ & Method & $\begin{array}{l}\text { Publication } \\
\text { Year }\end{array}$ & Refs. \\
\hline \multicolumn{9}{|c|}{ Asia } \\
\hline \multirow{8}{*}{ China } & Handan & & $\begin{array}{c}\text { Agriculture, } \\
\text { manufacturing, and } \\
\text { energy }\end{array}$ & $\begin{array}{l}\text { Ash, water and } \\
\text { wastewater, plastics and } \\
\text { rubber, waste heat and } \\
\text { steam, metallic, and } \\
\text { others }\end{array}$ & & & 2009 & [96] \\
\hline & $\begin{array}{l}\text { Shanghai City } \\
\text { and Jiangsu } \\
\text { Province }\end{array}$ & & $\begin{array}{l}\text { Manufacturing and } \\
\text { urban areas }\end{array}$ & $\begin{array}{l}\text { Plastics and rubber, } \\
\text { organic, and others }\end{array}$ & & $\begin{array}{l}\text { Divisia analysis, energy demand analysis, and } \\
\text { regression analysis }\end{array}$ & 2011 & [97] \\
\hline & Jinqiao & & $\begin{array}{l}\text { Manufacturing, energy, } \\
\text { and water and waste }\end{array}$ & Sludge and waste oil & & $\begin{array}{l}\text { Experiments in a laboratory, life cycle } \\
\text { assessment, total environmental impact }\end{array}$ & 2011 & [98] \\
\hline & Yunfu & 3 & $\begin{array}{c}\text { Manufacturing and } \\
\text { energy }\end{array}$ & $\begin{array}{l}\text { Chemicals and waste } \\
\text { heat and steam }\end{array}$ & & Production cost and sale revenue analysis & 2011 & [99] \\
\hline & Shenyang & & $\begin{array}{l}\text { Manufacturing and } \\
\text { transportation and } \\
\text { storage }\end{array}$ & & & $\begin{array}{l}\text { Coefficient of industrial agglomeration } \\
\text { degree, Space Gini coefficient and Hector } \\
\text { Fanta coefficient, logistic model, index of } \\
\text { competitive analysis, expert evaluation } \\
\text { method relational degree taxis }\end{array}$ & 2012 & [100] \\
\hline & Guiyang & & $\begin{array}{l}\text { Manufacturing, energy, } \\
\text { and commercial and } \\
\text { residential area }\end{array}$ & $\begin{array}{l}\text { Metallic, plastics and } \\
\text { rubber, ash, waste heat } \\
\text { and steam, and others }\end{array}$ & & $\begin{array}{l}\text { Questionnaires, material flow analysis, } \\
\text { environmental benefit evaluation and } \mathrm{CO}_{2} \\
\text { emission reduction, cost reduction }\end{array}$ & 2015 & [39] \\
\hline & Guiyang & & $\begin{array}{l}\text { Manufacturing, energy, } \\
\text { and commercial and } \\
\text { residential area }\end{array}$ & $\begin{array}{l}\text { Metallic, plastics and } \\
\text { rubber, ash, waste heat } \\
\text { and steam, and others }\end{array}$ & & $\begin{array}{l}\text { Questionnaires, material/energy flow analysis, } \\
\text { process life cycle assessment, avoided } \\
\text { consumptions and emissions, } \mathrm{CO}_{2} \text { emission } \\
\text { reduction, hybrid physical input and } \\
\text { monetary output model, hybrid life cycle } \\
\text { assessment model integrating both process } \\
\text { life cycle assessment and input-output model, } \\
\text { life cycle emissions change, scenario analysis }\end{array}$ & 2016 & [9] \\
\hline & $\begin{array}{l}\text { Hangu, Tanggu, } \\
\text { and Dagang } \\
\text { Districts }\end{array}$ & & $\begin{array}{c}\text { Agriculture, } \\
\text { manufacturing, and } \\
\text { energy }\end{array}$ & $\begin{array}{l}\text { Water and wastewater } \\
\text { and others }\end{array}$ & & $\begin{array}{l}\text { Satellite images analysis, geospatial data } \\
\text { processing and analysis software, manual } \\
\text { visual interpretation and landscape type } \\
\text { classification system }\end{array}$ & 2015 & [101] \\
\hline
\end{tabular}


Table 1. Cont.

\begin{tabular}{|c|c|c|c|c|c|c|c|c|}
\hline Country & Location/Region & $\mathrm{NE}^{1}$ & Activity & Waste/By-Products & $\begin{array}{c}\text { Infrastructure } \\
\text { Sharing/Joint } \\
\text { Provision of Services }\end{array}$ & Method & $\begin{array}{l}\text { Publication } \\
\text { Year }\end{array}$ & Refs. \\
\hline & Liuzhou & 5 & $\begin{array}{l}\text { Manufacturing, energy, } \\
\text { and communities }\end{array}$ & $\begin{array}{l}\text { Plastics and rubber, ash, } \\
\text { and others }\end{array}$ & & $\begin{array}{l}\text { Questionnaires, onsite survey, urban level } \\
\text { hybrid physical input and monetary output } \\
\text { model, hybrid evaluation model integrating } \\
\text { process-based life cycle assessment and } \\
\text { input-output analysis, calculation of increased } \\
\text { or avoided consumption, trade-off emission, } \\
\text { scenarios design }\end{array}$ & 2017 & [37] \\
\hline & Liuzhou & & $\begin{array}{l}\text { Manufacturing, energy, } \\
\text { and communities }\end{array}$ & $\begin{array}{l}\text { Chemicals, waste heat } \\
\text { and steam, plastics and } \\
\text { rubber, and ash }\end{array}$ & & $\begin{array}{l}\text { Onsite survey, analytical approach integrating } \\
\text { material flows analysis, and emergy } \\
\text { evaluation model, avoided consumption and } \\
\text { emissions and } \mathrm{CO}_{2} \text { emission reduction, } \\
\text { emergy evaluation index and dilution emergy }\end{array}$ & 2017 & [10] \\
\hline & $\begin{array}{l}280 \text { proper cities } \\
\text { and } 357 \\
\text { county-level } \\
\text { cities }\end{array}$ & & $\begin{array}{l}\text { Manufacturing, energy, } \\
\text { and residential and } \\
\text { commercial buildings }\end{array}$ & $\begin{array}{l}\text { Waste heat and steam, } \\
\text { ash, and metallic }\end{array}$ & & $\begin{array}{l}\text { Cross-sectoral symbiosis modelling; energy } \\
\text { cascade algorithms; material-exchange } \\
\text { algorithms; estimating reductions in fuel use, } \\
\mathrm{CO}_{2} \text { and PM2.5 emissions, life-cycle analysis, } \\
\text { and national-economy-wide economic input } \\
\text { output-based life-cycle analysis; PM2.5 } \\
\text { pollution and health benefit calculations and } \\
\text { AERMOD atmospheric dispersion modelling } \\
\text { system }\end{array}$ & 2017 & [102] \\
\hline & Wuhan & & $\begin{array}{c}\text { Agriculture, } \\
\text { manufacturing, and } \\
\text { water and waste }\end{array}$ & $\begin{array}{l}\text { Water and wastewater, } \\
\text { sludge, and paper }\end{array}$ & & $\begin{array}{l}\text { Integrated life cycle management assessment } \\
\text { method on the resource flows of industrial } \\
\text { ecosystem }\end{array}$ & 2019 & [103] \\
\hline \multirow[t]{3}{*}{ South Korea } & & & Manufacturing & Water and wastewater & & $\begin{array}{l}\text { Mathematical optimization model, general } \\
\text { algebraic modelling system software, life } \\
\text { cycle assessment and life cycle costing }\end{array}$ & 2010 & {$[104]$} \\
\hline & & & $\begin{array}{l}\text { (i) Manufacturing; (ii) } \\
\text { manufacturing and } \\
\text { urban area }\end{array}$ & $\begin{array}{l}\text { (i) Others; (ii) wood and } \\
\text { plastics and rubber }\end{array}$ & & $\begin{array}{l}\text { Interview, quantitative estimation of } \mathrm{CO}_{2} \\
\text { emissions, uncertainty analysis }\end{array}$ & 2015 & [105] \\
\hline & Ulsan & & $\begin{array}{l}\text { Manufacturing and/or } \\
\text { urban area }\end{array}$ & Waste heat and steam & & $\begin{array}{l}\text { Interviews, scenarios analysis, heat load } \\
\text { analysis procedure, } \mathrm{CO}_{2} \text { emission reductions, } \\
\text { fuel cost reduction }\end{array}$ & 2018 & [106] \\
\hline
\end{tabular}


Table 1. Cont.

\begin{tabular}{|c|c|c|c|c|c|c|c|c|}
\hline Country & Location/Region & $\mathrm{NE}^{1}$ & Activity & Waste/By-Products & $\begin{array}{c}\text { Infrastructure } \\
\text { Sharing/Joint } \\
\text { Provision of Services }\end{array}$ & Method & $\begin{array}{c}\text { Publication } \\
\text { Year }\end{array}$ & Refs. \\
\hline \multirow[t]{3}{*}{ Japan } & Shinchi Town & & $\begin{array}{l}\text { Manufacturing and } \\
\text { energy }\end{array}$ & Waste heat and steam & & $\begin{array}{l}\text { Technical and economic feasibility assessment, } \\
\text { sensitivity analysis, cost-benefit assessment } \\
\text { and spatial analysis; energy generation model; } \\
\text { energy distribution model; energy } \\
\text { consumption model }\end{array}$ & 2014 & [107] \\
\hline & Shinchi Town & & $\begin{array}{l}\text { Manufacturing, energy, } \\
\text { and urban area }\end{array}$ & Waste heat and steam & & $\begin{array}{l}\text { Model framework including energy system } \\
\text { design, land use scenario, inventory survey } \\
\text { and geographic analysis; district heating } \\
\text { network design and simulation; cost-benefit } \\
\text { assessment; sensitivity analysis; }\end{array}$ & 2018 & [13] \\
\hline & Tanegashima & & $\begin{array}{c}\text { Agriculture, } \\
\text { manufacturing, and } \\
\text { energy }\end{array}$ & $\begin{array}{l}\text { Waste heat and steam, } \\
\text { organic, and wood }\end{array}$ & & $\begin{array}{l}\text { interviews; scenario analysis, energy flow } \\
\text { analysis; greenhouse gas emissions based on } \\
\text { life cycle analysis }\end{array}$ & 2016 & [108] \\
\hline \multirow[t]{3}{*}{ Malaysia } & & 4 & $\begin{array}{l}\text { Manufacturing and } \\
\text { energy }\end{array}$ & Organic & & $\begin{array}{l}\text { Disjunctive fuzzy optimization approach; } \\
\text { overall degree of satisfaction, annual gross } \\
\text { profit, net present value, and payback period } \\
\text { of a processing plant }\end{array}$ & 2014 & [109] \\
\hline & & & Manufacturing & & $\begin{array}{l}\text { Cooperative safety } \\
\text { management }\end{array}$ & Interview & 2014 & [110] \\
\hline & Kedah & & $\begin{array}{l}\text { Manufacturing, energy, } \\
\text { and water and waste }\end{array}$ & $\begin{array}{l}\text { Chemicals, Plastics and } \\
\text { rubber, Water and } \\
\text { wastewater, and Sludge }\end{array}$ & Infrastructure sharing & $\begin{array}{l}\text { Questionnaires. SWOT analysis. Materials } \\
\text { Flow Analysis and the Input-Output data } \\
\text { based on previous Life Cycle Analysis data }\end{array}$ & 2017 & [111] \\
\hline \multirow[t]{2}{*}{ Turkey } & Gaziantep & & $\begin{array}{l}\text { Manufacturing, Energy } \\
\text { and Water and waste }\end{array}$ & $\begin{array}{l}\text { Organic, Plastics and } \\
\text { rubber, Sludge, } \\
\text { Chemicals, Non-metallic, } \\
\text { Waste heat and steam, } \\
\text { and Others }\end{array}$ & & $\begin{array}{l}\text { Industrial symbiosis match-making platform } \\
\text { (ESOTA®, Industrial Symbiosis Opportunity } \\
\text { Screening Tool). Visits and workshops }\end{array}$ & 2017 & [112] \\
\hline & Ankara & 10 & Manufacturing & Waste heat and steam & & $\begin{array}{l}\text { Tool for defining data about companies and } \\
\text { process, cleaner production potential and } \\
\text { costs and environmental impact graph of } \\
\text { processes. Analysis of mass balance and all } \\
\text { materials }\end{array}$ & 2018 & [113] \\
\hline India & Puducherry & & Manufacturing & & & $\begin{array}{l}\text { Survey method; trend analysis, causal chain } \\
\text { analysis, policy analysis, training needs } \\
\text { assessment, technology needs assessment, } \\
\text { and barrier analysis; content analysis; SWOT } \\
\text { analysis }\end{array}$ & 2015 & [114] \\
\hline
\end{tabular}


Table 1. Cont.

\begin{tabular}{|c|c|c|c|c|c|c|c|c|}
\hline Country & Location/Region & $\mathrm{NE}^{1}$ & Activity & Waste/By-Products & $\begin{array}{c}\text { Infrastructure } \\
\text { Sharing/Joint } \\
\text { Provision of Services }\end{array}$ & Method & $\begin{array}{c}\text { Publication } \\
\text { Year }\end{array}$ & Refs. \\
\hline Bangladesh & $\begin{array}{l}\text { Chittagong } \\
\text { Export } \\
\text { Processing Zone }\end{array}$ & & $\begin{array}{l}\text { Manufacturing, energy, } \\
\text { and water and waste }\end{array}$ & $\begin{array}{l}\text { Waste heat and steam, } \\
\text { water and wastewater, } \\
\text { and others }\end{array}$ & & $\begin{array}{c}\text { On-site energy audit and equipment/waste } \\
\text { emission survey, visits, input and output } \\
\text { analysis, feasibility analysis, business model } \\
\text { development }\end{array}$ & 2015 & [115] \\
\hline Philippines & Laguna & & & & & $\begin{array}{c}\text { questionnaires and survey, decision making } \\
\text { trial and evaluation laboratory }\end{array}$ & 2016 & [116] \\
\hline \multicolumn{9}{|c|}{ North America } \\
\hline \multirow[t]{3}{*}{ USA } & $\begin{array}{l}\text { Six counties, } \\
\text { North Carolina }\end{array}$ & 87 & $\begin{array}{l}\text { Manufacturing and } \\
\text { water and waste }\end{array}$ & $\begin{array}{l}\text { Chemicals, plastics and } \\
\text { rubber, wood, ash, } \\
\text { metallic, non-metallic, } \\
\text { organic, waste heat and } \\
\text { steam, water and } \\
\text { wastewater, and others }\end{array}$ & & $\begin{array}{l}\text { telephone calls, interviews and site visits, } \\
\text { discussions and brainstorming sessions, } \\
\text { geographic information system maps }\end{array}$ & 2001 & [60] \\
\hline & Texas & & $\begin{array}{l}\text { Manufacturing and } \\
\text { water and waste }\end{array}$ & $\begin{array}{l}\text { Commercial, industrial, } \\
\text { and municipal waste }\end{array}$ & & $\begin{array}{l}\text { Questionnaire survey, modified total design } \\
\text { method }\end{array}$ & 2005 & [117] \\
\hline & Pittsburgh & & $\begin{array}{l}\text { Manufacturing and } \\
\text { construction }\end{array}$ & Ash and others & & $\begin{array}{l}\text { Highway density map, road density. and total } \\
\text { highway density; optimization analysis; life } \\
\text { cycle analysis; transportation cost analysis }\end{array}$ & 2008 & [118] \\
\hline Canada & Ontario & & $\begin{array}{c}\text { Agriculture, } \\
\text { manufacturing, and } \\
\text { water and waste }\end{array}$ & $\begin{array}{l}\text { Non-metallic, chemicals, } \\
\text { and waste heat and steam }\end{array}$ & & Inputs and outputs analysis & 2009 & [119] \\
\hline \multicolumn{9}{|c|}{ South America } \\
\hline \multirow[t]{2}{*}{ Brazil } & & & $\begin{array}{c}\text { Agriculture and } \\
\text { manufacturing }\end{array}$ & Organic, ash, and others & & $\begin{array}{l}\text { Economic evaluation, environmental and } \\
\text { social analysis, emergy method }\end{array}$ & 2007 & [120] \\
\hline & $\begin{array}{l}\text { Norte } \\
\text { Fluminense } \\
\text { region }\end{array}$ & 14 & $\begin{array}{l}\text { Agriculture, } \\
\text { manufacturing, energy, } \\
\text { and water and waste }\end{array}$ & $\begin{array}{l}\text { Organic, chemicals, waste } \\
\text { oil, ash, and others }\end{array}$ & & $\begin{array}{c}\text { Interviews and visit; scenario analysis, mass } \\
\text { balance, synergy matrix, and material flow } \\
\text { analysis; environmental, social, and economic } \\
\text { indicators }\end{array}$ & 2018 & [121] \\
\hline Colombia & 15 towns & 34 & $\begin{array}{c}\text { Agriculture, } \\
\text { manufacturing, energy, } \\
\text { water and waste, } \\
\text { construction, sale and } \\
\text { repair, accommodation } \\
\text { and food, and } \\
\text { administrative and } \\
\text { support service }\end{array}$ & $\begin{array}{l}\text { Wood, plastics and } \\
\text { rubber, paper, organic, } \\
\text { non-metallic, sludge, } \\
\text { water and wastewater, } \\
\text { and others }\end{array}$ & Service sharing & $\begin{array}{l}\text { Workshops, observations, surveys, and } \\
\text { interviews }\end{array}$ & 2018 & [34] \\
\hline
\end{tabular}


Table 1. Cont.

\begin{tabular}{|c|c|c|c|c|c|c|c|c|}
\hline Country & Location/Region & $\mathrm{NE}^{1}$ & Activity & Waste/By-Products & $\begin{array}{c}\text { Infrastructure } \\
\text { Sharing/Joint } \\
\text { Provision of Services }\end{array}$ & Method & $\begin{array}{c}\text { Publication } \\
\text { Year }\end{array}$ & Refs. \\
\hline \multicolumn{9}{|c|}{ Africa } \\
\hline Liberia & Konia & & $\begin{array}{c}\text { Agriculture, } \\
\text { manufacturing, and } \\
\text { accommodation and } \\
\text { food }\end{array}$ & Organic and others & Fishponds & Interviews, optimization model & 2014 & [45] \\
\hline Mauritius & & & $\begin{array}{l}\text { Manufacturing and } \\
\text { water and waste }\end{array}$ & $\begin{array}{l}\text { Organic, sludge, metallic, } \\
\text { and others }\end{array}$ & & $\begin{array}{l}\text { Interviews and framework for adopting } \\
\text { industrial symbiosis }\end{array}$ & 2017 & [122] \\
\hline Egypt & Borg El-Arab & & $\begin{array}{c}\text { Agriculture and } \\
\text { manufacturing }\end{array}$ & $\begin{array}{l}\text { Organic, metallic, } \\
\text { non-metallic, paper, } \\
\text { plastics and rubber, } \\
\text { wood, and others }\end{array}$ & & Data from internal unpublished sources & 2018 & [61] \\
\hline \multicolumn{9}{|c|}{ Oceania } \\
\hline \multirow[t]{2}{*}{ Australia } & $\begin{array}{l}\text { New South } \\
\text { Wales }\end{array}$ & & $\begin{array}{l}\text { Mining, manufacturing, } \\
\text { and energy }\end{array}$ & $\begin{array}{l}\text { Chemicals, ash, metallic, } \\
\text { and others }\end{array}$ & & Aspen modelling & 2012 & [123] \\
\hline & Kwinana & 12 & $\begin{array}{l}\text { Manufacturing, energy, } \\
\text { water and waste, and } \\
\text { construction }\end{array}$ & Chemicals and others & & $\begin{array}{l}\text { Triple bottom-line perspective and } \\
\text { preliminary sustainability assessment }\end{array}$ & 2013 & [124] \\
\hline
\end{tabular}

${ }^{1}$ NE: Number of enterprises 
The cases compiled here are organised by region, and these are arranged into descending order based on the number of cases studied, i.e., Europe, Asia, North America, South America, Africa, and Oceania. Within each region, the various countries are also listed in descending order based on the number of cases studied, and within each country, the same process was carried out in ascending order based on the date of publication of the article.

In the following sections, the main characteristics of the cases of potential industrial symbiosis, the methods used in the analyses and the main potential benefits of these synergies are analysed and discussed.

\subsubsection{Level of Implementation}

Similar to industrial ecology and the circular economy, industrial symbiosis can be implemented at three levels: the micro, meso and macro levels [40,125-128]. These are related to the boundaries at which industrial symbiosis relationships develop, i.e., at company (micro) level; between businesses with geographic proximity, such as eco-industrial parks (meso level); and activities that are carried out at regional or national level (macro level). Table 2 illustrates the diversity of potential industrial symbiosis cases, shown in Table 1, for each level of implementation.

Table 2. Distribution of potential industrial symbiosis cases by level of implementation.

\begin{tabular}{|c|c|}
\hline Levels of Implementation & Potential Industrial Symbiosis Cases (Refs.) \\
\hline Meso & $\begin{array}{c}\text { Industrial park/eco-industrial park: }[75,76,87,91,98,104,110,114] \\
\text { business park: }[81] \text {; local industrial network: [64]; industrial districts } \\
\text { (companies with geographical proximity): [67]; nearby companies: } \\
{[35,36] \text {; clusters: }[73,107]}\end{array}$ \\
\hline Macro & $\begin{array}{c}\text { Region: }[43,53,66,80,83,93] \text {; region (residential, industrial, rural } \\
\text { dimensions): [11]; city (industrial park and urban area, industrial and } \\
\text { urban symbiosis): [9,37,39,106]; municipality: [72]; island: [74,122]; } \\
\text { agro-industrial symbiosis: [120]; automotive sector: [63] }\end{array}$ \\
\hline
\end{tabular}

\subsubsection{Industries Potentially Involved in Industrial Symbiosis}

The diversity of economic activities with the potential to become part of an industrial symbiosis network is very wide, as illustrated in Tables 1 and A1. Manufacturing, which comprises activities involving the transformation of materials into new products, is the predominant sector in these cases of potential industrial symbiosis, as shown in Figure 4. This figure represents the distribution by country of all the economic activities involved in the various cases, grouped into sections according to the format established in the International Standard Industrial Classification of All Economic Activities, Revision 4 (ISIC, Rev.4). Of the 21 sections defined in ISIC, 16 are relevant to the various cases studied, with manufacturing accounting for $63 \%$ of the total occurrences of all sections. Sections such as agriculture, forestry and fishing, electricity and water, and waste management and recycling are also among the most frequently seen.

Within the manufacturing sector, the most frequent economic activities in the cases of potential synergy involve chemical, iron and steel, pulp and paper, construction materials, and wood and wood products. While there are cases in which manufacturing is the only sector in the synergy network, such as the study conducted in the Val di Sangro Industrial Area in Italy [64] or in Achaia in Greece [82], most of the cases involve several different industries within the manufacturing sector and other entities in the network that carry out other types of activity. This diversity of sectors has been highlighted by some authors $[18,129]$ as being very important for the establishment of industrial symbiosis networks, as it widens the opportunities available. 


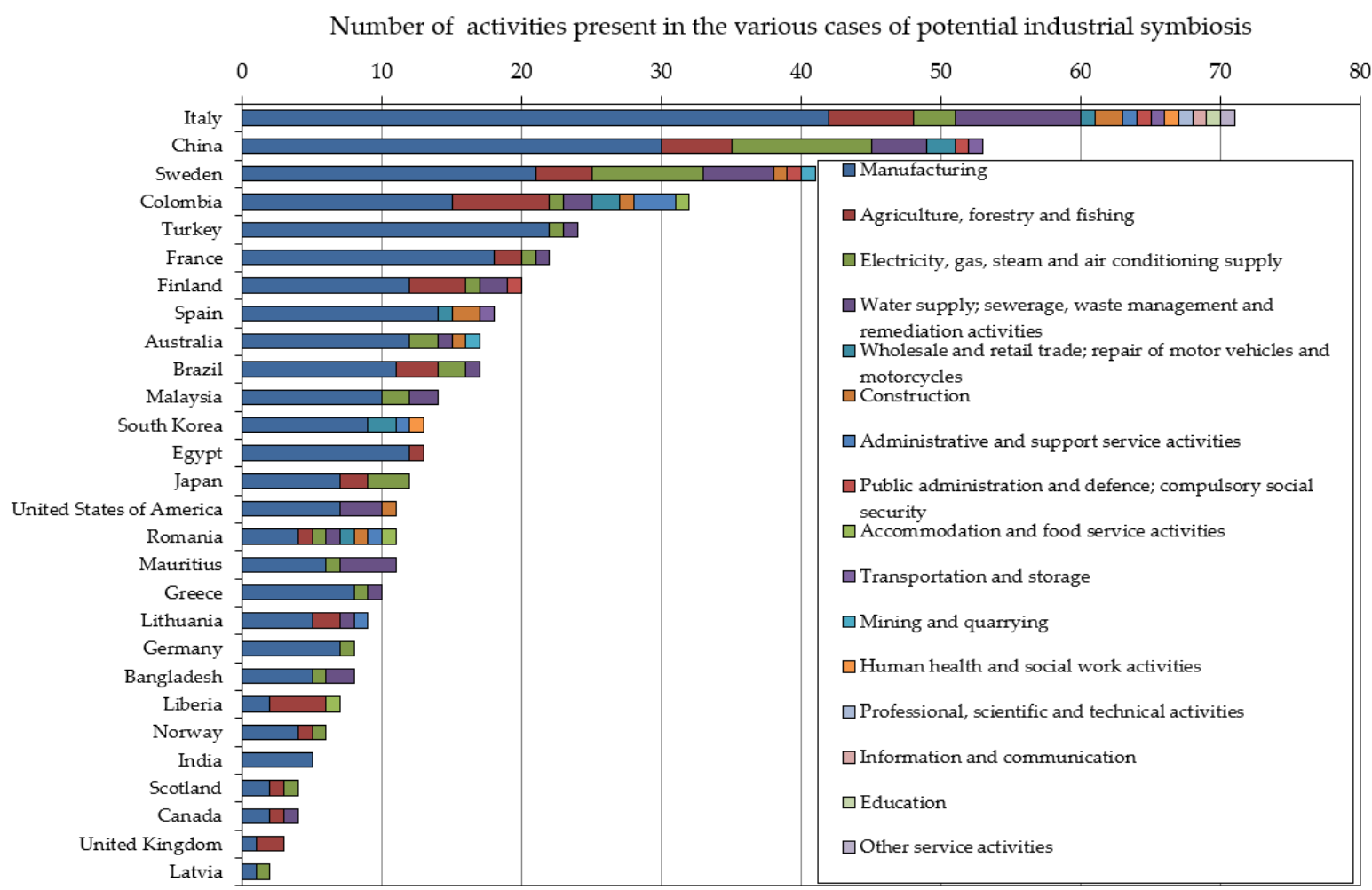

Figure 4. Distribution of the categories of economic activities existing in cases of potential industrial symbiosis by country.

\subsubsection{Types of Waste/By-Product Exchange, Infrastructure Sharing, and Joint Provision of Services}

The types of waste/by-product that have the potential to be used in the various cases of industrial symbiosis are very diverse, and are directly related to the nature of the economic activities that are carried out in the various networks of potential synergy. The most frequently reported wastes are organic (food and food processing wastes, biomass, livestock and fisheries wastes), plastics and rubber, wood, metallic, waste heat and steam, non-metallic (e.g. glass, waste from construction and demolition, lime-based waste), ash, water and wastewater, chemicals, sludge, and paper.

The sharing of infrastructure and the joint provision of services between companies has also been highlighted as a kind of symbiosis between entities, with potential to be developed and to provide benefits to the participants, albeit in lower numbers than for waste flow. The most frequently mentioned cases are facilities associated with the management and treatment of waste, water and recycling $[34,62,64,65,86]$. This type of scheme can assist companies in their waste management by freeing them of some of the costs associated with the storage and treatment of waste and by facilitating the direction of waste to various other companies. In addition to these aspects, the sharing of expertise, consultancy, equipment, logistics and transport, energy, and water supply infrastructure have also been identified as having potential to be established. Economic, environmental, and social benefits are identified as being likely to be attained if these types of sharing are established, such as cost savings in the construction of facilities [111], saving of resources used in waste treatment [62], reduction of inefficiencies [64], and job creation [65], and these can serve as drivers for the creation of new symbiosis relationships. Furthermore, the existence of shared and efficient infrastructures can foster new synergies between existing companies in the area and can also be an incentive for new companies to establish themselves in the region with the intention of being part of this symbiosis network. The sharing of services such as transport can also be an important factor in promoting symbiosis networks. Since most of the waste sold does not have a very high commercial value, any reduction in costs such as via 
the sharing of services can increase the potential economic benefits to the companies involved in these synergies and can foster the creation of new symbiosis relationships.

\subsubsection{Methods Used in the Analysis and Assessment of Potential Industrial Symbiosis}

In order to identify potential synergy relationships and assess the feasibility of implementing various cases of industrial symbiosis, several methods were used, as listed in Tables 1 and A1. The main objectives of this work were to study the best ways to establish synergy networks with regard to the most potential waste streams and the companies with the highest potential for integration and to assess the potential impacts that industrial symbiosis can have on the environment, the companies involved and the local population.

One of the first steps in the design and analysis of a potential synergy network is the collection of information and quantitative data. Various methods have been used for this, such as interviews $[44,65,78,82,106]$, questionnaires $[9,37,63,85,111]$, site visits $[64,84,86,112]$, and focus groups $[53,64,68,85]$.

To enable the realisation of industrial symbiosis networks, it is also essential to obtain knowledge not only of the possible participants but also of the numbers and types of waste/by-product available. Thus, in addition to meetings with local businesses that help foster possible relationships, as achieved in Emilia-Romagna, Italy [53], the Catania and Siracusa districts in Italy [66], and Colombia [34], the use of digital programs and platforms can also facilitate this interaction by building a common base with potential participants and waste and by optimising possible relationships. Examples of these are the development of a digital web platform for the electrical and electronic equipment sector [38], the Looplocal tool, which is useful in countries with geographically dispersed industries [72], the eSymbiosis multilingual service, implemented as an accessible web service [80], the SymbioSyS tool [87], and the ESOTA®platform, which is based on relationship mimicking [112].

One of the factors that can enhance the realisation of industrial symbiosis relationships is realisation of the potential benefits to businesses, not only the economic benefits, which are essential in encouraging companies to create synergies, but also the environmental and social benefits. While some of the studies carried out only a qualitative analysis, a significant proportion assessed at least one of these benefits. Of the three dimensions of sustainability, the environmental aspect was the most frequently discussed, and the most commonly applied method was the use of environmental indicators $[10,13,39,88,105]$. The reduction of carbon dioxide emissions was the most frequently addressed in the various analyses $[35,36,38,63,70,73,98]$, followed by quantification of savings in the consumption of resources such as energy, water, raw materials and fossil fuels $[9,39,63,88,95]$, and quantification of the reduction of waste sent to landfills $[9,34,39]$ resulting from the potential application of industrial symbiosis. Life cycle assessment $[9,38,63,84,98]$ was the method most commonly used to assess the environmental impact. The economic aspect, which was the second most frequently assessed, was measured using the life cycle costing method [104] and several metrics that primarily reflected reductions in raw material [39,60], fuel [13,106], energy consumption [35,36], waste disposal costs $[38,39]$, and increased revenue $[34,35,38,45,109]$. Job creation $[45,80,120,121]$ was the indicator most commonly used to assess the social benefits of realising potential industrial symbiosis relationships. The material flow analysis method $[9,10,39,88,111]$ has also been used several times to quantitatively assess potential industrial symbiosis. 
The environmental and economic components of sustainability have also been used to optimise and select the best potential symbiosis relationships. In order to compare industrial symbiosis with an equivalent system in which companies remain separate, several forms of synergy network integration have been evaluated and optimised based on their total costs [69] and carbon dioxide emissions [70] using the MIND method, an optimisation method based on mixed integer linear programming. Three models were developed using mixed integer linear programming to model and optimise waste streams in an industrial park in France with regard to cost and environmental impact [75].

SWOT analysis has also been used several times $[67,76,111,114]$ to study the internal and external factors in the potential application of industrial symbiosis networks.

\subsubsection{Potential Environmental, Economic, and Social Benefits}

An analysis of the various cases of potential industrial symbiosis leads to the conclusion that most of them intend to achieve environmental, economic and social benefits through these practices. Table 3 gives some examples of this. The environmental component was most frequently measured, largely due to international constraints on reducing greenhouse gas emissions, as well as national constraints on emission reductions and the amount of waste sent to landfills and incinerators. It is therefore important to ascertain whether these practices can be effective in meeting these limitations.

The economic component, which is often cited as a determinant factor in decisions by companies to establish symbiosis relations [34,130], was the second most frequently quantified component of sustainability. However, not all cases of industrial symbiosis have the potential to provide economic benefits to all participants, such as an example of symbiosis in a chemical industrial park in the west of Urumqi City, China. In this case, one of the companies did not receive economic benefits, largely due to the fact that the price of the raw material was lower than some types of industrial solid waste that were used for the production of bricks [130]. The environmental benefits, such as reduced consumption of natural resources and greenhouse gas emissions, justify the implementation of these networks of synergy, even without economic benefits, although, in these cases, it is important that local or national governments provide economic incentives that encourage companies to create these synergies.

It can therefore be concluded that the implementation of these cases of industrial symbiosis can provide a number of environmental, economic, and social benefits that translate into an efficient use of waste and resources. 
Table 3. Main environmental, economic and social benefits of potential industrial symbiosis.

\begin{tabular}{|c|c|c|c|}
\hline $\begin{array}{l}\text { Potential Industrial } \\
\text { Symbiosis (Refs.) }\end{array}$ & Environmental Benefits & Economic Benefits & Social Benefits \\
\hline [62] & $\begin{array}{l}\text { Improved air quality (emissions reduced up to } \\
65 \% \text { ), water quality (pollution reduced by } \\
20-30 \text { times), water and energy consumption } \\
\text { and } \mathrm{CO}_{2} \text { emissions (reduced up to } 60 \% \text { ) }\end{array}$ & & \\
\hline [69] & & $\begin{array}{l}\text { Reduction in system cost by } 17.6 \% \text {, increase in } \\
\text { electricity production by } 0.5 \% \text {, decrease in steam } \\
\text { discharge by } 78.0 \% \text {, decrease in waste heat } \\
\text { discharge by } 80.4 \% \text {, and increase in bark sales in } \\
72.8 \% \text { compared to the reference case }\end{array}$ & \\
\hline [85] & & & $\begin{array}{l}\text { On-site and off-site jobs creation, } \\
\text { contribution to the alleviation of } \\
\text { rural fuel poverty }\end{array}$ \\
\hline [63] & $\begin{array}{c}\text { Reduction of resource depletion, air emissions, } \\
\text { and landfilled wastes }\end{array}$ & $\begin{array}{l}\text { Costs of secondary polypropylene are reduced up } \\
\text { to a factor of 10, compared with virgin plastics; } \\
\text { reduction of waste costs; reduction of } 93 \% \text { of } \\
\text { supply costs }\end{array}$ & \\
\hline [73] & $\begin{array}{l}\text { Reduction of } \mathrm{CO}_{2} \text { emissions, reduction of the } \\
\text { amount of waste that is currently sent to } \\
\text { landfill, long-term storage of the } \mathrm{CO}_{2} \text {, water } \\
\text { savings, and reduction of dependence on } \\
\text { petroleum-based materials }\end{array}$ & $\begin{array}{l}\text { Increase of the production, cost reduction, and } \\
\text { creation of new sources of income }\end{array}$ & \\
\hline [36] & $\begin{array}{l}\text { Industrial symbiosis complexes with two and } \\
\text { six factories would allow to avoid equivalent } \\
\mathrm{CO}_{2} \text { emissions of approximately } 78 \\
\mathrm{kteCO}_{2} / \text { year and } 377 \mathrm{kteCO}_{2} / \text { year, respectively }\end{array}$ & $\begin{array}{l}\text { Implementation of a steam exchange system } \\
\text { between the two chemical plants and the thermal } \\
\text { plant, with a distance of } 1.8 \mathrm{~km} \text {, could reduce the } \\
\text { annual heat costs of the plants by approximately } \\
15 \% \text {, with a payback period ofeight } 8 \text { years for } \\
\text { recovery of infrastructure investment costs }\end{array}$ & \\
\hline [34] & $\begin{array}{l}\text { Twenty projects would prevent } 7207 \text { tons of } \\
\text { waste disposal and } 1126 \text { tons of greenhouse } \\
\text { gas emissions and would reduce energy } \\
\text { consumption by } 619,500 \mathrm{kWh} \text { and water } \\
\text { consumption by } 146,000 \mathrm{~m}^{3} \text { per year }\end{array}$ & $\begin{array}{l}\text { It is estimated that the } 20 \text { projects can generate } \\
\text { economic benefits in the amount of approximately } \\
\$ 760,000 \text { USD, considering both cost savings and } \\
\text { additional revenue; on average, each project was } \\
\text { estimated to generate about } \$ 38,000 \text { USD, with a } \\
\text { three-month payback period }\end{array}$ & \\
\hline
\end{tabular}


Table 3. Cont

\begin{tabular}{|c|c|c|c|}
\hline $\begin{array}{l}\text { Potential Industrial } \\
\text { Symbiosis (Refs.) }\end{array}$ & Environmental Benefits & Economic Benefits & Social Benefits \\
\hline [95] & $\begin{array}{l}\text { Energy reduction up to } 35 \% \text {, reduction in } \\
\text { water consumption up to } 50 \% \text {, and reduction } \\
\text { in greenhouse gas (GHG) emissions by } 20 \%\end{array}$ & Cost of waste disposal is practically eliminated & \\
\hline [39] & $\begin{array}{l}\text { Save raw material } 2.5 \mathrm{t} \text { and energy } 12.25 \mathrm{GJ} / \mathrm{t} \\
\text { steel; } 1 \mathrm{t} \text { waste plastic could substitute } 1.2 \mathrm{t} \\
\text { coke; save material of clinker } 500 \mathrm{kt} / \mathrm{year} ; \\
\text { reduce slag by } 500 \mathrm{kt} / \mathrm{y} \text {; in total, resource } \\
\text { saving and waste reduction reduce the } \mathrm{CO}_{2} \\
\text { emissions by } 1028.06 \mathrm{kt}-\mathrm{CO}_{2} / \mathrm{y}\end{array}$ & $\begin{array}{c}\text { In terms of raw material saving, fossil fuel } \\
\text { saving, and solid waste reduction, cost } \\
\text { reduction is 54.14MUSD/y, } 13.84 \mathrm{MUSD} / \mathrm{y} \text { and } \\
4.23 \mathrm{MUSD} / \mathrm{y}\end{array}$ & \\
\hline [106] & $\begin{array}{l}\text { In the scenario for the total of industrial and } \\
\text { urban symbioses, the } \mathrm{CO}_{2} \text { emission could be } \\
\text { reduced to } 1,108,682 \text { ton } \mathrm{CO}_{2} / \mathrm{yr} \text { (this } \\
\text { reduction of } \mathrm{CO}_{2} \text { emission is approximately } \\
2 \% \text { of the total } \mathrm{CO}_{2} \text { emissions in Ulsan) }\end{array}$ & $\begin{array}{l}\text { The fuel cost could be reduced to } \$ 352.5 \\
\text { million USD/yr }\end{array}$ & \\
\hline [120] & $\begin{array}{c}\text { Rationalization of land use, avoidance of } \\
\text { greenhouse gas emissions and toxic gases, and } \\
\text { minimization of the needed inputs and } \\
\text { equipment }\end{array}$ & $\begin{array}{c}\text { Liquid present value: } \$ 10.93 \text { million USD, } \\
\text { economical revenue: } 16.29 \% / \text { year, and return } \\
\text { time: } 4.6 \text { years }\end{array}$ & $\begin{array}{l}\text { Creation of } 241 \text { jobs in the initial } \\
\text { phase and more than } 5400 \text { in the } \\
\text { eight months of harvest, } \\
\text { construction of civil and social } \\
\text { facilities }\end{array}$ \\
\hline [124] & $\begin{array}{l}\text { Chemical release due to dust containment } \\
\text { avoided, avoidance of release of toxic } \\
\text { chemicals to environment and ground water } \\
\text { contamination, avoids } \mathrm{CaCl}_{2} \text { release to marine } \\
\text { environment, less use of virgin resources and } \\
\text { less environmental burdens by avoiding } \\
\text { nitrogen oxide emissions }\end{array}$ & $\begin{array}{l}\text { Avoid fines from dust emissions, from waste } \\
\text { water and from emissions; savings to company } \\
\text { and savings in the costs of using less water } \\
\text { from other sources; revenue from } \mathrm{CaCl}_{2} \text {, from } \\
\text { the sale of ammonium nitrate, and from } \mathrm{SiO}_{2} \\
\text { sales }\end{array}$ & $\begin{array}{l}\text { Respiratory effects from fine dust } \\
\text { avoided; less health risks due to } \\
\text { reduced emissions, avoidance of } \\
\text { long-term exposure to } \mathrm{SiO}_{2} \text {, and } \\
\text { avoidance of release of nitrogen } \\
\text { oxides }\end{array}$ \\
\hline
\end{tabular}




\subsection{Cases of Potential Industrial Symbiosis Applied to New Products and New Uses of Waste}

Research into new uses for waste and the manufacture of new products based on industrial symbiosis is essential in order to reduce the consumption of raw materials and reduce waste sent to landfills and incineration plants. However, despite the environmental and economic benefits of this reduction, the process of moving from research to practice is not always rapid or, indeed, possible. In addition to the barriers to the creation and development of industrial symbiosis, which are often referred to in the literature, such as a lack of trust among potential collaborators [33,116], the risks and uncertainties associated with the costs and benefits of such synergies $[18,131]$, and a lack of knowledge [34,41], there are other more specific obstacles that impede these new uses. Current legislation restricting the integration of new waste materials into productive processes [132,133] and the toxicity of some of these waste materials [134] are examples of barriers that can hinder the flow of waste materials and thus condition the development of future synergies. Thus, several studies have investigated future relationships of industrial symbiosis with a focus on the use of new waste materials and their reutilisation in the manufacture of existing or new products. Table 4 presents a summary of these studies, and in addition to the location and main characteristics of the industrial symbiosis, describes the methods used in the various studies. The different case studies are grouped into regions, i.e., Europe, Oceania, North America, and South America, which are sorted into descending order in terms of the frequency with which they appear in the studies. In cases with an equal number of articles, the ordering was carried out based on the date of publication, in ascending order.

It can be seen that, although these cases are few in number, a great variety of industries is involved in potential industrial symbiosis, and there is a wide range of different waste materials and potential uses of these in the manufacture of new or existing products. The geographical distribution is also relatively varied, with studies carried out in Europe, North America, South America, and Oceania. Although not all of these studies were contextualised with regard to a specific location, the vast majority studied the potential for using new waste materials within a given geographical context. 
Table 4. Potential applications of industrial symbiosis to various products and wastes, and studies analysing these applications.

\begin{tabular}{|c|c|c|c|c|c|c|c|}
\hline Country & Location/Region & Activity/Process & Waste/By-Products & Final Product/Use & Method & $\begin{array}{l}\text { Publication } \\
\text { Year }\end{array}$ & Refs. \\
\hline Finland & & $\begin{array}{l}\text { Bioenergy production } \\
\text { and forest products } \\
\text { industry waste water } \\
\text { treatment }\end{array}$ & $\begin{array}{l}\text { Bio fly ash and bio } \\
\text { sludge }\end{array}$ & Forest fertilizer & $\begin{array}{l}\text { Laboratory scale production and } \\
\text { test, life cycle assessment }\end{array}$ & 2016 & [135] \\
\hline Finland & $\begin{array}{l}\text { Oulu, Raahe and } \\
\text { Kemi }\end{array}$ & $\begin{array}{l}\text { Pulp and paper mill, } \\
\text { carbon steel plant, } \\
\text { mine, and power plant }\end{array}$ & $\begin{array}{l}\text { Lime waste residues, } \\
\text { green liquor dregs, } \\
\text { steel ladle slags, } \\
\text { desulphurization slag, } \\
\text { attle rock, bottom ash, } \\
\text { fly ash, and paper mill } \\
\text { sludge }\end{array}$ & $\begin{array}{l}\text { Soil amendment } \\
\text { pellets, low-grade } \\
\text { concrete, and mine } \\
\text { filler }\end{array}$ & $\begin{array}{l}\text { Life cycle assessment, CML } \\
\text { impact assessment method, } \\
\text { global warming potential } \\
\text { assessment and exergy analysis } \\
\text { method, dimensional analysis } \\
\text { approach, primary exergy } \\
\text { conversion efficiency of the } \\
\text { production process }\end{array}$ & 2016 & [133] \\
\hline Greece & & $\begin{array}{l}\text { Biodiesel plants, } \\
\text { agro-industries, } \\
\text { lignite-based power } \\
\text { generation plant, and } \\
\text { agricultural } \\
\text { biomass-based } \\
\text { combined heat and } \\
\text { power plant }\end{array}$ & $\begin{array}{l}\text { Crude glycerol and } \\
\text { agricultural biomass }\end{array}$ & $\begin{array}{l}\text { Alternative fuels } \\
\text { production }\end{array}$ & Experiments in a laboratory scale & 2016 & [136] \\
\hline $\begin{array}{l}\text { United } \\
\text { Kingdom }\end{array}$ & $\begin{array}{l}\text { North east of } \\
\text { England }\end{array}$ & Integrated steel mill & $\begin{array}{l}\text { Vanadium-bearing } \\
\text { steel slags }\end{array}$ & & $\begin{array}{l}\text { Semi-structured interviews with } \\
\text { industry representatives, industry } \\
\text { associations, and consultants }\end{array}$ & 2017 & [132] \\
\hline Wales & Baglan & $\begin{array}{l}\text { Foundry and research } \\
\text { centre }\end{array}$ & $\begin{array}{l}\text { Platinum from waste } \\
\text { thermocouples }\end{array}$ & $\begin{array}{c}\text { Catalytic } \\
\text { electrodes suitable } \\
\text { for dye-sensitized } \\
\text { solar cell } \\
\text { production }\end{array}$ & $\begin{array}{c}\text { Synthesis and analysis of } \\
\text { chloroplatinic acid samples, } \\
\text { fabrication and characterization } \\
\text { of platinized counter-electrodes, } \\
\text { electrical impedance spectroscopy } \\
\text { analysis, chemical analysis, } \\
\text { supply and environmental impact } \\
\text { analysis, cost-benefit analysis }\end{array}$ & 2018 & [137] \\
\hline
\end{tabular}


Table 4. Cont.

\begin{tabular}{|c|c|c|c|c|c|c|c|}
\hline Country & Location/Region & Activity/Process & Waste/By-Products & Final Product/Use & Method & $\begin{array}{l}\text { Publication } \\
\text { Year }\end{array}$ & Refs. \\
\hline Italy & $\begin{array}{l}\text { S. Angeli di } \\
\text { Rosora, Marche }\end{array}$ & $\begin{array}{l}\text { Building and } \\
\text { automotive sector }\end{array}$ & $\begin{array}{l}\text { Retired lithium-ion } \\
\text { electric vehicle } \\
\text { batteries }\end{array}$ & $\begin{array}{l}\text { Battery energy } \\
\text { storage systems }\end{array}$ & $\begin{array}{l}\text { Experimental tests, simulation of } \\
\text { the energy system, integrated } \\
\text { load match analysis and life cycle } \\
\text { assessment approach, grid } \\
\text { interaction indicators }\end{array}$ & 2019 & [138] \\
\hline Australia & Western Australia & $\begin{array}{l}\text { Nitric acid plants and } \\
\text { fertilizer producer }\end{array}$ & $\begin{array}{l}\text { By-products formed } \\
\text { from chemical } \\
\text { absorption of nitrogen } \\
\text { oxide }\end{array}$ & $\begin{array}{l}\text { Potassium nitrate } \\
\text { fertilizer }\end{array}$ & $\begin{array}{l}\text { Life cycle assessment and life } \\
\text { cycle inventory; process } \\
\text { engineering applications: } \\
\text { stoichiometric balances, } \\
\text { thermodynamic properties of } \\
\text { chemical reactions. and solubility } \\
\text { conditions; Australian } \\
\text { Environmental Impact method; } \\
\text { uncertainty analysis }\end{array}$ & 2016 & [139] \\
\hline Australia & Kwinana & $\begin{array}{l}\text { Phosphoric acid } \\
\text { manufacture }\end{array}$ & Phosphogypsum & $\begin{array}{l}\text { Paper and } \\
\text { fertilizer }\end{array}$ & $\begin{array}{l}\text { Life cycle assessment and life } \\
\text { cycle inventory; economic and } \\
\text { social analysis; Economic } \\
\text { Analyzer software; sensitivity } \\
\text { analysis; indicators for social } \\
\text { implications assessment: } \\
\text { employment opportunity, } \\
\text { intergenerational social equity, } \\
\text { and avoided land use }\end{array}$ & 2018 & [140] \\
\hline USA & Southwest region & $\begin{array}{l}\text { Original equipment } \\
\text { manufacturer } \\
\text { dealership, battery } \\
\text { diagnostic centre, and } \\
\text { photovoltaic industry }\end{array}$ & $\begin{array}{c}\text { End of life electric } \\
\text { vehicles lithium-ion } \\
\text { batteries }\end{array}$ & $\begin{array}{l}\text { Storage of } \\
\text { renewable energy } \\
\text { generated through } \\
\text { photovoltaic } \\
\text { technology }\end{array}$ & $\begin{array}{l}\text { Avoided environmental impacts } \\
\text { for reusing degraded electric } \\
\text { vehicles batteries and tool for } \\
\text { reduction and assessment of } \\
\text { chemicals and other } \\
\text { environmental impact }\end{array}$ & 2019 & [141] \\
\hline
\end{tabular}


Table 4. Cont.

\begin{tabular}{|c|c|c|c|c|c|c|c|}
\hline Country & Location/Region & Activity/Process & Waste/By-Products & Final Product/Use & Method & $\begin{array}{l}\text { Publication } \\
\text { Year }\end{array}$ & Refs. \\
\hline USA & & $\begin{array}{l}\text { Automobile industry } \\
\text { and building and } \\
\text { construction industry }\end{array}$ & Waste steel scrap & $\begin{array}{l}\text { Metal facade } \\
\text { systems for } \\
\text { buildings' } \\
\text { exteriors }\end{array}$ & $\begin{array}{l}\text { Required capital cost and } \\
\text { required energy consumption for } \\
\text { making a new metal building } \\
\text { facade product by recycling and } \\
\text { by directly reusing waste steel } \\
\text { scrap; potential capital cost } \\
\text { savings and energy consumption } \\
\text { savings by reusing waste steel } \\
\text { scrap when compared with } \\
\text { recycling }\end{array}$ & 2019 & [142] \\
\hline \multirow[t]{3}{*}{ Brazil } & $\begin{array}{l}\text { Quadrilátero } \\
\text { Ferrífero, Minas } \\
\text { Gerais }\end{array}$ & $\begin{array}{l}\text { Iron mining and steel, } \\
\text { and brick } \\
\text { manufacturing } \\
\text { industry }\end{array}$ & $\begin{array}{l}\text { Steel slag and iron ore } \\
\text { tailings }\end{array}$ & Solid brick & $\begin{array}{l}\text { Evaluation of chemical } \\
\text { composition of the samples by } \\
\text { energy dispersive X-ray } \\
\text { spectroscopy, expansibility test } \\
\text { using the method defined in } \\
\text { Brazilian Standard ABNT NBR } \\
\text { NM 13, experimental procedures, } \\
\text { visual analysis, mechanical tests, } \\
\text { comparative evaluation, QE-CO } \\
\text { method }\end{array}$ & 2018 & [143] \\
\hline & & & $\begin{array}{l}\text { Wastes from laptop } \\
\text { and photovoltaic } \\
\text { system }\end{array}$ & & $\begin{array}{c}\text { Design measures and } \\
\text { technological, environmental, } \\
\text { and economic implications } \\
\text { analysis }\end{array}$ & 2012 & [144] \\
\hline & & $\begin{array}{l}\text { Cement industry and } \\
\text { municipal solid waste } \\
\text { management }\end{array}$ & $\begin{array}{l}\text { Energy-from-waste air } \\
\text { pollution control } \\
\text { residues (fly ash and } \\
\text { calcium or sodium } \\
\text { salts from scrubbing } \\
\text { of acid gases) }\end{array}$ & Blended cements & $\begin{array}{l}\text { Analysis of pH-dependent } \\
\text { leachability of pollutants from } \\
\text { granular material and } \\
\text { diffusion-controlled leaching } \\
\text { from monolithic specimens; } \\
\text { laboratory investigation of eight } \\
\text { EfW APC residues }\end{array}$ & 2014 & [134] \\
\hline
\end{tabular}


Table 4. Cont.

\begin{tabular}{|c|c|c|c|c|c|c|c|}
\hline Country & Location/Region & Activity/Process & Waste/By-Products & Final Product/Use & Method & $\begin{array}{c}\text { Publication } \\
\text { Year }\end{array}$ & Refs. \\
\hline & & $\begin{array}{l}\text { Winery and } \\
\text { environmental } \\
\text { industries }\end{array}$ & Grape marc & $\begin{array}{l}\text { Bioadsorbent for } \\
\text { the desalination of } \\
\text { water containing } \\
\text { copper (II) sulfate }\end{array}$ & $\begin{array}{l}\text { Elemental analysis, preliminary } \\
\text { adsorption experiments, } \\
\text { experimental design for } \\
\text { establishing the optima } \\
\text { conditions to remove copper(ii), } \\
\text { quantification of copper(ii) } \\
\text { through a spectrophotometric } \\
\text { analysis, quantification of } \\
\text { adsorbent capacity and } \\
\text { percentage of copper removal, } \\
\text { X-ray diffraction analysis, } \\
\text { statistical analysis-response } \\
\text { surface method, and multiple } \\
\text { regressions using the least } \\
\text { squares method }\end{array}$ & 2018 & [145] \\
\hline
\end{tabular}


In some cases, geographical location was not constraining, and the use of certain waste materials could be transferred to several locations. For example, waste materials from common industries and those available in most countries can be used to extend the range of application of industrial symbiosis. One example of this is a case study of the production of potential symbiosis products such as soil amelioration pellets, low-competence concrete, and mine filler from a mixture of waste materials from multiple industries, such as pulp and paper mills, carbon steel plants, mines, and power plants [133]. Although this was studied in the context of Finland, this symbiosis could be replicated in numerous different locations due to the nature of the industries available. Another example was a study of the use of wine grape pulp to produce a bio-adsorbent for the removal of copper sulphate from water [145]; this symbiosis between the winery and environmental industries could also be reproduced in several distinct locations.

In other cases, however, geographical location can condition or incentivise the use of certain waste materials in the symbiotic process. For example, the strong presence of a particular type of industry can be an enhancer for industrial symbiosis and the search for new solutions to the waste generated by the production process. One example is the pulp and paper industry, which has a long tradition in Finland and is responsible for large volumes of production [21] and consequently high levels of waste generation. One of the studies focused on the potential uses of sludge resulting from the processes of wastewater treatment in the forestry industry and of fly ash resulting from the production of bioenergy for the production of a forest fertiliser [135]. In Brazil, the steel, mining, and construction sectors have a strong presence and are responsible for large-scale generation of waste and greenhouse gas emissions, and this has boosted the search for sustainable solutions. Thus, new solutions for the use of iron and steel mining waste were studied as an example of potential symbiosis in the production of solid brick/construction blocks in the Quadrilátero Ferrífero zone [143].

Current progress and the consequent emergence of new products have created new streams of waste, and with them the need to provide solutions which promote a more sustainable end of life. If these wastes result from or are integrated into a sector or product that has a significant environmental impact over its life cycle or a certain part of it, industrial symbiosis makes it possible to reduce the environmental impact of this sector or product. One of the examples found in the literature was the potential use of end-of-life electric vehicle lithium-ion batteries as storage systems for the renewable energy produced from photovoltaic systems in the generation of electricity for buildings [138,141]. In addition to using a waste material that is expected to increase over the next few years, this potential synergy also contributes to the reduction of carbon dioxide emissions from two sectors that are responsible for high greenhouse gas emissions_-buildings and the automotive sector. 
The study of new solutions based on industrial symbiosis is not only due to the inherent characteristics of certain waste materials, such as their toxicity and associated value, but also to the fact that the recycling process is often expensive and a large consumer of energy, meaning that it is not a viable solution. In the case of retrieval of valuable metals such as platinum, the recovered value sometimes does not cover the costs inherent in retrieval [137] if these are present in low concentrations, and industrial symbiosis can address this limitation. One example is a case study of Baglan, South Wales, in which, due to the local proximity between the stakeholders of potential synergy, the recovery of platinum for the production of catalytic electrodes for dye-sensitised solar cells could be translated into environmental, economic, and social benefits [137]. The potential direct use of sheet metal scrap from the automobile industry in the manufacture of new facade systems for the exterior of buildings could also lead to a reduction in costs of approximately $40 \%$ and a reduction in energy consumption of approximately $67 \%$ compared to a conventional recycling process [142].

All these studies were supported by several methods with different objectives. Since the main aim of these publications was to promote the use of new waste materials or the production of new products empowered by industrial symbiosis, it is not surprising that the predominant methods were those associated with laboratory-scale experiments. These tests were carried out to study not only the characteristics of waste materials $[137,138]$ but also the final products $[135,143]$ in order to guarantee their functionality and suitability for these purposes. A knowledge of the potential environmental, economic and social benefits that these new uses of waste can provide is also very relevant, as these can drive realisation. In the same way as for studies of potential industrial symbiosis between companies, the environmental component was the most frequently analysed aspect [135,138-140], followed by economic factors [137,140,142,144], and finally social components [140]. The potential benefits from the use of new waste materials and the manufacture of new products based on industrial symbiosis are extremely diverse. Table 5 lists the main environmental, economic, and social benefits that could be achieved if some of these potential symbioses were put into practice. 
Table 5. Main environmental, economic, and social benefits of the potential use of waste and products through industrial symbiosis.

\begin{tabular}{|c|c|c|c|}
\hline $\begin{array}{c}\text { Potential Industrial } \\
\text { Symbiosis (Refs.) }\end{array}$ & Environmental Benefits & Economic Benefits & Social Benefits \\
\hline [135] & $\begin{array}{l}\text { Reduction of global warming potential (GWP) by } \\
99 \% \text { : production of } 1000 \mathrm{~kg} \text { of potential symbiosis } \\
\text { granules would produce GWP burdens of } 11.75 \mathrm{~kg} \\
\mathrm{CO}_{2} \text {-equiv. and the existing NPK-fertilizers } \\
\text { produced a GWP burden of } 1304.92 \mathrm{~kg} \mathrm{CO}_{2} \text {-equiv. }\end{array}$ & & \\
\hline [139] & $\begin{array}{l}\text { Reduce the overall GWP, acidification potential and } \\
\text { eutrophication potential per kg } \mathrm{KNO}_{3} \text { produced by } \\
7.8 \mathrm{~kg} \text { of } \mathrm{CO}_{2}-\mathrm{e}, 0.122 \mathrm{~kg} \mathrm{SO} \mathrm{SO}_{2}-\mathrm{e} \text { and } 0.075 \mathrm{~kg} \mathrm{PO}_{4}-\mathrm{e} \\
\text { respectively in comparison to the production of } \\
\text { conventional } \mathrm{KNO}_{3} \text { fertilizer and could reduce } \\
\text { GHG emissions by } 45 \%\end{array}$ & & \\
\hline [142] & & $\begin{array}{l}\text { Reusing the sheet metal scrap over } \\
\text { conventional recycling of the same } \\
\text { material would lead to a cost reduction } \\
\text { of approximately } 40 \% \text { ( } \$ 400 \text { USD/ton) } \\
\text { and savings of approximately } 67 \% \\
(10,000 \mathrm{MJ} / \text { ton) of energy consumption }\end{array}$ & \\
\hline [136] & $\begin{array}{c}\text { Provide a rather short-term solution to the existing } \\
\text { environmental problem of waste glycerol, } \\
\text { contributes to increase sustainability and reduce } \\
\text { environmental footprint }\end{array}$ & $\begin{array}{l}\text { Decrease in the cost of biodiesel } \\
\text { production }\end{array}$ & \\
\hline [132] & $\begin{array}{l}\text { Removal of elements of environmental risk, such as } \\
\text { vanadium }\end{array}$ & Income from the sale of recovered metals & \\
\hline [137] & $\begin{array}{l}\text { Per year, divert } \sim 50 \mathrm{~g} \text { of platinum from landfill, } \\
\text { avoid up to } 1400 \mathrm{~kg} \text { of } \mathrm{CO}_{2} \text { emissions associated } \\
\text { with primary production of an equivalent quantity } \\
\text { of platinum, and give enough platinum to produce } \\
\text { catalytic electrodes for } \sim 500 \mathrm{~m}^{2} \text { of dye-sensitized } \\
\text { solar cells, which could supply clean energy for } 12 \\
\text { homes in the locality (South Wales) }\end{array}$ & $\begin{array}{l}\text { Provide } 63 \% \text { materials cost savings for } \\
\text { electrode preparation in comparison to } \\
\text { purchasing commercially available } \\
\text { chloroplatinic acid hydrate }\end{array}$ & Provide $\sim 5$ days employment \\
\hline
\end{tabular}


Table 5. Cont.

\begin{tabular}{|c|c|c|c|}
\hline $\begin{array}{c}\text { Potential Industrial } \\
\text { Symbiosis (Refs.) }\end{array}$ & Environmental Benefits & Economic Benefits & Social Benefits \\
\hline [140] & $\begin{array}{l}\text { Reduce solid waste associated with traditional } \\
\text { paper production, where the average amount of } \\
\text { solid waste reduction from studied options is } 0.01 \\
\mathrm{~kg} / \mathrm{kg} \text { of paper, reduction of contamination of } \\
\text { underground water sources or land from leaching of } \\
\text { the phosphogypsum (PG) constituents }\end{array}$ & $\begin{array}{l}\text { PG recycling is expected to reduce } \\
\text { approximately } 12,000 \mathrm{~m}^{2} \text { of land used for } \\
\text { stockpiling of PG (based on the average } \\
\text { annual operation of the plant of } 25,000 \\
\text { tons of PG), which could be reutilized for } \\
\text { other economic benefits such as } \\
\text { expansion of the industrial plant or be } \\
\text { sold for revenue generation }\end{array}$ & $\begin{array}{l}\text { Employment opportunities for } \\
\text { people in the surrounding areas; } \\
\text { it is expected that } 18 \text { job } \\
\text { opportunities will be needed }\end{array}$ \\
\hline [143] & $\begin{array}{l}\text { Reduction in GHG emissions. } \\
\text { The construction of the } 126,000 \text { households using } \\
\text { the T2 brick would generate a reduction of } 465,588.9 \\
\text { tons of } \mathrm{CO}_{2} \text {, when compared to the concrete block }\end{array}$ & $\begin{array}{l}\text { The carbon credits related to } \mathrm{CO}_{2} \\
\text { reduction in the simulated venture could } \\
\text { be traded for } \$ 4.3 \text { million USD }\end{array}$ & Access to lower-cost housing \\
\hline
\end{tabular}




\section{Drivers and Barriers to the Realisation of Potential Industrial Symbiosis and Strategies to Overcome These Barriers}

A knowledge of the drivers and barriers to the implementation of industrial symbiosis is essential in order to develop measures that enhance the application of this practice. Based on the studies of potential industrial symbiosis analysed above, this section compiles the various drivers, i.e., factors that promote and facilitate the development of industrial symbiosis, and barriers, i.e., the factors that hinder the implementation of this practice. Selected strategies for overcoming the various barriers are also highlighted, as these can create conditions for the various cases of potential industrial symbiosis to materialise.

\subsection{Drivers and Enablers of the Realisation of Potential Industrial Symbiosis}

An analysis of the articles on potential industrial symbiosis leads to the conclusion that there are a number of factors that play important roles in the realisation of industrial symbiosis relationships. Knowing the environmental, economic and social benefits that this practice provides is important in promoting the creation of synergy networks [146]; however, these are not always the main drivers of this practice, and many other drivers have been identified in studies of potential industrial symbiosis as being conducive for companies to participate in symbiosis networks. In most cases, it is not one factor but a set of factors that create favourable conditions for the development of symbiosis.

The economic, environmental, political, and social context of a country can be decisive in the way sustainability issues are addressed and consequently in how they can favour or condition the development of industrial symbiosis. The distribution of a number of potential industrial symbiosis articles by country, as illustrated in Figure 3, reflects the characteristic context of each country.

Existing legislation, plans and policies in each country are also repeatedly referred to as drivers of industrial symbiosis $[82,101,115,118,120]$. Companies are encouraged to set up synergy networks through imposing limits on emission or waste disposal through regulations and taxation, facilitating the use of waste, and allocating funds.

The higher numbers of studies of potential industrial symbiosis in Europe cannot be dissociated from the efforts that have been undertaken by European countries to reduce greenhouse gas emissions and to promote the more efficient use of resources. These efforts have been driven by the European Commission, which has established a number of directives, communications and programs with the provision of funds. One example is the "Roadmap to a Resource Efficient Europe" communication, which proposed a framework for action to ensure the sustainable management of all resources without sacrificing economic growth [147]. Another example is the communication "Closing the loop-An EU action plan for the Circular Economy". This communication underlined the importance of industrial symbiosis and proposed to facilitate this practice through cooperation with the Member States, guaranteed funding through cohesion policy funds, and the research and innovation framework program Horizon 2020 [148]. Another initiative launched by the European Commission was Directive 2018/851 on waste; in addition to highlighting the great advantages of improving the efficiency of waste management and recognising waste as a resource, this acknowledges the importance of industrial symbiosis and encourages Member States to take steps to facilitate it [149].

The European countries for which the highest numbers of cases of potential industrial symbiosis have been published are Italy, Sweden, and Finland. All of these countries have common factors that may have contributed to fostering the study of new industrial symbiosis relationships and their implementation, such as (i) a greater concern with environmental issues and the search for sustainable solutions, (ii) the established existence of cases of industrial symbiosis over several years, (iii) a considerable number of cases of self-organised symbiosis networks, (iv) the existence of facilitators through national agencies or local governments, and (v) more stringent environmental regulations $[18,21,41,150,151]$.

The realisation of two cases of industrial symbiosis, involving the automotive [64] and agri-food [65] industries in the Italian Region of Abruzzo, is another example of the combination of several factors in 
realising the potential of symbiosis. In this case, good communication routes, favourable geographical positions, stakeholder involvement, and the facilitating role of the president of Consorzio Italiano Subfornitura Impresa (CISI) in the case of the automotive industry were viewed as driving factors in the development of industrial symbiosis [152].

China has the highest number of published cases of industrial symbiosis [19] and potential such cases. This may be associated with a set of measures that China has implemented over recent years, such as the implementation of policies and plans, financial incentives, and research incentives. These measures have attempted to contain the negative effects of increasing industrialisation and urbanisation in recent years $[153,154]$, such as increased carbon dioxide emissions $[153,155,156]$, increased amounts of industrial solid waste [154,157], and increasing resource consumption [39,97]. The National Pilot Circular Economy Zone Programme, launched by the State Environmental Protection Administration in 2001, and the laws that have been applied since 2003 to promote the circular economy, are examples of these measures. While not primarily aimed at promoting industrial symbiosis, they contribute to the spread of this practice by providing increased awareness of the importance of resource reuse and recognition of the fundamental role of the circular economy in China's development [23,24]. The China National Eco-Industrial Demonstration Programme launched in 2000 by the State Environmental Protection Administration [25] has also contributed to the increase in the number of potential industrial symbiosis cases and China's leadership in the publication of case studies [19]. This programme has enabled the development of the largest national network of eco-industrial parks, in which industrial symbiosis practices have been promoted [158,159].

The predominance of certain types of industry within countries can also be a driving factor for the creation of industrial symbiosis networks. This is particularly true if they are large consumers of resources and emitters of greenhouse gases, such as the steel and iron industry in China [97,160], and if they play a key role in economic development, such as the agri-food industry in Italy [65] and the iron, steel, and cement industries in China $[160,161]$. Moreover, these industries have a longstanding tradition in these countries and are located in industrially mature areas, which Jensen et al. [92] have shown to facilitate industrial symbiosis.

A diversity of industries has also frequently been highlighted as conducive to the establishment of industrial symbiosis relationships [76,114], since this opens up a range of opportunities due to the variety of wastes and the numbers of companies that produce them and have the potential to incorporate them into their processes. If there are several companies carrying out the same type of economic activity, this can be an added advantage, since it ensures a more constant flow of waste [77], while if there are no other companies nearby to ensure the incorporation of these wastes into their processes, the viability of industrial symbiosis is compromised. The fact that there are several industries carrying out the same type of economic activity may also enhance other synergies, such as infrastructure sharing and the joint provision of services.

If a company can function as an anchor tenant, this can be an important factor in driving the realisation of industrial symbiosis relationships $[76,82,91,93,114]$. These companies are able to attract and anchor a network of companies, not only in terms of the supply of materials but also the reuse of waste. There are some examples of such cases reported in the literature, such as a power plant in Honolulu in the US [162], mining firms in Gujiao, China [163], and a pulp and paper mill in Kouvola, Finland [164].

Although not an indispensable requirement for establishing the synergy network, geographical proximity between the potential participants in industrial symbiosis is often referred to as a facilitator [11, $36,82,91]$. Establishing symbiosis networks with nearby companies can increase trust in the relationship. In addition, the fact that waste is mostly of low economic value, transportation and environmental costs may no longer compensate for the symbiosis connection over long distances.

The existence of industrial symbiosis networks that have already been established in a given place can be a driving force for creating new synergy linkages and extending the network to new companies, since the internal structures [114] and trust relationships that facilitate this development [40] are 
already established. In addition, there is evidence that these networks can be of benefit to the parties involved, not only in terms of the reduction of waste treatment and landfill costs, but also in terms of the savings made in the acquisition of raw materials, and profits from the sales of waste. If there are entities that can support and facilitate existing on-site cases of industrial symbiosis, these can also act as enablers for the creation of new connections. This role can be played either by public entities such as local governments or by private entities such as business associations [18,41]. These entities, which are aware of the reality of the site, can more easily identify new partners for infrastructure sharing and joint provision of services, as well as new companies that may be able to use waste that is not yet in use, or that can provide waste to companies already involved in industrial symbiosis. However, in places where no synergy networks have been established, the role of these facilitators can be highly relevant, as mentioned in some of the cases analysed here $[60,76,82,107]$. They can provide training for companies, facilitate the exchange of information [53], foster cooperation and trust between companies [76], and coordinate and help identify possible symbiosis relationships [107].

\subsection{Barriers to the Realisation of Potential Industrial Symbiosis}

Despite the recognised environmental, economic and social benefits that industrial symbiosis can provide, there are a number of barriers that hinder its development. The literature review shows that these barriers can be of various types, such as economic, technical, regulatory/legal, organisational, social, and cultural $[18,33,47,131,165]$. By analysing selected publications on potential industrial symbiosis, it was possible to identify several of these barriers.

Several studies of potential industrial symbiosis have pointed out the lack of appropriate policies as a barrier to the application of this practice [53,65,116,122]. Low taxes on landfill disposal [122], a lack of policies that encourage and regulate industrial symbiosis [116], a lack of funds to promote this practice [116], and deficient regulatory frameworks [122] are some of these barriers. In addition, existing legislation may limit the implementation of synergy relationships, especially if it is too rigid, unclear, or inconsistent. One example is Italy's regulatory system, which is referred to in studies of potential industrial symbiosis $[53,65]$ as constraining companies with regard to the use of waste.

There are also others barriers to the creation of industrial symbiosis networks. The first is associated with the reluctance of companies to establish synergistic relationships, not only due to a lack of knowledge of the industrial symbiosis mechanism [116,122] but also due to a lack of knowledge of other companies with the potential to receive or provide waste $[9,68]$. In addition, a lack of trust $[82,116]$, resistance to providing data on processes and generated waste [122], and uncertainty related to the profitability of the symbiosis network [75] and the associated costs and risks [82] were also identified as barriers to the development of symbiosis relationships.

The fact that companies are implementing measures to reduce waste generation has also been identified as a barrier to the development of industrial symbiosis [68], as there is a concern that the stream of waste involved cannot be guaranteed.

The economic component has been referred to by various authors $[18,166,167]$ as being essential in inducing companies to take the initiative to establish an industrial symbiosis relationship. If the economic value of raw materials is very close to that of waste, there is no incentive for companies to use waste in their production processes [37]. Moreover, the price that companies are willing to pay for waste may not be economically advantageous for the company producing such waste. In this case, there is no incentive for companies to divert waste from landfills and start a symbiosis relationship [68]. In addition to these factors, the role of stakeholders in deciding whether or not to initiate symbiosis relations should be highlighted, as there is often a lack of openness [34] and willingness [116] to initiate this kind of collaboration.

For the establishment of some symbiosis relationships, such as the sharing of waste heat, the initial costs associated with infrastructure are very high, and this makes companies reluctant to establish such symbioses $[75,106,107]$. A lack of availability of technologies required $[9,116]$ and the high costs 
of equipment [85] for the realisation of industrial symbiosis have also been identified as inhibiting the realisation of this practice.

The social and economic instability of a country can also condition the establishment of synergies, since although the issue of sustainability is recognised as being important; there may be social issues which take precedence [168]. In addition, the issue of survival is imperative in some countries with developing economies, and since the time between setting up projects and achieving results may often be long in these countries, this may constitute a barrier to the implementation of symbiosis [45].

\subsection{Strategies for Overcoming the Barriers to the Realisation of Potential Industrial Symbiosis}

Regulations and policies were most often referred to as being important for encouraging or limiting the establishment of industrial symbiosis relationships $[85,111,122,169]$. While the decision to establish a symbiosis relationship is made by a given entity, the role of policies is critical in encouraging this practice. Thus, in order for these to not function as barriers, it is necessary to provide legislation and policies that are clear, consistent, and less bureaucratic and can facilitate the process of waste use [170].

Economic incentives have also been highlighted as being important in the realisation of industrial symbiosis $[9,122]$. To create more efficient legislation to facilitate this practice, programmes can be coupled with the provision of funds to promote industrial symbiosis and offer monetary support for companies in terms of the construction of infrastructures or the acquisition of the equipment necessary for the realisation of these relationships [122].

However, even if there are a number of policies and programs that facilitate and encourage companies to establish symbiotic relationships, the companies themselves are often reluctant to make such connections. Thus, to drive the implementation of industrial symbiosis, it is necessary to disseminate information to companies. This can be realised through workshops, working group discussions, and other actions $[116,122]$ that provide the necessary information to companies on industrial symbiosis and its potential benefits. A knowledge of this practice can create the willingness to cooperate, which is fundamental for the realisation of symbiosis networks [68].

The role of facilitators such as local governments and industry associations has also been highlighted as a way to overcome various barriers [34,111], including a lack of confidence, a reluctance of companies to share their data and a fear of relying on other companies. These entities can provide training to various employees on the concept of industrial symbiosis, assist in the creation of trust and cooperation relationships, and help to identify new symbiosis relationships [34,165].

Some barriers such as a lack of knowledge of companies with potential to start symbiosis relationships and lack of trust can be overcome using digital platforms and programs [87]. These tools can enable social interaction between companies and facilitate a search for companies that can provide or receive waste. In addition, where appropriate, they can facilitate the choice of the best option based on prices, distances and potential environmental and economic benefits $[38,80,87]$.

In order to overcome the barriers associated with a lack of available technology, there is a need for increased investment by governments in research and development into technological innovations and greater involvement with research teams from university or business associations [9,37].

In the case of poorer countries with social problems such as high unemployment rates, low incomes, illiteracy, or low life expectancy, such as the cases studied in the Philippines, Liberia, India, and Bangladesh, the implementation of industrial symbiosis practices is more difficult. However, when properly supported, the implementation of this practice can make a positive contribution to the long-term sustainable development of these countries, as it makes it possible to combine environmental and economic issues with social aspects. These advantages translate into job creation, long-term links between companies and the possibility of small businesses entering the synergy network $[45,61,171]$. It is therefore essential to support these countries in the development of industrial symbiosis. Several authors have proposed measures for overcoming the characteristic barriers in these countries, such as (i) extending the symbiosis network to other stakeholders such as 
community leaders and government organisations [45], (ii) the establishment of policies that encourage symbiotic relationships between small businesses, such as small farms [45], (iii) the provision of subsidies [122], and (iv) helping to obtain international support created specifically for sustainable projects in developing countries [122].

The main drivers and barriers to achieving potential industrial symbiosis are very diverse, as illustrated in Figure 5, and overcoming the various barriers and achieving further dissemination of industrial symbiosis requires concerted action at various levels. It is therefore essential to coordinate the various entities and resources and to restructure existing regulatory systems. It is also necessary to support companies in paradigm shifting and raising awareness of the advantages of more sustainable practices, and in particular industrial symbiosis.

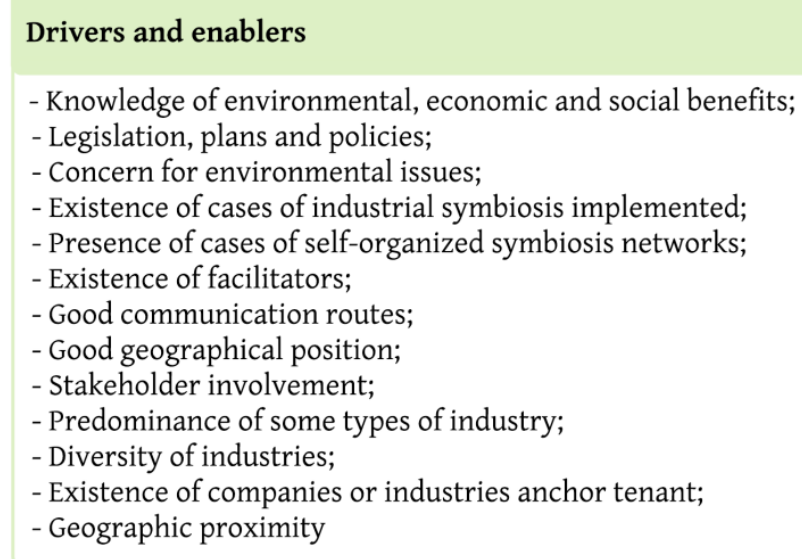

\section{Barriers}

- Lack of appropriate legislation and policies;

- Lack of knowledge of industrial symbiosis practice;

- Lack of knowledge of companies with potential to receive or provide waste;

- Lack of trust;

- Resistance to providing process and generated waste data;

- Uncertainty of the profitability of the symbiosis network;

- Associated costs and risks;

- Continuity of waste flow in sufficient quantity and quality;

- Fear of dependence;

- Low virgin material prices and economic value of waste;

- Limited willingness of stakeholders to collaborate;

- Initial cost associated with infrastructure and some equipment;

- Lack of technology availability;

- Social and economic instability of a country

Figure 5. Key drivers, enablers, and barriers to the realisation of potential industrial symbiosis, and strategies to overcoming these barriers.

\section{Conclusions}

Despite the large number of existing cases of industrial symbiosis, there is still huge scope for growth, as evidenced by the various studies that have been carried out to assess the potential application of this practice. A comprehensive review of the literature reveals that there is potential for the development of new industrial symbiosis relationships around the world, with a wide diversity in terms of network size, the types of economic activities involved and the types of waste stream. 
Most existing studies focus on countries where symbiosis is already widely applied, such as China, Sweden, Finland, and the US. However, the potential for industrial symbiosis has also been studied in countries where this practice has few or no existing cases, such as Egypt, the Philippines, and Colombia. Although most of these cases reproduce existing symbiosis relationships with regard to the activities and types of waste involved, there have been studies that have looked into the potential use of new waste and the manufacture of new products based on industrial symbiosis relationships. Furthermore, the potential for applying industrial symbiosis is not limited to replacing resources with waste; there are also many opportunities for other types of synergies, such as infrastructure sharing and joint provision of services.

Despite this great potential, it was only possible to verify the realisation of two of the cases of potential industrial symbiosis in the literature review. It can be inferred that there was either no interest from industry in the implementation of industrial symbiosis or, if the potential was realised, there was no follow-up that resulted in a publication. However, it is important to understand that there is interest from industry in implementing these cases. Some of the studies have a more theoretical character, and many of them resorted to interviews and site visits, which implies that industry is aware of the potential for industrial symbiosis. Thus, it is important to monitor the implementation of symbiosis in order to better understand the dynamics of implementation of this practice and the main factors enhancing its development. If potential cases of industrial symbiosis are not realised, it is relevant to analyse with companies the main barriers to this implementation.

The work carried out in this paper regarding knowledge of the potential for industrial symbiosis and the main barriers and drivers to its implementation may have theoretical implications. The characterisation of the various cases can contribute positively to the research efforts that have been developed to increase the application and diffusion of industrial symbiosis. Knowledge of the main drivers and barriers may also have implications for the development of theory, in terms of an understanding of industrial symbiosis and the main mechanisms that can drive or hinder it.

While an effort was made to ensure that the review of the bibliography was as comprehensive as possible, we limited our search to articles written in English and using only research articles, conference articles, book chapters and editorials, and this may have overlooked some cases of potential industrial symbiosis that could provide a greater understanding of this topic.

Of the various types of resource sharing available, most studies address the potential use of waste and the advantages that arise from its integration as a raw material in the production process. However, in future research, it is important to examine more case studies assessing the potential of infrastructure sharing, the joint provision of services, and the potential benefits to the companies, environment, and society. It will also be important to focus on the most favourable conditions and the factors determining implementation of symbiosis.

Future research could also assess whether various cases of potential industrial symbiosis have been implemented in order to increase our understanding of the mechanisms that drive or condition the creation of synergies and thereby promote the growth of industrial symbiosis initiatives.

Author Contributions: A.N. conducted the study, and wrote and prepared original draft. R.G. handled the conceptualisation, and the writing and editing of the manuscript. S.G.A. and J.C.O.M. supervised, revised and corrected the manuscript. C.P. helped with bibliography review.

Funding: Radu Godina would like to acknowledge financial support from Fundação para a Ciência e Tecnologia (UID/EMS/00667/2019). This work was also financially supported by the research unit on Governance, Competitiveness and Public Policy (UID/CPO/04058/2019), funded by national funds through FCT-Fundacão para a Ciência e a Tecnologia.

Conflicts of Interest: The authors declare no conflict of interest. 


\section{Appendix A}

Table A1. Potential industrial symbiosis applications and studies analysing these applications.

\begin{tabular}{|c|c|c|c|c|c|c|c|c|}
\hline Country & Location/Region & $\mathrm{NE}^{1}$ & Activity & Waste/By-Products & $\begin{array}{c}\text { Infrastructure } \\
\text { Sharing/Joint } \\
\text { Provision of Services }\end{array}$ & Method & $\begin{array}{l}\text { Publication } \\
\text { Year }\end{array}$ & Refs. \\
\hline \multicolumn{9}{|c|}{ Europe } \\
\hline Italy & $\begin{array}{l}\text { Murano, } \\
\text { Venetian } \\
\text { Lagoon }\end{array}$ & & Glass-based industry & Oxygen & Water treatment & $\begin{array}{l}\text { BATTER tool; direct } \\
\text { measurements at single } \\
\text { installations, mass flow } \\
\text { estimations, total amount of air } \\
\text { pollutants emitted, technical } \\
\text { options score, and evaporation } \\
\text { treatment costs for a single } \\
\text { water treatment plant }\end{array}$ & 2007 & {$[62]$} \\
\hline Italy & $\begin{array}{c}\text { Brancaccio, } \\
\text { Carini, and } \\
\text { Termini Imerese }\end{array}$ & & $\begin{array}{l}\text { Automotive sector } \\
\text { and neighbouring } \\
\text { companies }\end{array}$ & $\begin{array}{l}\text { Plastic sub } \\
\text { products and } \\
\text { scraps }\end{array}$ & & $\begin{array}{c}\text { Questionnaire data survey to } \\
\text { organizations and interviews, } \\
\text { life cycle assessment }\end{array}$ & 2010 & [63] \\
\hline Italy & $\begin{array}{l}\text { Val di Sangro } \\
\text { Industrial Area, } \\
\text { Abruzzo Region }\end{array}$ & 19 & Motorcycle industry & & $\begin{array}{l}\text { Collective management } \\
\text { of scraps: pre-treatment } \\
\text { centre and on-site } \\
\text { management of the } \\
\text { end-of-life of products } \\
\text { manufactured by the } \\
\text { industrial network }\end{array}$ & $\begin{array}{l}\text { On-site data collection, } \\
\text { performed by using } \\
\text { semi-structured questionnaires, } \\
\text { direct, and e-mail interviews of } \\
\text { the leaders, site visits, and } \\
\text { focus groups }\end{array}$ & 2014 & {$[64]$} \\
\hline Italy & $\begin{array}{l}\text { Fucino upland, } \\
\text { Abruzzo Region }\end{array}$ & & $\begin{array}{l}\text { Agri-food companies, } \\
\text { paper mill, PVC } \\
\text { sewer pipes producer } \\
\text { company, pellets and } \\
\text { plywood panels } \\
\text { producer company }\end{array}$ & $\begin{array}{l}\text { Paper and } \\
\text { cardboard wastes, } \\
\text { plastic wastes, } \\
\text { and wood wastes }\end{array}$ & $\begin{array}{l}\text { Common local } \\
\text { recycling platform }\end{array}$ & $\begin{array}{l}\text { On-site survey; face-to-face } \\
\text { non-structured interviews with } \\
\text { the head of the provincial } \\
\text { Association of Agricultural } \\
\text { Producers and semi-structured } \\
\text { interviews with the technical } \\
\text { staff by telephone or e-mail }\end{array}$ & 2015 & {$[65]$} \\
\hline
\end{tabular}


Table A1. Cont.

\begin{tabular}{|c|c|c|c|c|c|c|c|c|}
\hline Country & Location/Region & $\mathrm{NE}^{1}$ & Activity & Waste/By-Products & $\begin{array}{c}\text { Infrastructure } \\
\text { Sharing/Joint } \\
\text { Provision of Services }\end{array}$ & Method & $\begin{array}{l}\text { Publication } \\
\text { Year }\end{array}$ & Refs. \\
\hline Italy & Emilia-Romagna & & $\begin{array}{l}\text { Agrofood sector, industries } \\
\text { with the technologies able } \\
\text { to transform and enhance } \\
\text { the by-products, and } \\
\text { companies reusing } \\
\text { by-products }\end{array}$ & $\begin{array}{l}\text { Agro-food waste, mud, } \\
\text { packaging, waste from } \\
\text { construction and demolition, } \\
\text { textile waste, waste from } \\
\text { petroleum refining and } \\
\text { natural gas purification, } \\
\text { waste from wood processing, } \\
\text { and digested }\end{array}$ & & $\begin{array}{l}\text { Interviews with private } \\
\text { companies and public } \\
\text { administrators, guided } \\
\text { collective discussion, visits to } \\
\text { laboratories, and conferences }\end{array}$ & 2015 & [53] \\
\hline Italy & $\begin{array}{c}\text { Catania and } \\
\text { Siracusa } \\
\text { districts, Sicily }\end{array}$ & & $\begin{array}{l}\text { Agriculture, forestry and } \\
\text { fishing, manufacturing, } \\
\text { electricity, gas, steam and } \\
\text { air conditioning supply, } \\
\text { water supply; sewerage, } \\
\text { waste management and } \\
\text { remediation activities, } \\
\text { construction, wholesale } \\
\text { and retail trade, repair of } \\
\text { motor vehicles and } \\
\text { motorcycles, transportation } \\
\text { and storage, information } \\
\text { and communication, } \\
\text { professional, scientific and } \\
\text { technical activities, } \\
\text { administrative and support } \\
\text { service activities, education, } \\
\text { human health and social } \\
\text { work activities, and other } \\
\text { service activities }\end{array}$ & $\begin{array}{l}\text { Water, fuels, materials from } \\
\text { agriculture, electrical and } \\
\text { electronic compounds, } \\
\text { municipal wastewater } \\
\text { treatment sludge, industrial } \\
\text { sludge, packaging, wood and } \\
\text { wood products, metals and } \\
\text { metal products, construction } \\
\text { minerals, industrial minerals, } \\
\text { mineral waste oils, plastics } \\
\text { and plastic products, } \\
\text { foodstuffs, inorganic } \\
\text { chemicals, organic chemicals, } \\
\text { products from livestock and } \\
\text { fisheries, construction, } \\
\text { demolition, excavation } \\
\text { materials, paper and } \\
\text { paperboard, sands from } \\
\text { separation processes, glass } \\
\text { and glass products }\end{array}$ & $\begin{array}{l}\text { Energy, equipment, } \\
\text { expertise, consultancy } \\
\text { and services, logistics } \\
\text { and transportation }\end{array}$ & $\begin{array}{l}\text { Invitation emails and phone } \\
\text { calls; meeting tables }\end{array}$ & 2016 & [66] \\
\hline Italy & Brescia & 12 & $\begin{array}{l}\text { Multi-utility company, } \\
\text { steelmakers, cement } \\
\text { producer, waste treatment } \\
\text { and biomass power station, } \\
\text { woodchips producer, car } \\
\text { fluff treatment, asphalt } \\
\text { producer, caviar producer, } \\
\text { the municipality and public } \\
\text { service facilities }\end{array}$ & $\begin{array}{l}\text { Black slag, car fluff, dust, mill } \\
\text { scales, pallets and waste } \\
\text { wood, sludge, and energy } \\
\text { (electrical and thermal) }\end{array}$ & & SWOT analysis & 2017 & [67] \\
\hline
\end{tabular}


Table A1. Cont.

\begin{tabular}{|c|c|c|c|c|c|c|c|c|}
\hline Country & Location/Region & $\mathrm{NE}^{1}$ & Activity & Waste/By-Products & $\begin{array}{c}\text { Infrastructure } \\
\text { Sharing/Joint } \\
\text { Provision of Services }\end{array}$ & Method & $\begin{array}{l}\text { Publication } \\
\text { Year }\end{array}$ & Refs. \\
\hline Italy & Brescia & 2 & $\begin{array}{l}\text { Energy-intensive factory } \\
\text { (with forging processes), } \\
\text { and greenhouse } \\
\text { horticulture installations }\end{array}$ & Carbon dioxide emissions & & $\begin{array}{l}\text { Economic model: increase of } \\
\text { revenues due to the } \mathrm{CO}_{2} \\
\text { enrichment process, savings } \\
\text { due to the reduction of } \mathrm{CO}_{2} \\
\text { emissions in the industrial } \\
\text { installation, and savings due to } \\
\text { avoided natural gas } \\
\text { consumptions (used in } \\
\text { traditional } \mathrm{CO}_{2} \text { enrichment } \\
\text { methods) }\end{array}$ & 2018 & {$[35]$} \\
\hline Italy & $\begin{array}{c}\text { Province of } \\
\text { Pescara, } \\
\text { Abruzzo Region }\end{array}$ & & $\begin{array}{l}\text { Crop/vegetable production, } \\
\text { cattle breeding, } \\
\text { greenhouses, fish farming, } \\
\text { industrial processing, } \\
\text { production of pellets, urban } \\
\text { furniture production, road } \\
\text { works company, residential } \\
\text { system, and waste and } \\
\text { energy system (thermal } \\
\text { treatment plant, } \\
\text { composting, biofuels } \\
\text { production, recovery and } \\
\text { recycling activities, } \\
\text { biomass/biogas energy } \\
\text { plant, and wastewater } \\
\text { treatment) }\end{array}$ & $\begin{array}{c}\text { Vegetable wastes, plant } \\
\text { waste, vegetable waste (dry } \\
\text { fraction, e.g. from pruning, } \\
\text { sawdust), differentiated } \\
\text { residential waste (aluminium, } \\
\text { steel, glass, paper, plastics), } \\
\text { construction and demolition } \\
\text { waste, heat waste, hot water } \\
\text { or steam, wastewater, and } \\
\text { industrial waste }\end{array}$ & & $\begin{array}{l}\text { Qualitative analysis of the } \\
\text { scientific literature and } \\
\text { secondary data and critical } \\
\text { analysis }\end{array}$ & 2017 & [11] \\
\hline Italy & Marche Region & 3 & $\begin{array}{c}\text { Waste electrical and } \\
\text { electronic equipment } \\
\text { treatment centre, material } \\
\text { recycler and a compound } \\
\text { producer }\end{array}$ & $\begin{array}{l}\text { Plastics from electrical cables } \\
\text { insulation }\end{array}$ & & $\begin{array}{l}\text { Web platform. Economic } \\
\text { assessments. Life cycle } \\
\text { assessment methodology }\end{array}$ & 2018 & {$[38]$} \\
\hline Sweden & $\begin{array}{l}\text { Small town in } \\
\text { southern } \\
\text { Sweden }\end{array}$ & & $\begin{array}{l}\text { Sawmill, paper mill, paper } \\
\text { processing industry, local } \\
\text { energy service company, } \\
\text { the municipality, ecocycle } \\
\text { company, and local waste } \\
\text { management company }\end{array}$ & $\begin{array}{l}\text { Waste heat, sawdust, bark, } \\
\text { woodchips, ashes, sewage } \\
\text { sludge, organic waste } \\
\text { materials, paper residues, } \\
\text { and fibre residues }\end{array}$ & & $\begin{array}{l}\text { Conversational and } \\
\text { open-ended interviews and } \\
\text { group discussion, direct } \\
\text { observation and participation } \\
\text { at the sites, mass and heat } \\
\text { balances over the system }\end{array}$ & 2005 & {$[68]$} \\
\hline
\end{tabular}


Table A1. Cont.

\begin{tabular}{|c|c|c|c|c|c|c|c|c|}
\hline Country & Location/Region & $\mathrm{NE}^{1}$ & Activity & Waste/By-Products & $\begin{array}{c}\text { Infrastructure } \\
\text { Sharing/Joint } \\
\text { Provision of Services }\end{array}$ & Method & $\begin{array}{l}\text { Publication } \\
\text { Year }\end{array}$ & Refs. \\
\hline Sweden & & 4 & $\begin{array}{l}\text { Chemical pulp mill, } \\
\text { sawmill, biofuel upgrading } \\
\text { plant, and district heating } \\
\text { system }\end{array}$ & & & $\begin{array}{l}\text { Method for analysis of } \\
\text { industrial energy systems } \\
\text { (MIND method), based on } \\
\text { mixed integer linear } \\
\text { programming }\end{array}$ & 2008 & [69] \\
\hline Sweden & & 4 & $\begin{array}{l}\text { Chemical pulp mill, } \\
\text { sawmill, biofuel upgrading } \\
\text { plant and district heating } \\
\text { system }\end{array}$ & $\begin{array}{c}\text { Bark, steam, heat, chips, and } \\
\text { sawdust }\end{array}$ & & $\begin{array}{l}\text { Method for analysis of } \\
\text { industrial energy systems } \\
\text { (MIND method) based on } \\
\text { mixed integer linear } \\
\text { programming. Commercial } \\
\text { optimization solver (CPLEX). } \\
\text { Assessment of } \mathrm{CO}_{2} \text { emissions } \\
\text { from biofuel and electricity for } \\
\text { different accounting models } \\
\text { (marginal coal, marginal new } \\
\text { technology and average } \\
\text { Swedish production) }\end{array}$ & 2008 & [70] \\
\hline Sweden & $\begin{array}{l}\text { Luleå, Borlänge, } \\
\text { Finspång, } \\
\text { Sandviken }\end{array}$ & & $\begin{array}{l}\text { Iron and steel industry } \\
\text { (integrated steel plant and } \\
\text { scrap-based steel plant), } \\
\text { pulp and paper industries, } \\
\text { district heating consumers, } \\
\text { and district heating } \\
\text { distributor }\end{array}$ & $\begin{array}{l}\text { Excess heat and gasified } \\
\text { biomass residues }\end{array}$ & & System perspective evaluation & 2011 & [71] \\
\hline Sweden & $\begin{array}{c}\text { All } 290 \\
\text { municipalities }\end{array}$ & & $\begin{array}{l}\text { Agriculture, forestry, and } \\
\text { fishing; mining and } \\
\text { quarrying; manufacturing; } \\
\text { electricity, gas, steam and } \\
\text { air conditioning supply; } \\
\text { water supply; sewerage, } \\
\text { waste management and } \\
\text { remediation activities; and } \\
\text { construction }\end{array}$ & & & $\begin{array}{l}\text { Looplocal method, life cycle } \\
\text { inventory }\end{array}$ & 2015 & [72] \\
\hline
\end{tabular}


Table A1. Cont.

\begin{tabular}{|c|c|c|c|c|c|c|c|c|}
\hline Country & Location/Region & $\mathrm{NE}^{1}$ & Activity & Waste/By-Products & $\begin{array}{c}\text { Infrastructure } \\
\text { Sharing/Joint } \\
\text { Provision of Services }\end{array}$ & Method & $\begin{array}{c}\text { Publication } \\
\text { Year }\end{array}$ & Refs. \\
\hline Sweden & Västra Götaland & & $\begin{array}{l}\text { Waste incinerators, steel } \\
\text { mill, cement industry, } \\
\text { manufacture of concrete } \\
\text { products industries, } \\
\text { polymer industry, algae } \\
\text { production, power stations, } \\
\text { refineries, paper and pulp } \\
\text { industry, municipal and } \\
\text { industrial wastewater } \\
\text { treatment plants, biogas } \\
\text { upgrading plants, } \\
\text { greenhouse operator, and } \\
\text { methanol production unit }\end{array}$ & $\begin{array}{c}\mathrm{CO}_{2} \text {, fly ash, bottom ash, } \\
\text { steel slag, municipal solid } \\
\text { waste ash, wastewater, and } \\
\text { hydrogen }\end{array}$ & & $\begin{array}{l}\text { Top-down approach with three } \\
\text { consecutive steps: generic } \\
\text { matrix of } \mathrm{CO}_{2} \text { sources, generic } \\
\text { matrix of } \mathrm{CO}_{2} \text { receivers, and } \\
\text { matching the sources with the } \\
\text { receivers at regional level }\end{array}$ & 2017 & [73] \\
\hline France & $\begin{array}{l}\text { Territoire de la } \\
\text { Côte Ouest, } \\
\text { Réunion Island }\end{array}$ & & $\begin{array}{l}\text { Agricultural activities, } \\
\text { fertilizer production facility, } \\
\text { market gardeners, and } \\
\text { complementation and } \\
\text { granulation factory }\end{array}$ & $\begin{array}{c}\text { Livestock wastes (pig } \\
\text { manure, droppings from } \\
\text { broiler chickens, and laying } \\
\text { hens) and shredded green } \\
\text { waste }\end{array}$ & & $\begin{array}{l}\text { 'Follow the Technology' } \\
\text { method and Companion } \\
\text { Modelling or Commod }\end{array}$ & 2017 & {$[74]$} \\
\hline France & & 7 & & Waste/unused energy & & $\begin{array}{l}\text { Mixed integer linear } \\
\text { programming; single objective } \\
\text { model to minimize the total } \\
\text { cost, single objective model to } \\
\text { minimize the total } \\
\text { environmental impact and } \\
\text { bi-objective model to minimize } \\
\text { the total cost and total } \\
\text { environmental impact; direct } \\
\text { method to quantify the heat } \\
\text { energy of firms; key process } \\
\text { indicators: demand } \\
\text { satisfaction, weighted demand } \\
\text { satisfaction, supply utilization, } \\
\text { and carbon tax reduction; } \\
\text { uncertainty evaluation using } \\
\text { sensitivity analysis; } \\
\text { multi-objective model and } \\
\text { Pareto front analysis; weighted } \\
\text { sum method }\end{array}$ & 2018 & [75] \\
\hline
\end{tabular}


Table A1. Cont.

\begin{tabular}{|c|c|c|c|c|c|c|c|c|}
\hline Country & Location/Region & $\mathrm{NE}^{1}$ & Activity & Waste/By-Products & $\begin{array}{c}\text { Infrastructure } \\
\text { Sharing/Joint } \\
\text { Provision of Services }\end{array}$ & Method & $\begin{array}{c}\text { Publication } \\
\text { Year }\end{array}$ & Refs \\
\hline France & $\begin{array}{c}\text { Gravelines, } \\
\text { Penly, } \\
\text { Fessenheim, } \\
\text { Tricastin, St } \\
\text { Alban, Nogent } \\
\text { sur Seine, } \\
\text { Civaux, St } \\
\text { Laurent des } \\
\text { Eaux, Bugey, } \\
\text { Chinon, Blayais, } \\
\text { Chooz, } \\
\text { Cattenom, } \\
\text { Flamanville, } \\
\text { Paluel, Golfech }\end{array}$ & & $\begin{array}{l}\text { Nuclear plants, agri-food } \\
\text { industries (fruit and } \\
\text { vegetables, dairy products, } \\
\text { starch products, sugar } \\
\text { refinery and malt } \\
\text { production), wood, pulp } \\
\text { and paper (wood panels, } \\
\text { pulp and paper, card and } \\
\text { paper and corrugated card), } \\
\text { chemical and } \\
\text { pharmaceutical industries } \\
\text { (dyes and pigments, other } \\
\text { basic organic chemicals and } \\
\text { basic pharmaceutical } \\
\text { products) and plastic, } \\
\text { rubber and other } \\
\text { elastomers (basic plastic } \\
\text { materials and synthetic } \\
\text { rubber) }\end{array}$ & Steam & & $\begin{array}{l}\text { Average energy intensity in a } \\
\text { subsector, production value, } \\
\text { average heat consumption of a } \\
\text { factory in a subsector, and heat } \\
\text { consumed by a factory in a } \\
\text { subsector; spatial mapping } \\
\text { methods and geographical } \\
\text { information system; } \\
\text { techno-economic model: } \\
\text { energy consumption } \\
\text { sub-model (maximum thermal } \\
\text { power required), energy } \\
\text { generation sub-model } \\
\text { (infrastructure cost of a } \\
\text { combined heat and power } \\
\text { upgrade, required cost, and } \\
\text { additional } \mathrm{CO}_{2} \text { emissions to } \\
\text { compensate for power } \\
\text { generation losses), and energy } \\
\text { distribution sub-model (pipe } \\
\text { diameter, heat loss assessment, } \\
\text { pumping cost, } \mathrm{CO}_{2} \text { assessment, } \\
\text { pipeline installation cost, and } \\
\text { annual rental cost); linear } \\
\text { programming problem }\end{array}$ & 2018 & [36] \\
\hline France & $\begin{array}{l}\text { Salaise-sur-Sanne } \\
\text { and Sablons }\end{array}$ & & $\begin{array}{l}\text { Chemical, recycling and } \\
\text { raw material } \\
\text { transformation, and urban } \\
\text { areas }\end{array}$ & Industrial waste & $\begin{array}{l}\text { Shared infrastructures } \\
\text { (for energy supply, } \\
\text { cogeneration, solid } \\
\text { waste treatment, } \\
\text { reclaimed water, etc.) }\end{array}$ & SWOT analysis & 2018 & [76] \\
\hline Finland & Oulu & & $\begin{array}{l}\text { Steel, pulp and paper } \\
\text { industry, cement products } \\
\text { manufacturer, soil } \\
\text { amendment, soil } \\
\text { fertilization, and } \\
\text { pellets/ameliorants } \\
\text { manufacturers }\end{array}$ & $\begin{array}{l}\text { Granulated blast furnace } \\
\text { slag, ashes, fibre clay, and } \\
\text { alkaline residues }\end{array}$ & & $\begin{array}{l}\text { Literature review and study of } \\
\text { a spectrum of residue-based } \\
\text { product concepts for further } \\
\text { research }\end{array}$ & 2010 & [77] \\
\hline
\end{tabular}


Table A1. Cont.

\begin{tabular}{|c|c|c|c|c|c|c|c|c|}
\hline Country & Location/Region & $\mathrm{NE}^{1}$ & Activity & Waste/By-Products & $\begin{array}{c}\text { Infrastructure } \\
\text { Sharing/Joint } \\
\text { Provision of Services }\end{array}$ & Method & $\begin{array}{c}\text { Publication } \\
\text { Year }\end{array}$ & Refs. \\
\hline Finland & & & $\begin{array}{c}\text { Waste management, } \\
\text { wastewater treatment, } \\
\text { municipality, biogas } \\
\text { producer, crop farm, and } \\
\text { animal farm }\end{array}$ & $\begin{array}{l}\text { Sewage sludge, manure, } \\
\text { organic household waste, } \\
\text { and digestate }\end{array}$ & & $\begin{array}{l}\text { Interviews with companies, } \\
\text { collaborative research } \\
\text { approach, replication approach }\end{array}$ & 2015 & [78] \\
\hline Finland & & & $\begin{array}{l}\text { Horse industry, agriculture } \\
\text { and pellet production } \\
\text { industry }\end{array}$ & Horse manure & & Survey sent to companies & 2018 & [79] \\
\hline Greece & Viotia & & $\begin{array}{c}\text { Aluminium casting } \\
\text { company, and companies } \\
\text { which have capacities to } \\
\text { buy and use aluminium } \\
\text { waste }\end{array}$ & Aluminium waste & & $\begin{array}{l}\text { Ontology engineering } \\
\text { approach-eSymbiosis. } \\
\text { Metrics for industrial } \\
\text { symbiosis benefits: Economic: } \\
\text { cost savings to business, and } \\
\text { additional sales to business; } \\
\text { Environmental: landfill } \\
\text { diversion, } \mathrm{CO}_{2} \text { reduction, } \\
\text { virgin raw materials saved, } \\
\text { hazardous waste eliminated, } \\
\text { and water savings; Social: jobs } \\
\text { created, and jobs saved }\end{array}$ & 2015 & {$[80]$} \\
\hline Greece & Pili & & $\begin{array}{l}\text { Power plant, furniture } \\
\text { manufactures, sewage } \\
\text { treatment plant, concrete } \\
\text { industry, and food } \\
\text { industries }\end{array}$ & $\begin{array}{l}\text { Sawdust, ash, whey of cheese } \\
\text { dairies, and salad residues }\end{array}$ & $\begin{array}{l}\text { Utility sharing: } \\
\text { autonomous water } \\
\text { supply system }\end{array}$ & $\begin{array}{l}\text { Methodology proposed and } \\
\text { implemented to determine the } \\
\text { most appropriate location and } \\
\text { bioclimatic criteria }\end{array}$ & 2017 & [81] \\
\hline Greece & Achaia & & $\begin{array}{l}\text { Olive-oil production } \\
\text { facility, biopolymers } \\
\text { (PHAs) production facility, } \\
\text { and plastics production } \\
\text { facility }\end{array}$ & $\begin{array}{c}\text { Olive mill wastewater and } \\
\text { PHAs }\end{array}$ & & $\begin{array}{l}\text { Telephone interviews, visits, } \\
\text { and face-to-face interviews }\end{array}$ & 2017 & [82] \\
\hline
\end{tabular}


Table A1. Cont.

\begin{tabular}{|c|c|c|c|c|c|c|c|c|}
\hline Country & Location/Region & $\mathrm{NE}^{1}$ & Activity & Waste/By-Products & $\begin{array}{c}\text { Infrastructure } \\
\text { Sharing/Joint } \\
\text { Provision of Services }\end{array}$ & Method & $\begin{array}{c}\text { Publication } \\
\text { Year }\end{array}$ & Refs. \\
\hline Germany & Rhine-Neckar & & & & $\begin{array}{c}\text { Network structure, } \\
\text { waste management } \\
\text { software, waste } \\
\text { analyser software, and } \\
\text { intranet platform }\end{array}$ & On-site surveys & 2004 & [83] \\
\hline Germany & $\begin{array}{l}\text { Central } \\
\text { Germany }\end{array}$ & & $\begin{array}{c}\text { (i) Lignocellulosic } \\
\text { biorefinery plant, and } \\
\text { chipping; (ii) lignocellulosic } \\
\text { biorefinery plant, chipping, } \\
\text { refinery plant and waste } \\
\text { wood-fired CHP units; (iii) } \\
\text { lignocellulosic biorefinery } \\
\text { plant, waste wood-fired } \\
\text { CHP units, refiner plant, } \\
\text { chipping, bio-based resins } \\
\text { and adhesives, wood panel } \\
\text { production, composite } \\
\text { manufacturing, and } \\
\text { engineered wood products }\end{array}$ & $\begin{array}{l}\text { (i) Beech wood chips from } \\
\text { industrial residues; (ii) waste } \\
\text { wood, bark residues, and } \\
\text { sawmill by-products; (iii) } \\
\text { residues from industrial } \\
\text { wood }\end{array}$ & & $\begin{array}{l}\text { Communications and site } \\
\text { visits, life cycle assessment and } \\
\text { CML } 2013 \text { method, indicator } \\
\text { assessment for the CML impact } \\
\text { categories and relative } \\
\text { advantage or disadvantage of } \\
\text { the environmental impact }\end{array}$ & 2018 & [84] \\
\hline Scotland & $\begin{array}{c}\text { Perth and } \\
\text { Kinross }\end{array}$ & & $\begin{array}{l}\text { Sawmill, pellet mill, and } \\
\text { combined heat and power } \\
\text { plant }\end{array}$ & $\begin{array}{l}\text { Milling wood residues, } \\
\text { sawdust, and residual wood } \\
\text { fibre }\end{array}$ & & $\begin{array}{l}\text { Questionnaires to estate } \\
\text { owners, forestry consultants, } \\
\text { wood processors and } \\
\text { equipment suppliers, and five } \\
\text { focus groups with } 45 \text { residents }\end{array}$ & 2007 & [85] \\
\hline
\end{tabular}


Table A1. Cont.

\begin{tabular}{|c|c|c|c|c|c|c|c|c|}
\hline Country & Location/Region & $\mathrm{NE}^{1}$ & Activity & Waste/By-Products & $\begin{array}{c}\text { Infrastructure } \\
\text { Sharing/Joint } \\
\text { Provision of Services }\end{array}$ & Method & $\begin{array}{l}\text { Publication } \\
\text { Year }\end{array}$ & Refs. \\
\hline Scotland & $\begin{array}{l}\text { Perth and } \\
\text { Kinross }\end{array}$ & & $\begin{array}{l}\text { Forest industry, sawmill, } \\
\text { combined heat and power } \\
\text { plant, and wood pellet mill }\end{array}$ & Woodchips and sawdust & & $\begin{array}{l}\text { Questionnaire survey of } \\
\text { representatives from the wood } \\
\text { fuel supply chain and an } \\
\text { attitude survey of a sample of } \\
\text { off-mains gas residents }\end{array}$ & 2007 & [43] \\
\hline Spain & Besaya & 80 & $\begin{array}{l}\text { Commerce, repair of motor } \\
\text { vehicles and motorcycles, } \\
\text { manufacture of basic } \\
\text { metals and of fabricated } \\
\text { metal products, } \\
\text { construction, manufacture } \\
\text { of mechanical machinery } \\
\text { and equipment, } \\
\text { manufacture of paper and } \\
\text { paper products, printing } \\
\text { and reproduction of } \\
\text { recorded media, } \\
\text { manufacture of other } \\
\text { non-metallic mineral } \\
\text { products, other } \\
\text { manufacture activities, } \\
\text { manufacture of food } \\
\text { products, beverages and } \\
\text { tobacco products, transport } \\
\text { and storage, manufacture } \\
\text { of chemicals and chemical } \\
\text { products, manufacture of } \\
\text { wood and of products of } \\
\text { wood and cork, } \\
\text { manufacture of rubber and } \\
\text { plastic products, and } \\
\text { manufacture of transport } \\
\text { equipment }\end{array}$ & $\begin{array}{l}\text { Waste oil, used metal } \\
\text { containers, used coolants, ink } \\
\text { slag, waste sand, rubble and } \\
\text { waste material from } \\
\text { construction, solid wastes } \\
\text { (plastic, discarded tires, } \\
\text { wood cuttings and slag from } \\
\text { varnishes and paint), waste } \\
\text { products from oils and grease } \\
\text { (food, machining, hydraulics, } \\
\text { motor, separators), } \\
\text { lime-based waste products } \\
\text { (plasters and slag), waste } \\
\text { products from plastic (plastic, } \\
\text { shavings and burns), waste } \\
\text { products from ferrous metals } \\
\text { (ferrous metals, ferrous metal } \\
\text { filings and shavings, scrap } \\
\text { metal), waste products from } \\
\text { glass, waste products from } \\
\text { lead batteries, waste } \\
\text { products from used tires and } \\
\text { slag, waste products from } \\
\text { catalysers, waste products } \\
\text { from wood without } \\
\text { hazardous substances, waste } \\
\text { products from ceramic } \\
\text { materials (roof tiles, ceramic } \\
\text { materials, bricks), waste } \\
\text { products from plaster, waste } \\
\text { products from cellulose, and } \\
\text { waste products from food }\end{array}$ & $\begin{array}{l}\text { Joint waste } \\
\text { management: central } \\
\text { areas for communal } \\
\text { waste storage, shared } \\
\text { use of waste storage } \\
\text { space, shared transport } \\
\text { of waste to municipal } \\
\text { management points, } \\
\text { joint management of } \\
\text { waste products for sale } \\
\text { or exchange, joint } \\
\text { management of waste } \\
\text { by an external agent, } \\
\text { and shared use of waste } \\
\text { treatment and recovery } \\
\text { installations }\end{array}$ & $\begin{array}{l}\text { Questionnaires and visits to } \\
\text { various companies }\end{array}$ & 2015 & {$[86]$} \\
\hline
\end{tabular}


Table A1. Cont.

\begin{tabular}{|c|c|c|c|c|c|c|c|c|}
\hline Country & Location/Region & $\mathrm{NE}^{1}$ & Activity & Waste/By-Products & $\begin{array}{c}\text { Infrastructure } \\
\text { Sharing/Joint } \\
\text { Provision of Services }\end{array}$ & Method & $\begin{array}{l}\text { Publication } \\
\text { Year }\end{array}$ & Refs. \\
\hline Spain & $\begin{array}{l}\text { Cartes, } \\
\text { Cantabria } \\
\text { autonomous } \\
\text { community }\end{array}$ & 25 & $\begin{array}{l}\text { Automotive industry, } \\
\text { metallurgy and } \\
\text { manufacturing, building } \\
\text { industry and other various } \\
\text { manufacturing industries }\end{array}$ & $\begin{array}{l}\text { Edible oil and fat, paper and } \\
\text { cardboard packaging, etc. }\end{array}$ & $\begin{array}{l}\text { Service or } \\
\text { infrastructure: common } \\
\text { transport and waste } \\
\text { collection and waste } \\
\text { treatment services }\end{array}$ & $\begin{array}{l}\text { Relational database } \\
\text { management system, } \\
\text { georeferencing, geographic } \\
\text { information systems, and } \\
\text { application programming } \\
\text { interface; SymbioSyS tool }\end{array}$ & 2017 & [87] \\
\hline Lithuania & Jonava & & $\begin{array}{c}\text { Nitrogen fertilizers and } \\
\text { chemical products } \\
\text { manufacturer company, } \\
\text { cattle farms, } \\
\text { slaughterhouses, municipal } \\
\text { wastewater treatment plant, } \\
\text { bio-fuel production and/or } \\
\text { solid recovered fuel } \\
\text { production in pellet form } \\
\text { company, administration, } \\
\text { and special purpose } \\
\text { facilities }\end{array}$ & $\begin{array}{c}\text { Waste heat energy, } \\
\text { biodegradable waste } \\
\text { (manure and slurry), and } \\
\text { sewage sludge }\end{array}$ & & $\begin{array}{l}\text { Material flow analysis, material } \\
\text { and energy balances of each } \\
\text { processes, fuel and energy } \\
\text { balances of energy production } \\
\text { processes, evaluation of } \\
\text { environmental indicators } \\
\text { (relative environmental } \\
\text { indicators, energy savings, loss } \\
\text { of waste heat energy and } \\
\text { volume of carbon dioxide } \\
\text { emissions) and comparative } \\
\text { analysis; feasibility analysis } \\
\text { (technical, environmental and } \\
\text { economic evaluation) }\end{array}$ & 2016 & [88] \\
\hline Lithuania & & & $\begin{array}{l}\text { Nitrogen fertilizer } \\
\text { production company, cattle } \\
\text { farms and slaughterhouses }\end{array}$ & Biodegradable waste & & $\begin{array}{l}\text { Indicators: geostrategic supply } \\
\text { risk and economic importance }\end{array}$ & 2018 & [89] \\
\hline $\begin{array}{l}\text { United } \\
\text { Kingdom }\end{array}$ & & & $\begin{array}{l}\text { Bio-refineries, agricultural } \\
\text { production, and forestry }\end{array}$ & $\begin{array}{c}\text { Lignocellulose and } \\
\text { municipal solid waste } \\
\text { (organic food and packaging) }\end{array}$ & & & 2008 & [90] \\
\hline Norway & Mongstad & 6 & $\begin{array}{c}\text { Refinery plant, coal } \\
\text { gasification, combined heat } \\
\text { and power plant, } \\
\text { production of synthetic } \\
\text { transportation fuels, carbon } \\
\text { capture and utilization, and } \\
\text { aquaculture }\end{array}$ & $\mathrm{CO}_{2}$ and waste heat & & $\begin{array}{l}\text { Mass and energy balance } \\
\text { assessment, material and } \\
\text { energy flow analysis, carbon } \\
\text { and hydrogen flow analysis, } \\
\mathrm{CO}_{2} \text { emission evaluation, and } \\
\text { sensitivity analysis; hierarchy } \\
\text { analysis method }\end{array}$ & 2008 & [91] \\
\hline
\end{tabular}


Table A1. Cont.

\begin{tabular}{|c|c|c|c|c|c|c|c|c|}
\hline Country & Location/Region & $\mathrm{NE}^{1}$ & Activity & Waste/By-Products & $\begin{array}{c}\text { Infrastructure } \\
\text { Sharing/Joint } \\
\text { Provision of Services }\end{array}$ & Method & $\begin{array}{l}\text { Publication } \\
\text { Year }\end{array}$ & Refs. \\
\hline England & $\begin{array}{c}\text { Thames estuary, } \\
\text { Port of Bristol, } \\
\text { east } \\
\text { Birmingham, } \\
\text { Mersey estuary, } \\
\text { and Teesside }\end{array}$ & & & & Utilities-sharing & $\begin{array}{l}\text { Habitat Suitability Mapping: } \\
\text { Habitat Suitability Index, } \\
\text { Geographic Information } \\
\text { System model, Symbiosis } \\
\text { Suitability Index, Symbiosis } \\
\text { Suitability Map, Symbiosis } \\
\text { Suitability Index Variables and } \\
\text { Variable Aggregation, and } \\
\text { Multi-Criteria-Evaluation } \\
\text { mapping. Sensitivity analysis }\end{array}$ & 2012 & [92] \\
\hline $\begin{array}{l}\text { Finland and } \\
\text { Sweden }\end{array}$ & Gulf of Bothnia & 7 & $\begin{array}{l}\text { Carbon steel mills, stainless } \\
\text { steel mill, zinc plant, and iron } \\
\text { regeneration plant }\end{array}$ & $\begin{array}{l}\text { Iron and zinc dusts and } \\
\text { scales, jarosite, direct } \\
\text { reduced iron, zinc oxide, and } \\
\text { manganese dregs }\end{array}$ & & $\begin{array}{l}\text { Strengths and weaknesses } \\
\text { assessment in national and } \\
\text { European Union waste } \\
\text { regulation and common pool } \\
\text { resource management analysis }\end{array}$ & 2012 & [93] \\
\hline Latvia & & 2 & Brewery and biogas plant & Brewer's spent grain & & $\begin{array}{l}\text { Site visits. Cumulative } \\
\text { intensity indicator of a } \\
\text { considered factor (energy } \\
\text { consumption and } \mathrm{CO}_{2} \\
\text { emission generation) }\end{array}$ & 2015 & [94] \\
\hline $\begin{array}{l}\text { European } \\
\text { country }\end{array}$ & & & $\begin{array}{l}\text { Sugar-beet production, } \\
\text { microalgae cultivations, and } \\
\text { agro-energy sector }\end{array}$ & $\mathrm{CO}_{2}$ and water effluents & & Concept analysis & 2015 & [95] \\
\hline Romania & $\begin{array}{l}\text { Botosani and } \\
\text { Neamt }\end{array}$ & & $\begin{array}{l}\text { Manufacture of profiles and } \\
\text { fittings from steel, manufacture } \\
\text { of ceramic sanitary fixtures, } \\
\text { institutions and small } \\
\text { businesses (tourist pensions, } \\
\text { offices, kindergartens, etc.), } \\
\text { construction of residential and } \\
\text { non-residential buildings, } \\
\text { supply of steam and air } \\
\text { conditioning, manufacture of } \\
\text { garments, manufacture of } \\
\text { furniture, agriculture, } \\
\text { collection, purification and } \\
\text { distribution of water, and retail } \\
\text { sale of audio/video equipment } \\
\text { in specialized stores }\end{array}$ & Hot gas & $\begin{array}{l}\text { Infrastructure for } \\
\text { utilities and supply } \\
\text { process optimization }\end{array}$ & $\begin{array}{l}\text { Interviews with the board, or } \\
\text { the manager, of each company }\end{array}$ & 2017 & [44] \\
\hline
\end{tabular}


Table A1. Cont.

\begin{tabular}{|c|c|c|c|c|c|c|c|c|}
\hline Country & Location/Region & $\mathrm{NE}^{1}$ & Activity & Waste/By-Products & $\begin{array}{c}\text { Infrastructure } \\
\text { Sharing/Joint } \\
\text { Provision of Services }\end{array}$ & Method & $\begin{array}{c}\text { Publication } \\
\text { Year }\end{array}$ & Refs. \\
\hline \multicolumn{9}{|c|}{ Asia } \\
\hline China & Handan & & $\begin{array}{c}\text { Heavy chemical industry, } \\
\text { cement industry, coal chemical } \\
\text { industry, iron and steel } \\
\text { industries, building materials } \\
\text { factory, power plant, } \\
\text { agricultural production, } \\
\text { aquaculture, and urban heating }\end{array}$ & $\begin{array}{l}\text { Fly ash, grey water, coal } \\
\text { gangue, PVC profile } \\
\text { processing waste, waste } \\
\text { water, waste heat, and steel } \\
\text { slag }\end{array}$ & & & 2009 & [96] \\
\hline China & $\begin{array}{l}\text { Shanghai City } \\
\text { and Jiangsu } \\
\text { Province }\end{array}$ & & $\begin{array}{l}\text { Cement and steel industries, } \\
\text { urban areas and industrial } \\
\text { sectors }\end{array}$ & $\begin{array}{l}\text { Municipal wastes (plastics } \\
\text { and organic wastes) and } \\
\text { by-products from industries }\end{array}$ & & $\begin{array}{l}\text { Divisia analysis: total output } \\
\text { and energy intensity of each } \\
\text { sector and "Divisia" index } \\
\text { approach; energy demand } \\
\text { analysis and regression } \\
\text { analysis: regression equations } \\
\text { using the Vector } \\
\text { Auto-regression model defined } \\
\text { for forecasting gross regional } \\
\text { product, population, energy } \\
\text { consumption, and cement and } \\
\text { steel production }\end{array}$ & 2011 & [97] \\
\hline China & Jinqiao & & $\begin{array}{l}\text { Central heat-supplying } \\
\text { company, waste treatment } \\
\text { company, enterprises, and } \\
\text { wastewater treatment plant }\end{array}$ & Sewage sludge and used oil & & $\begin{array}{l}\text { Experiments in a laboratory, } \\
\text { life cycle assessment (global } \\
\text { warming potential, } \\
\text { acidification potential, } \\
\text { eutrophication potential and } \\
\text { human toxicity air), total } \\
\text { environmental impact } \\
\text { potential }\end{array}$ & 2011 & [98] \\
\hline China & Yunfu & 3 & $\begin{array}{c}\text { Sulphuric acid industry, } \\
\text { chemical enterprise, and power } \\
\text { plant }\end{array}$ & $\begin{array}{l}\text { Sulphur acid, residue steam } \\
\text { and heat }\end{array}$ & & $\begin{array}{l}\text { Production cost and sale } \\
\text { revenue analysis }\end{array}$ & 2011 & [99] \\
\hline
\end{tabular}


Table A1. Cont.

\begin{tabular}{|c|c|c|c|c|c|c|c|c|}
\hline Country & Location/Region & $\mathrm{NE}^{1}$ & Activity & Waste/By-Products & $\begin{array}{c}\text { Infrastructure } \\
\text { Sharing/Joint } \\
\text { Provision of Services }\end{array}$ & Method & $\begin{array}{c}\text { Publication } \\
\text { Year }\end{array}$ & Refs \\
\hline China & Shenyang & & $\begin{array}{l}\text { Equipment manufacturing } \\
\text { industry and logistics industry }\end{array}$ & & & $\begin{array}{c}\text { Coefficient of industrial } \\
\text { agglomeration degree, Space } \\
\text { Gini coefficient, and Hector } \\
\text { Fanta coefficient of an industry; } \\
\text { logistic model. Index of } \\
\text { competitive analysis; expert } \\
\text { evaluation method; relational } \\
\text { degree taxis }\end{array}$ & 2012 & {$[100]$} \\
\hline China & Guiyang & & $\begin{array}{l}\text { Iron/steel industry, cement } \\
\text { industry, coal chemical } \\
\text { industry, phosphorus chemical } \\
\text { industry, aluminium industry, } \\
\text { power plants, and commercial } \\
\text { and residential area }\end{array}$ & $\begin{array}{c}\text { Steel slag, slag, red mud, } \\
\text { waste steel, waste plastics, } \\
\text { coal gangue, coal fly ash, and } \\
\text { waste heat }\end{array}$ & & $\begin{array}{l}\text { Questionnaires. Material flow } \\
\text { analysis, environmental benefit } \\
\text { evaluation (avoided resource } \\
\text { consumption or avoided waste } \\
\text { emission due to the symbiotic } \\
\text { activity) and } \mathrm{CO}_{2} \text { emission } \\
\text { reduction, effects of resource } \\
\text { efficiency enhancement, cost } \\
\text { reduction }\end{array}$ & 2015 & [39] \\
\hline China & Guiyang & & $\begin{array}{l}\text { Iron/steel industry, coal } \\
\text { chemical industry, phosphorus } \\
\text { chemical industry, aluminium } \\
\text { industry, cement industry, } \\
\text { power plants, and commercial } \\
\text { and residential area }\end{array}$ & $\begin{array}{l}\text { Steel slag, slag, red mud, coal } \\
\text { gangue, coal fly ash, waste } \\
\text { heat, waste steel, and waste } \\
\text { plastics }\end{array}$ & & $\begin{array}{c}\text { Questionnaires, } \\
\text { material/energy flow analysis. } \\
\text { Process life cycle assessment, } \\
\text { avoided consumptions and } \\
\text { emissions for a company, } \mathrm{CO}_{2} \\
\text { emission reduction from the } \\
\text { avoided resource or waste in a } \\
\text { company, hybrid physical } \\
\text { input and monetary output } \\
\text { model hybrid life cycle } \\
\text { assessment model integrating } \\
\text { both process life cycle } \\
\text { assessment and input-output } \\
\text { model, life cycle emissions } \\
\text { change. Scenario analysis. }\end{array}$ & 2016 & [9] \\
\hline
\end{tabular}


Table A1. Cont.

\begin{tabular}{|c|c|c|c|c|c|c|c|c|}
\hline Country & Location/Region & $\mathrm{NE}^{1}$ & Activity & Waste/By-Products & $\begin{array}{c}\text { Infrastructure } \\
\text { Sharing/Joint } \\
\text { Provision of Services }\end{array}$ & Method & $\begin{array}{c}\text { Publication } \\
\text { Year }\end{array}$ & Refs \\
\hline China & $\begin{array}{l}\text { Hangu, Tanggu, } \\
\text { and Dagang } \\
\text { Districts, Tianjin } \\
\text { Municipality }\end{array}$ & & $\begin{array}{c}\text { Seawater desalination plant, } \\
\text { sea salt production, } \\
\text { mariculture, power plant } \\
\text { cooling, Artemia culture, } \\
\text { bromide extraction, and salt } \\
\text { chemical industry }\end{array}$ & $\begin{array}{c}\text { Clarified seawater, } \\
\text { concentrated saline, and } \\
\text { bittern }\end{array}$ & & $\begin{array}{l}\text { Satellite images analysis, } \\
\text { geospatial data processing and } \\
\text { analysis software, manual } \\
\text { visual interpretation, and } \\
\text { landscape type classification } \\
\text { system }\end{array}$ & 2015 & {$[101]$} \\
\hline China & Liuzhou & 5 & $\begin{array}{l}\text { Iron and steel making, power } \\
\text { generation, ammonia, } \\
\text { carbonate production, cement } \\
\text { and construction material } \\
\text { manufacturing companies, and } \\
\text { communities }\end{array}$ & $\begin{array}{l}\text { Waste plastics recycling, } \\
\text { scrap tire recycling, coal } \\
\text { flying ash recycling, biomass } \\
\text { utilization, and carbon } \\
\text { capture by slag carbonization }\end{array}$ & & $\begin{array}{l}\text { Questionnaires, collaboration } \\
\text { with national and local } \\
\text { governmental agencies, } \\
\text { institutes, and industrial } \\
\text { persons; onsite survey. } \\
\text { Research meetings and expert } \\
\text { reviews; urban level hybrid } \\
\text { physical input and monetary } \\
\text { output model; hybrid } \\
\text { evaluation model integrating } \\
\text { process-based life cycle } \\
\text { assessment and input-output } \\
\text { analysis; calculation of } \\
\text { increased or avoided } \\
\text { consumption, and emission in } \\
\text { the industrial symbiosis } \\
\text { process and each related sector; } \\
\text { trade-off emission; scenarios } \\
\text { design }\end{array}$ & 2017 & [37] \\
\hline China & Liuzhou & & $\begin{array}{l}\text { Iron and steel company, power } \\
\text { plant, chemical company } \\
\text { (ammonia production), } \\
\text { hydrogen manufacturing, } \\
\text { cement and construction } \\
\text { material manufacturing } \\
\text { companies, central heating for } \\
\text { the residential sector, nearby } \\
\text { plants and communities }\end{array}$ & $\begin{array}{l}\text { Metallurgical gas, waste heat, } \\
\text { waste plastics, scrap tires, } \\
\text { and coal flying ash }\end{array}$ & & $\begin{array}{l}\text { Onsite survey, analytical } \\
\text { approach integrating material } \\
\text { flows analysis (includes } \\
\text { material and energy flows } \\
\text { analysis) and emergy } \\
\text { evaluation model, avoided } \\
\text { consumption and emissions for } \\
\text { a company and } \mathrm{CO}_{2} \text { emission } \\
\text { reduction, emergy evaluation } \\
\text { index and dilution emergy }\end{array}$ & 2017 & [10] \\
\hline
\end{tabular}


Table A1. Cont.

\begin{tabular}{|c|c|c|c|c|c|c|c|c|}
\hline Country & Location/Region & $\mathrm{NE}^{1}$ & Activity & Waste/By-Products & $\begin{array}{c}\text { Infrastructure } \\
\text { Sharing/Joint } \\
\text { Provision of Services }\end{array}$ & Method & $\begin{array}{l}\text { Publication } \\
\text { Year }\end{array}$ & Refs. \\
\hline China & $\begin{array}{c}280 \text { proper cities } \\
\text { and } 357 \\
\text { county-level } \\
\text { cities }\end{array}$ & & $\begin{array}{l}\text { Electric power plant, cement } \\
\text { plants, steel plants, district } \\
\text { energy, residential and } \\
\text { commercial buildings, } \\
\text { food/beverage, and other low } \\
\text { temperature industries }\end{array}$ & $\begin{array}{l}\text { High-grade, medium-grade } \\
\text { and low-grade waste heat, fly } \\
\text { ash, and steel slag }\end{array}$ & & $\begin{array}{l}\text { What-If scenario modelling } \\
\text { approach. Cross-sectoral } \\
\text { symbiosis modelling though } \\
\text { energy cascading and material } \\
\text { exchange. Energy cascade } \\
\text { algorithms. Material-exchange } \\
\text { algorithms. Estimating } \\
\text { reductions in fuel use, } \mathrm{CO}_{2} \text { and } \\
\text { PM2.5 emissions at different } \\
\text { scales, life-cycle analysis and } \\
\text { national-economy-wide } \\
\text { economic input output-based } \\
\text { life-cycle analysis. PM2.5 } \\
\text { Pollution and health benefit } \\
\text { calculations and AERMOD } \\
\text { atmospheric dispersion } \\
\text { modeling system }\end{array}$ & 2017 & [102] \\
\hline China & Wuhan & & $\begin{array}{l}\text { Pulp and paper industry, city } \\
\text { greening, agriculture, paper } \\
\text { downstream industries } \\
\text { including printing, publishing } \\
\text { and other corresponding } \\
\text { industries, wastepaper } \\
\text { collection and disposal } \\
\text { industry, and wastewater } \\
\text { disposal industry }\end{array}$ & $\begin{array}{l}\text { Wastewater, sludge and } \\
\text { waste paper }\end{array}$ & & $\begin{array}{c}\text { Integrated life cycle } \\
\text { management assessment } \\
\text { method on the resource flows } \\
\text { of industrial ecosystem } \\
\text { including the } \\
\text { eco-environmental assessment } \\
\text { by the life cycle assessment and } \\
\text { the sustainable use assessment } \\
\text { by an indicator system }\end{array}$ & 2019 & [103] \\
\hline South Korea & & & $\begin{array}{l}\text { Iron and steel industry: } \\
\text { galvanized and aluminized } \\
\text { steel sheets producer, } \\
\text { electrolytic steel plates } \\
\text { producer, and reinforced } \\
\text { material producer for } \\
\text { automobile tires }\end{array}$ & Wastewater & & $\begin{array}{l}\text { Mathematical optimization } \\
\text { model. General algebraic } \\
\text { modeling system software. } \\
\text { Life cycle assessment and life } \\
\text { cycle costing. Estimation of } \\
\text { present value }\end{array}$ & 2010 & [104] \\
\hline
\end{tabular}


Table A1. Cont.

\begin{tabular}{|c|c|c|c|c|c|c|c|c|}
\hline Country & Location/Region & $\mathrm{NE}^{1}$ & Activity & Waste/By-Products & $\begin{array}{c}\text { Infrastructure } \\
\text { Sharing/Joint } \\
\text { Provision of Services }\end{array}$ & Method & $\begin{array}{l}\text { Publication } \\
\text { Year }\end{array}$ & Refs. \\
\hline South Korea & & & $\begin{array}{l}\text { (i) magnesium plant and } \\
\text { cement plant; (ii) magnesium } \\
\text { plant and urban area }\end{array}$ & $\begin{array}{c}\text { (i) waste slag; (ii) waste } \\
\text { energy resources (waste } \\
\text { wood, waste plastic and } \\
\text { waste tire) }\end{array}$ & & $\begin{array}{l}\text { Interview with magnesium } \\
\text { production-related specialists. } \\
\text { Quantitative estimation of } \mathrm{CO}_{2} \\
\text { emissions: } \mathrm{CO}_{2} \text { emissions from } \\
\text { fuel combustion, } \mathrm{CO}_{2} \\
\text { emissions from transportation, } \\
\mathrm{CO}_{2} \text { emissions from electricity } \\
\text { consumption and limestone } \\
\text { calcination-related } \mathrm{CO}_{2} \text { credits. } \\
\text { Uncertainty analysis }\end{array}$ & 2015 & [105] \\
\hline South Korea & Ulsan & & $\begin{array}{c}\text { Industries, factories and } \\
\text { companies and/or urban area } \\
\text { (residential and non-residential } \\
\text { buildings such as } \\
\text { hypermarkets, department } \\
\text { stores, office buildings and } \\
\text { hospitals) }\end{array}$ & $\begin{array}{c}\text { High and low-grade waste } \\
\text { heat }\end{array}$ & & $\begin{array}{l}\text { Manager interviews. Scenarios } \\
\text { analysis. Heat load analysis } \\
\text { procedure (estimation of gross } \\
\text { floor area of a building, } \\
\text { calculation of heating and } \\
\text { cooling area, connected heat } \\
\text { load, and peak heat load, and } \\
\text { estimation of heat demand } \\
\text { quantity of the target region). } \\
\mathrm{CO}_{2} \text { emission reductions from } \\
\text { the avoided fuel in the } \\
\text { company. Fuel cost reduction } \\
\text { from the avoided fuel in the } \\
\text { company }\end{array}$ & 2018 & [106] \\
\hline
\end{tabular}


Table A1. Cont.

\begin{tabular}{|c|c|c|c|c|c|c|c|c|}
\hline Country & Location/Region & $\mathrm{NE}^{1}$ & Activity & Waste/By-Products & $\begin{array}{c}\text { Infrastructure } \\
\text { Sharing/Joint } \\
\text { Provision of Services }\end{array}$ & Method & $\begin{array}{l}\text { Publication } \\
\text { Year }\end{array}$ & Refs. \\
\hline Japan & $\begin{array}{l}\text { Shinchi Town, } \\
\text { Fukushima } \\
\text { Prefecture }\end{array}$ & & $\begin{array}{l}\text { Coal-fired thermal power } \\
\text { plants and plant factories }\end{array}$ & Waste heat & & $\begin{array}{l}\text { Technical and economic } \\
\text { feasibility assessment, } \\
\text { sensitivity analysis, } \\
\text { cost-benefit assessment and } \\
\text { spatial analysis. Energy } \\
\text { generation model: influence on } \\
\text { power generation efficiency, } \\
\text { electricity loss for extracting } \\
\text { heat energy, and required cost } \\
\text { and additional } \mathrm{CO}_{2} \text { emissions } \\
\text { to compensate for power } \\
\text { generation losses. Energy } \\
\text { distribution model: heat loss } \\
\text { evaluation, pumping cost and } \\
\mathrm{CO}_{2} \text { evaluation (energy } \\
\text { consumption of the system, } \\
\text { required cost, and additional } \\
\mathrm{CO}_{2} \text { emissions in the operation } \\
\text { of a pumping system), and } \\
\text { pipeline installation cost } \\
\text { (pipeline installation cost and } \\
\text { annual rental cost with a } \\
\text { discount rate method). Energy } \\
\text { consumption model: estimated } \\
\text { energy consumption due to } \\
\text { heating in a plant factory }\end{array}$ & 2014 & [107] \\
\hline Japan & $\begin{array}{l}\text { Shinchi Town, } \\
\text { Fukushima } \\
\text { Prefecture }\end{array}$ & & $\begin{array}{l}\text { Natural gas power plant, } \\
\text { coal-based thermal power } \\
\text { plant, ceramic factory, chemical } \\
\text { factory, urban area and } \\
\text { greenhouse type plant factory }\end{array}$ & Waste heat & & $\begin{array}{l}\text { Model framework including } \\
\text { energy system design, land use } \\
\text { scenario, inventory survey and } \\
\text { geographic analysis. District } \\
\text { heating network design and } \\
\text { simulation: hydraulic analysis, } \\
\text { pipeline diameter, pressure } \\
\text { drop, necessary pumping } \\
\text { power and temperature drop. } \\
\text { Cost-benefit assessment: } \\
\text { economic costs (heat } \\
\text { distribution cost, heat transport } \\
\text { cost and management and } \\
\text { maintenance cost), benefit of } \\
\text { fuel cost reduction and } \mathrm{CO}_{2} \\
\text { reduction. Sensitivity analysis }\end{array}$ & 2018 & [13] \\
\hline
\end{tabular}


Table A1. Cont.

\begin{tabular}{|c|c|c|c|c|c|c|c|c|}
\hline Country & Location/Region & $\mathrm{NE}^{1}$ & Activity & Waste/By-Products & $\begin{array}{c}\text { Infrastructure } \\
\text { Sharing/Joint } \\
\text { Provision of Services }\end{array}$ & Method & $\begin{array}{l}\text { Publication } \\
\text { Year }\end{array}$ & Refs \\
\hline Japan & Tanegashima & & $\begin{array}{l}\text { Combined heating and power } \\
\text { plant, sugar mill, wood } \\
\text { production industry, wood } \\
\text { chip factory, wood pellet } \\
\text { factory, and forestry industry }\end{array}$ & $\begin{array}{l}\text { Waste heat, sugarcane } \\
\text { bagasse, thinning residues, } \\
\text { sawmill residues (sawdust } \\
\text { and bark), and wood } \\
\text { chipping residue (bark) }\end{array}$ & & $\begin{array}{c}\text { Interviews and discussions } \\
\text { with the on-site experts and } \\
\text { stakeholders. Scenario } \\
\text { Analysis. Energy flow analysis. } \\
\text { Greenhouse gas emissions } \\
\text { based on life cycle analysis. } \\
\text { Adjusted environmental load } \\
\text { for a scenario }\end{array}$ & 2016 & {$[108]$} \\
\hline Malaysia & & 4 & $\begin{array}{l}\text { Palm oil mill, palm oil-based } \\
\text { biorefinery, and combined heat } \\
\text { and power plant }\end{array}$ & $\begin{array}{c}\text { Empty fruit bunches, palm } \\
\text { mesocarp fiber, palm kernel } \\
\text { shell, wet short fiber and dry } \\
\text { short fiber }\end{array}$ & & $\begin{array}{l}\text { Disjunctive fuzzy optimization } \\
\text { approach. Overall degree of } \\
\text { satisfaction, annual gross profit, } \\
\text { net present value, and payback } \\
\text { period of a processing plant }\end{array}$ & 2014 & {$[109]$} \\
\hline Malaysia & & & $\begin{array}{l}\text { Various types of industries } \\
\text { within the Halal Park }\end{array}$ & & $\begin{array}{c}\text { Cooperative safety } \\
\text { management }\end{array}$ & $\begin{array}{l}\text { Open-ended interview with } \\
\text { seven industrial safety experts }\end{array}$ & 2014 & {$[110]$} \\
\hline Malaysia & Kedah & & $\begin{array}{c}\text { Fertilizer industry, rubber } \\
\text { block processor, tire producer, } \\
\text { glove manufacturer, electricity } \\
\text { co-generation, biomass } \\
\text { disintegration, cement concrete } \\
\text { industry, polymer asphalt } \\
\text { binder industry, wastewater } \\
\text { integrated facilities and } \\
\text { methane recovery unit }\end{array}$ & $\begin{array}{l}\text { Ammonia nitrogen waste, } \\
\text { rubber waste, waste water } \\
\text { from cooling system, rejected } \\
\text { glove pieces, rubber traps, } \\
\text { sludge and rubber woods, } \\
\text { rubber latex waste and waste } \\
\text { water }\end{array}$ & $\begin{array}{l}\text { Co-generation unit for } \\
\text { electricity, wastewater } \\
\text { integration unit, } \\
\text { methane development } \\
\text { unit, and central } \\
\text { storage unit }\end{array}$ & $\begin{array}{c}\text { Questionnaires. SWOT } \\
\text { analysis. Materials Flow } \\
\text { Analysis and the Input-Output } \\
\text { data based on previous Life } \\
\text { Cycle Analysis data }\end{array}$ & 2017 & {$[111]$} \\
\hline
\end{tabular}


Table A1. Cont.

\begin{tabular}{|c|c|c|c|c|c|c|c|c|}
\hline Country & Location/Region & $\mathrm{NE}^{1}$ & Activity & Waste/By-Products & $\begin{array}{c}\text { Infrastructure } \\
\text { Sharing/Joint } \\
\text { Provision of Services }\end{array}$ & Method & $\begin{array}{c}\text { Publication } \\
\text { Year }\end{array}$ & Refs. \\
\hline Turkey & Gaziantep & & $\begin{array}{l}\text { Manufacturing of textile } \\
\text { products, food products, } \\
\text { rubber and plastic products, } \\
\text { leather products, chemicals } \\
\text { and chemical products, other } \\
\text { metallic and mineral products, } \\
\text { ready-made clothing, furniture, } \\
\text { fabricated metal products, } \\
\text { paper and paper products, and } \\
\text { wood and wood products, } \\
\text { basic metal industry, } \\
\text { production and distribution of } \\
\text { electricity, gas, steam and } \\
\text { aeration systems, and } \\
\text { collection, disposal and } \\
\text { recycling of wastes }\end{array}$ & $\begin{array}{l}\text { Used carpets, PET wastes, } \\
\text { animal hides, carpet and } \\
\text { textile fibrous waste, waste } \\
\text { polyurethane and } \\
\text { ethylene-vinyl acetate, flax } \\
\text { fiber residues, polyester and } \\
\text { polyurethane based textile } \\
\text { wastes, cotton and } \\
\text { polypropylene fiber based } \\
\text { textile wastes, dairy } \\
\text { by-products, waste tyre } \\
\text { rubber, granular and fibrous } \\
\text { particles from a range of } \\
\text { plastic, rubber and textile } \\
\text { waste, wastewater treatment } \\
\text { sludge, waste foundry sand, } \\
\text { calcium carbonate wastes, } \\
\text { polyvinyl chloride wastes, } \\
\text { polyurethane foam wastes, } \\
\text { waste polyvinyl alcohol, } \\
\text { polypropylene-based plastic } \\
\text { wastes, waste paint, waste } \\
\text { glass, red mud, } \\
\text { polypropylene-based carpet } \\
\text { wastes, food processing } \\
\text { wastes, dust, waste rubbers, } \\
\text { black glass waste, acrylic } \\
\text { butyl styrene, dried sludge, } \\
\text { organic wastes (pistachio } \\
\text { processing wastes, food } \\
\text { processing wastes, etc.), } \\
\text { synthetic shoe processing } \\
\text { wastes, and waste heat }\end{array}$ & & $\begin{array}{l} \\
\text { Industrial symbiosis } \\
\text { match-making platform } \\
\text { (ESOTAß, Industrial } \\
\text { Symbiosis Opportunity } \\
\text { Screening Tool). Assigning } \\
\text { NACE and EWC codes to } \\
\text { industries and wastes. } \\
\text { Company and stakeholder } \\
\text { visits, stakeholder analysis and } \\
\text { workshops }\end{array}$ & 2017 & [112] \\
\hline Turkey & Ankara & 10 & $\begin{array}{l}\text { Machining, metals and metal } \\
\text { processing, rubber, painting } \\
\text { and plating sectors }\end{array}$ & Waste heat & & $\begin{array}{l}\text { Tool for defining data about } \\
\text { companies and process, cleaner } \\
\text { production potential and costs } \\
\text { and environmental impact } \\
\text { graph of processes. Analysis of } \\
\text { mass balance and all materials } \\
\text { for process work flows }\end{array}$ & 2018 & [113] \\
\hline
\end{tabular}


Table A1. Cont.

\begin{tabular}{|c|c|c|c|c|c|c|c|c|}
\hline Country & Location/Region & $\mathrm{NE}^{1}$ & Activity & Waste/By-Products & $\begin{array}{c}\text { Infrastructure } \\
\text { Sharing/Joint } \\
\text { Provision of Services }\end{array}$ & Method & $\begin{array}{c}\text { Publication } \\
\text { Year }\end{array}$ & Refs \\
\hline India & Puducherry & & $\begin{array}{l}\text { Sugar, paper, galvanizing, } \\
\text { granite, and gypsum } \\
\text { industries, etc. }\end{array}$ & & & $\begin{array}{c}\text { Survey method with } \\
\text { open-ended questions. } \\
\text { Analytical methods: trend } \\
\text { analysis, causal chain analysis, } \\
\text { policy analysis, training needs } \\
\text { assessment, technology needs } \\
\text { assessment and barrier } \\
\text { analysis. Content analysis. } \\
\text { SWOT analysis }\end{array}$ & 2015 & {$[114]$} \\
\hline Bangladesh & $\begin{array}{l}\text { Chittagong } \\
\text { Export } \\
\text { Processing Zone }\end{array}$ & & $\begin{array}{l}\text { Garments manufacturing } \\
\text { company, textile mills, towel } \\
\text { manufacturing company, shoe } \\
\text { accessories company, power } \\
\text { generation and distribution } \\
\text { company, crown mills, } \\
\text { incineration plant and } \\
\text { purification plant }\end{array}$ & $\begin{array}{c}\text { Waste heat, solid waste and } \\
\text { wastewater }\end{array}$ & & $\begin{array}{l}\text { On-site energy audit and } \\
\text { equipment/waste emission } \\
\text { survey. Visits to companies. } \\
\text { Input and output analysis. } \\
\text { Feasibility analysis } \\
\text { (techno-economics and } \\
\text { environmental feasibilities } \\
\text { assessment). Business model } \\
\text { development }\end{array}$ & 2015 & {$[115]$} \\
\hline Philippines & Laguna & & & & & $\begin{array}{l}\text { Questionnaires and survey } \\
\text { with ten participants from } \\
\text { different sectors of the } \\
\text { industrial park. Decision } \\
\text { Making Trial and Evaluation } \\
\text { Laboratory }\end{array}$ & 2016 & {$[116]$} \\
\hline \multicolumn{9}{|c|}{ North America } \\
\hline USA & $\begin{array}{l}\text { Johnston, } \\
\text { Chatham, Lee, } \\
\text { Orange, } \\
\text { Durham and } \\
\text { Wake Counties, } \\
\text { North Carolina }\end{array}$ & 87 & $\begin{array}{l}\text { Pharmaceutical, computer, } \\
\text { telecommunication equipment } \\
\text { manufacturers, resin } \\
\text { manufacturer, amino acids } \\
\text { manufacturing, and tool } \\
\text { manufacturing industries and } \\
\text { municipal wastewater } \\
\text { treatment plant }\end{array}$ & $\begin{array}{c}\text { Acetone, carbon, desiccant, } \\
\text { hydrochloric acid, methanol, } \\
\text { packaging materials, plastic } \\
\text { bags, sawdust, sodium } \\
\text { hydroxide, wood ash, wood } \\
\text { chips, wood fluff, absorbents, } \\
\text { blasting media, coal ash, } \\
\text { conveyor belts, copper, } \\
\text { drums, electricity, ethanol, } \\
\text { fiberglass, floppy disks, food } \\
\text { waste, foundry sand, } \\
\text { furniture fluff, glass vials, ink, } \\
\text { paint, plastic, rubber } \\
\text { blankets, steam, steel, } \\
\text { sulfuric acid, unheated water, } \\
\text { wire and wood }\end{array}$ & & $\begin{array}{l}\text { Telephone calls, in-plant } \\
\text { interviews and site visits. } \\
\text { Discussions with multiple } \\
\text { potential suppliers and users } \\
\text { and brainstorming sessions } \\
\text { with local manufacturing } \\
\text { experts. Geographic } \\
\text { information system maps with } \\
\text { an associated project database }\end{array}$ & 2001 & [60] \\
\hline
\end{tabular}


Table A1. Cont.

\begin{tabular}{|c|c|c|c|c|c|c|c|c|}
\hline Country & Location/Region & $\mathrm{NE}^{1}$ & Activity & Waste/By-Products & $\begin{array}{c}\text { Infrastructure } \\
\text { Sharing/Joint } \\
\text { Provision of Services }\end{array}$ & Method & $\begin{array}{c}\text { Publication } \\
\text { Year }\end{array}$ & Refs \\
\hline USA & Texas & & $\begin{array}{l}\text { Recycling, remanufacturing } \\
\text { and waste treatment firms }\end{array}$ & $\begin{array}{l}\text { Commercial, industrial and } \\
\text { municipal waste }\end{array}$ & & $\begin{array}{l}\text { Questionnaire survey of a } \\
\text { sample of recycling, } \\
\text { remanufacturing and waste } \\
\text { treatment firms. Modified total } \\
\text { design method }\end{array}$ & 2005 & {$[117]$} \\
\hline USA & Pittsburgh & & $\begin{array}{l}\text { Roadway construction and/or } \\
\text { repair, steel and iron industry }\end{array}$ & $\begin{array}{l}\text { Coal ash, foundry sand, and } \\
\text { slag }\end{array}$ & & $\begin{array}{l}\text { Geographic Information } \\
\text { System data; highway density } \\
\text { map, road density, and total } \\
\text { highway density; optimization } \\
\text { analysis; life cycle analysis } \\
\text { (Pavement Life Cycle } \\
\text { Assessment Tool for } \\
\text { Environmental and Economic } \\
\text { Effects program); } \\
\text { transportation cost analysis }\end{array}$ & 2008 & {$[118]$} \\
\hline Canada & Ontario & & $\begin{array}{c}\text { Solar photovoltaic } \\
\text { manufacturing plant, glass } \\
\text { manufacturing plant, glass } \\
\text { recycling facility, greenhouses, } \\
\text { and grow rooms }\end{array}$ & $\begin{array}{l}\text { Crushed cullet, waste heat, } \\
\text { and } \mathrm{CO}_{2}\end{array}$ & & Inputs and outputs analysis & 2009 & {$[119]$} \\
\hline \multicolumn{9}{|c|}{ South America } \\
\hline Brazil & & & $\begin{array}{l}\text { Agricultural activities, } \\
\text { livestock sector, and } \\
\text { alcohol-chemical industry }\end{array}$ & $\begin{array}{l}\text { Industrial by-products, } \\
\text { animal waste, straw, ashes, } \\
\text { and bagasse }\end{array}$ & & $\begin{array}{l}\text { Economic evaluation; indexes } \\
\text { of economic efficiency: } \\
\text { financing, liquid present value, } \\
\text { internal return tax, } \\
\text { contribution margin, } \\
\text { economical revenue, return } \\
\text { time, equilibrium point, and } \\
\text { accumulated cash register flow; } \\
\text { environmental and social } \\
\text { analysis; emergy method; } \\
\text { emergy indices: transformity, } \\
\text { emergy yield ratio, emergy } \\
\text { investment ratio, } \\
\text { environmental loading ratio, } \\
\text { renewability, and emergy } \\
\text { sustainability index }\end{array}$ & 2007 & {$[120]$} \\
\hline
\end{tabular}


Table A1. Cont.

\begin{tabular}{|c|c|c|c|c|c|c|c|c|}
\hline Country & Location/Region & $\mathrm{NE}^{1}$ & Activity & Waste/By-Products & $\begin{array}{c}\text { Infrastructure } \\
\text { Sharing/Joint } \\
\text { Provision of Services }\end{array}$ & Method & $\begin{array}{c}\text { Publication } \\
\text { Year }\end{array}$ & Refs. \\
\hline Brazil & $\begin{array}{l}\text { Norte } \\
\text { Fluminense } \\
\text { region }\end{array}$ & 14 & $\begin{array}{l}\text { Sugarcane farm, sugar and } \\
\text { ethanol production facilities, } \\
\text { combined heat and power } \\
\text { generation unit, biorefinery } \\
\text { consisting of the Pre-treatment } \\
\text { \& Separation, Saccharification } \\
\text { \& Co-fermentation, and } \\
\text { Concentration \& Recovery } \\
\text { units, soft drink production, } \\
\text { distilled spirits production, } \\
\text { animal feed production, } \\
\text { industrial surfactants } \\
\text { production, effluent treatment } \\
\text { facility and biogas production } \\
\text { unit, adhesives manufacturer, } \\
\text { wax production, and lube oil } \\
\text { re-refinery }\end{array}$ & $\begin{array}{l}\text { Bagasse, straw, filter cake, } \\
\text { vinasse, } \mathrm{CO}_{2} \text {, fusel oil, used } \\
\text { yeast, ash, lignin, pentose, } \\
\text { mother liquor, flue gas and } \\
\text { particulate matter, molasses, } \\
\text { bio-SA off-specification, } \\
\text { diluted salt effluent, off-gases } \\
\text { (non-recycled portion), used } \\
\text { lube oil, and other effluents }\end{array}$ & & $\begin{array}{l}\text { Interviews with stakeholders } \\
\text { and coordinators and visit to } \\
\text { the mill facilities; scenario } \\
\text { analysis, mass balance, synergy } \\
\text { matrix, and material flow } \\
\text { analysis; environmental, social, } \\
\text { and economic indicators: } \\
\text { waste emission reduction, } \\
\text { greenhouse gases savings, } \\
\text { potential job creation, and } \\
\text { feedstock remuneration } \\
\text { premium from bio-SA } \\
\text { production }\end{array}$ & 2018 & [121] \\
\hline Colombia & $\begin{array}{c}\text { Bogotá, } \\
\text { Tocancipá, Sopó, } \\
\text { Soacha, El Rosal, } \\
\text { Cajicá, Madrid, } \\
\text { Mosquera, Cota, } \\
\text { Chía, Bojacá, } \\
\text { San Francisco, } \\
\text { Funza, } \\
\text { Nemocón, } \\
\text { Saboyá }\end{array}$ & 34 & $\begin{array}{c}\text { Food processing (coffee), } \\
\text { engineering, construction, } \\
\text { waste management, beverage } \\
\text { (soft drinks), chemical } \\
\text { (specialty, agriculture } \\
\text { polyethylene films), packaging, } \\
\text { container, gas supply, food } \\
\text { (dairy, bakery and snacks), } \\
\text { glass, agriculture (flower, } \\
\text { poultry, mushroom), } \\
\text { construction supplies, } \\
\text { Styrofoam, construction and } \\
\text { home supplies, furniture, } \\
\text { flower, consulting, cosmetic, } \\
\text { wood, and restaurant }\end{array}$ & $\begin{array}{c}\text { Wood from stowage, plastic } \\
\text { waste, polystyrene foam, } \\
\text { cardboard boxes, coffee } \\
\text { residues, paper, cardboard, } \\
\text { glass, sludge/fertilizer, fruit } \\
\text { syrup, food residues, wood } \\
\text { waste, mycelium, sawdust, } \\
\text { plastic waste/geomembrane, } \\
\text { Styrofoam, and drainage } \\
\text { water }\end{array}$ & $\begin{array}{l}\text { Service sharing: sludge } \\
\text { management and } \\
\text { shared collection of } \\
\text { hazardous waste }\end{array}$ & $\begin{array}{l}\text { Workshops with companies, } \\
\text { observations, surveys to the } \\
\text { representatives with questions } \\
\text { that require evaluations and } \\
\text { open answers and } \\
\text { semi-structured interviews }\end{array}$ & 2018 & [34] \\
\hline \multicolumn{9}{|c|}{ Africa } \\
\hline Liberia & Konia & & $\begin{array}{l}\text { Piggery, rabbit farm, fishponds, } \\
\text { rice mill, anaerobic digester, } \\
\text { garden, and guest house }\end{array}$ & $\begin{array}{l}\text { Rice bran, manure, and } \\
\text { biogas digestate }\end{array}$ & Fishponds & $\begin{array}{l}\text { Interviews with a Liberia } \\
\text { nongovernmental organization } \\
\text { staff; optimization model: } \\
\text { maximum number of people } \\
\text { supported per year }\end{array}$ & 2014 & [45] \\
\hline
\end{tabular}


Table A1. Cont.

\begin{tabular}{|c|c|c|c|c|c|c|c|c|}
\hline Country & Location/Region & $\mathrm{NE}^{1}$ & Activity & Waste/By-Products & $\begin{array}{c}\text { Infrastructure } \\
\text { Sharing/Joint } \\
\text { Provision of Services }\end{array}$ & Method & $\begin{array}{c}\text { Publication } \\
\text { Year }\end{array}$ & Refs \\
\hline Mauritius & & & $\begin{array}{l}\text { Slaughterhouse, edible oil } \\
\text { refinery, scrap metal recycling } \\
\text { plant, cement manufacturer, } \\
\text { wastewater treatment plant, } \\
\text { construction products } \\
\text { manufacturer, plants operating } \\
\text { a boiler, biogas production } \\
\text { plants, composting plant, } \\
\text { animal feed manufacturer, and } \\
\text { agro-industry }\end{array}$ & $\begin{array}{l}\text { Scale, spent bleaching earth, } \\
\text { sludge, slag, dust, and } \\
\text { paunch manure }\end{array}$ & & $\begin{array}{l}\text { Desk analysis, interviews to } \\
\text { recyclers, officers at the } \\
\text { Ministry of Environment, } \\
\text { Sustainable Development, } \\
\text { Disaster, and Beach } \\
\text { Management and } \\
\text { environmental officers, and } \\
\text { framework for adopting } \\
\text { industrial symbiosis }\end{array}$ & 2017 & {$[122]$} \\
\hline Egypt & Borg El-Arab & & $\begin{array}{l}\text { Food industry, textile factories, } \\
\text { wood factory, metal factories, } \\
\text { factories for paper products, } \\
\text { construction materials factory, } \\
\text { chemicals and pharmaceuticals } \\
\text { factories, plastic factories, } \\
\text { electrical and engineering } \\
\text { products factories, brick } \\
\text { production factory, animal feed } \\
\text { production and fish farms, and } \\
\text { organic fertilizers and soil } \\
\text { amendments factories }\end{array}$ & $\begin{array}{l}\text { Suspended solid particles, } \\
\text { alkaline industrial drainage, } \\
\text { chemicals packs and barrels, } \\
\text { food residues (organic } \\
\text { wastes), gypsum, metal scrub, } \\
\text { paper sacks and chips, PVC } \\
\text { residues, sawdust, plastic } \\
\text { flashes, and wooden pallets }\end{array}$ & & $\begin{array}{c}\text { Data from internal } \\
\text { unpublished sources at the } \\
\text { Ministry of the Environment of } \\
\text { Egypt }\end{array}$ & 2018 & [61] \\
\hline \multicolumn{9}{|c|}{ Oceania } \\
\hline Australia & $\begin{array}{l}\text { New South } \\
\text { Wales }\end{array}$ & & $\begin{array}{l}\text { Serpentinite mining industry, } \\
\text { carbonation plant, power } \\
\text { generation plants, iron and } \\
\text { steel making, and cement and } \\
\text { concrete production }\end{array}$ & $\begin{array}{c}\mathrm{CO}_{2} \text {, waste ash, slag, tailings, } \\
\text { and fly ash }\end{array}$ & & Aspen modelling & 2012 & {$[123]$} \\
\hline Australia & Kwinana & 12 & $\begin{array}{l}\text { Titanium dioxide plant, fused } \\
\text { materials company, refractory } \\
\text { manufacturing industry, } \\
\text { coal-fired plant, aluminum } \\
\text { industry, chemical } \\
\text { manufacturing, construction } \\
\text { industry, water supply and } \\
\text { treatment company, cement } \\
\text { manufacturer, steel market } \\
\text { mills, refinery, and fertilizers } \\
\text { company }\end{array}$ & $\begin{array}{l}\text { Petroleum coke, phosphate } \\
\text { rock digestion off-gases, } \\
\text { nitrogen oxides waste gases, } \\
\text { and calcium chloride }\end{array}$ & & $\begin{array}{l}\text { Triple bottom-line perspective } \\
\text { and preliminary sustainability } \\
\text { assessment (social, economic, } \\
\text { and environmental) }\end{array}$ & 2013 & {$[124]$} \\
\hline
\end{tabular}




\section{References}

1. IPCC Climate Change 2014. Mitigation of Climate Change. Contribution of Working Group III to the Fifth Assessment Report of the Intergovernmental Panel on Climate Change; Cambridge University Press: Cambridge, UK, 2014.

2. Dong, F.; Wang, Y.; Su, B.; Hua, Y.; Zhang, Y. The process of peak CO2 emissions in developed economies: A perspective of industrialization and urbanization. Res. Conserv. Recycl. 2019, 141, 61-75. [CrossRef]

3. Zheng, X.; Streimikiene, D.; Balezentis, T.; Mardani, A.; Cavallaro, F.; Liao, H. A review of greenhouse gas emission profiles, dynamics, and climate change mitigation efforts across the key climate change players. J. Clean. Prod. 2019, 234, 1113-1133. [CrossRef]

4. Lowe, E.A.; Evans, L.K. Industrial ecology and industrial ecosystems. J. Clean. Prod. 1995, 3, 47-53. [CrossRef]

5. Schwarz, E.J.; Steininger, K.W. Implementing nature's lesson: The industrial recycling network enhancing regional development. J. Clean. Prod. 1997, 5, 47-56. [CrossRef]

6. Chertow, M.R. Industrial symbiosis: Literature and taxonomy. Annu. Rev. Energy. Environ. 2000, $25,313-337$. [CrossRef]

7. Chertow, M.R.; Ashton, W.S.; Espinosa, J.C. Industrial symbiosis in Puerto Rico: Environmentally related agglomeration economies. Reg. Stud. 2008, 42, 1299-1312. [CrossRef]

8. Daddi, T.; Nucci, B.; Iraldo, F. Using Life Cycle Assessment (LCA) to measure the environmental benefits of industrial symbiosis in an industrial cluster of SMEs. J. Clean. Prod. 2017, 147, 157-164. [CrossRef]

9. Dong, L.; Fujita, T.; Dai, M.; Geng, Y.; Ren, J.; Fujii, M.; Wang, Y.; Ohnishi, S. Towards preventative eco-industrial development: An industrial and urban symbiosis case in one typical industrial city in China. J. Clean. Prod. 2016, 114, 387-400. [CrossRef]

10. Sun, L.; Li, H.; Dong, L.; Fang, K.; Ren, J.; Geng, Y.; Fujii, M.; Zhang, W.; Zhang, N.; Liu, Z. Eco-benefits assessment on urban industrial symbiosis based on material flows analysis and emergy evaluation approach: A case of Liuzhou city, China. Res. Conserv. Recycl. 2017, 119, 78-88. [CrossRef]

11. Simboli, A.; Taddeo, R.; Raggi, A. The multiple dimensions of urban contexts in an industrial ecology perspective: An integrative framework. Int. J. Life Cycle Assess. 2017, 24, 1285-1296. [CrossRef]

12. Fang, K.; Dong, L.; Ren, J.; Zhang, Q.; Han, L.; Fu, H. Carbon footprints of urban transition: Tracking circular economy promotions in Guiyang, China. Ecol. Model. 2017, 365, 30-44. [CrossRef]

13. Dou, Y.; Togawa, T.; Dong, L.; Fujii, M.; Ohnishi, S.; Tanikawa, H.; Fujita, T. Innovative planning and evaluation system for district heating using waste heat considering spatial configuration: A case in Fukushima, Japan. Res. Conserv. Recycl. 2018, 128, 406-416. [CrossRef]

14. Van Berkel, R.; Fujita, T.; Hashimoto, S.; Geng, Y. Industrial and urban symbiosis in Japan: Analysis of the Eco-Town program 1997-2006. J. Environ. Manag. 2009, 90, 1544-1556. [CrossRef] [PubMed]

15. Berkel, R.V.; Fujita, T.; Hashimoto, S.; Fujii, M. Quantitative assessment of urban and industrial symbiosis in Kawasaki, Japan. Environ. Sci. Technol. 2009, 43, 1271-1281. [CrossRef] [PubMed]

16. Ness, D.A.; Xing, K. Toward a Resource-Efficient Built Environment: A Literature Review and Conceptual Model. J. Ind. Ecol. 2017, 21, 572-592. [CrossRef]

17. Zhang, X.; Chai, L. Structural features and evolutionary mechanisms of industrial symbiosis networks: Comparable analyses of two different cases. J. Clean. Prod. 2019, 213, 528-539. [CrossRef]

18. Domenech, T.; Bleischwitz, R.; Doranova, A.; Panayotopoulos, D.; Roman, L. Mapping industrial symbiosis development in Europe_ Typologies of networks, characteristics, performance and contribution to the circular economy. Res. Conserv. Recycl. 2019, 141, 76-98. [CrossRef]

19. Neves, A.; Godina, R.; Carvalho, H.; Azevedo, S.G.; Matias, J.C.O. Industrial symbiosis initiatives in United States of America and Canada: Current status and challenges. In Proceedings of the 8th International Conference on Industrial Technology and Management (ICITM), Cambridge, UK, 2-4 March 2019; pp. $247-251$.

20. De Abreu, M.C.S.; Ceglia, D. On the implementation of a circular economy: The role of institutional capacity-building through industrial symbiosis. Res. Conserv. Recycl. 2018, 138, 99-109. [CrossRef]

21. Pakarinen, S.; Mattila, T.; Melanen, M.; Nissinen, A.; Sokka, L. Sustainability and industrial symbiosis-The evolution of a Finnish forest industry complex. Res. Conserv. Recycl. 2010, 54, 1393-1404. [CrossRef]

22. Sokka, L.; Pakarinen, S.; Melanen, M. Industrial symbiosis contributing to more sustainable energy use-An example from the forest industry in Kymenlaakso, Finland. J. Clean. Prod. 2011, 19, 285-293. [CrossRef]

23. Mathews, J.A.; Tan, H. Progress toward a circular economy in China. J. Ind. Ecol. 2011, 15, 435-457. [CrossRef] 
24. Liu, Z.; Adams, M.; Cote, R.P.; Chen, Q.; Wu, R.; Wen, Z.; Liu, W.; Dong, L. How does circular economy respond to greenhouse gas emissions reduction: An analysis of Chinese plastic recycling industries. Renew. Sustain. Energy Rev. 2018, 91, 1162-1169. [CrossRef]

25. Shi, H.; Chertow, M.; Song, Y. Developing country experience with eco-industrial parks: A case study of the Tianjin economic-technological development area in China. J. Clean. Prod. 2010, 18, 191-199. [CrossRef]

26. Ashton, W.S. The structure, function, and evolution of a regional industrial Ecosystem. J. Ind. Ecol. 2009, 13, 228-246. [CrossRef]

27. Ashton, W.S. Managing performance expectations of industrial symbiosis. Bus. Strategy Environ. 2011, 20, 297-309. [CrossRef]

28. MacLachlan, I. Kwinana Industrial Area: Agglomeration economies and industrial symbiosis on Western Australia's Cockburn Sound. Aust. Geogr. 2013, 44, 383-400. [CrossRef]

29. Golev, A.; Corder, G.D.; Giurco, D.P. Industrial symbiosis in Gladstone: A decade of progress and future development. J. Clean. Prod. 2014, 84, 421-429. [CrossRef]

30. Freitas, L.; Magrini, A. Waste Management in Industrial Construction: Investigating Contributions from Industrial Ecology. Sustainability 2017, 9, 1251. [CrossRef]

31. Cerceau, J.; Mat, N.; Junqua, G.; Lin, L.; Laforest, V.; Gonzalez, C. Implementing industrial ecology in port cities: International overview of case studies and cross-case analysis. J. Clean. Prod. 2014, 74, 1-16. [CrossRef]

32. Mortensen, L.; Kørnøv, L. Critical factors for industrial symbiosis emergence process. J. Clean. Prod. 2019, 212, 56-69. [CrossRef]

33. Walls, J.L.; Paquin, R.L. Organizational perspectives of industrial symbiosis: A review and synthesis. Organ. Environ. 2015, 28, 32-53. [CrossRef]

34. Park, J.; Duque-Hernández, J.; Díaz-Posada, N. Facilitating business collaborations for industrial symbiosis: The pilot experience of the sustainable industrial network program in Colombia. Sustainability 2018, 10, 3637. [CrossRef]

35. Marchi, B.; Zanoni, S.; Pasetti, M. Industrial symbiosis for greener horticulture practices: $\mathrm{The}_{2} \mathrm{CO}_{2}$ enrichment from energy intensive industrial processes. Procedia CIRP 2018, 69, 562-567. [CrossRef]

36. Leurent, M.; Da Costa, P.; Sylvestre, S.; Berthélemy, M. Feasibility assessment of the use of steam sourced from nuclear plants for French factories considering spatial configuration. J. Clean. Prod. 2018, 189, 529-538. [CrossRef]

37. Dong, L.; Liang, H.; Zhang, L.; Liu, Z.; Gao, Z.; Hu, M. Highlighting regional eco-industrial development: Life cycle benefits of an urban industrial symbiosis and implications in China. Ecol. Model. 2017, 361, 164-176. [CrossRef]

38. Marconi, M.; Gregori, F.; Germani, M.; Papetti, A.; Favi, C. An approach to favor industrial symbiosis: The case of waste electrical and electronic equipment. Procedia Manuf. 2018, 21, 502-509. [CrossRef]

39. Li, H.; Dong, L.; Ren, J. Industrial symbiosis as a countermeasure for resource dependent city: A case study of Guiyang, China. J. Clean. Prod. 2015, 107, 252-266. [CrossRef]

40. Liu, C.; Côté, R.P.; Zhang, K. Implementing a three-level approach in industrial symbiosis. J. Clean. Prod. 2015, 87, 318-327. [CrossRef]

41. Patricio, J.; Axelsson, L.; Blomé, S.; Rosado, L. Enabling industrial symbiosis collaborations between SMEs from a regional perspective. J. Clean. Prod. 2018, 202, 1120-1130. [CrossRef]

42. Notarnicola, B.; Tassielli, G.; Renzulli, P.A. Industrial symbiosis in the Taranto industrial district: Current level, constraints and potential new synergies. J. Clean. Prod. 2016, 122, 133-143. [CrossRef]

43. Illsley, B.; Jackson, T.; Lynch, B. Addressing Scottish rural fuel poverty through a regional industrial symbiosis strategy for the Scottish forest industries sector. Geoforum 2007, 38, 21-32. [CrossRef]

44. Albu, A. Industrial symbiosis: An innovative tool for promoting green growth. In Sustainable Economic Development; Leal Filho, W., Pociovalisteanu, D.-M., Al-Amin, A.Q., Eds.; Springer International Publishing: Cham, Switzerland, 2017; pp. 1-29. ISBN 978-3-319-45079-7.

45. Alfaro, J.; Miller, S. Applying industrial symbiosis to smallholder farms: Modeling a case study in Liberia, West Africa. J. Ind. Ecol. 2014, 18, 145-154. [CrossRef]

46. Golev, A.; Corder, G.D.; Giurco, D.P. Barriers to industrial symbiosis: Insights from the use of a maturity grid. J. Ind. Ecol. 2015, 19, 141-153. [CrossRef]

47. Fichtner, W.; Tietze-Stöckinger, I.; Frank, M.; Rentz, O. Barriers of interorganisational environmental management: Two case studies on industrial symbiosis. Prog. Ind. Ecol. Int. J. 2005, 2, 73-88. [CrossRef] 
48. Kokoulina, L.; Ermolaeva, L.; Patala, S.; Ritala, P. Championing processes and the emergence of industrial symbiosis. Reg. Stud. 2019, 53, 528-539. [CrossRef]

49. Mirata, M. Experiences from early stages of a national industrial symbiosis programme in the UK: Determinants and coordination challenges. J. Clean. Prod. 2004, 12, 967-983. [CrossRef]

50. Chertow, M.R. "Uncovering" industrial symbiosis. J. Ind. Ecol. 2007, 11, 11-30. [CrossRef]

51. Yu, F.; Han, F.; Cui, Z. Evolution of industrial symbiosis in an eco-industrial park in China. J. Clean. Prod. 2015, 87, 339-347. [CrossRef]

52. Fraccascia, L.; Giannoccaro, I.; Albino, V. Efficacy of landfill tax and subsidy policies for the emergence of industrial symbiosis networks: An agent-based simulation study. Sustainability 2017, 9, 521. [CrossRef]

53. Iacondini, A.; Mencherini, U.; Passarini, F.; Vassura, I.; Fanelli, A.; Cibotti, P. Feasibility of industrial symbiosis in italy as an opportunity for economic development: Critical success factor analysis, impact and constrains of the specific Italian regulations. Waste Biomass Valoriz. 2015, 6, 865-874. [CrossRef]

54. Herczeg, G.; Akkerman, R.; Hauschild, M.Z. Supply chain collaboration in industrial symbiosis networks. J. Clean. Prod. 2018, 171, 1058-1067. [CrossRef]

55. Zhu, J.; Ruth, M. The development of regional collaboration for resource efficiency: A network perspective on industrial symbiosis. Comput. Environ. Urban Syst. 2014, 44, 37-46. [CrossRef]

56. Chertow, M.; Park, J. Chapter 14-Reusing nonhazardous industrial waste across business clusters. In Waste; Letcher, T.M., Vallero, D.A., Eds.; Academic Press: Boston, MA, USA, 2011; pp. 197-206. ISBN 978-0-12-381475-3.

57. Chertow, M.; Ehrenfeld, J. Organizing self-organizing systems. J. Ind. Ecol. 2012, 16, 13-27. [CrossRef]

58. Neves, A.; Godina, R.; Azevedo, S.G.; Matias, J.C.O. A comprehensive review of industrial symbiosis. J. Clean. Prod. 2019, in press. [CrossRef]

59. Chertow, M.; Park, J. Scholarship and practice in industrial symbiosis: 1989-2014. In Taking Stock of Industrial Ecology; Clift, R., Druckman, A., Eds.; Springer International Publishing: Cham, Switzerland, 2016; pp. 87-116. ISBN 978-3-319-20571-7.

60. Kincaid, J.; Overcash, M. Industrial Ecosystem Development at the Metropolitan Level. J. Ind. Ecol. 2001, 5, 117-126. [CrossRef]

61. ElMassah, S. Industrial symbiosis within eco-industrial parks: Sustainable development for Borg El-Arab in Egypt. Bus. Strategy Environ. 2018, 27, 884-892. [CrossRef]

62. D'Amico, F.; Buleandra, M.M.; Velardi, M.; Tanase, I. Industrial ecology as "best available technique": A case study of the Italian Industrial District of Murano. Prog. Ind. Ecol. Int. J. 2007, 4, 268-287. [CrossRef]

63. Ardente, F.; Cellura, M.; Lo Brano, V.; Mistretta, M. Life cycle assessment-driven selection of industrial ecology strategies. Integr. Environ. Assess. Manag. 2010, 6, 52-60.

64. Simboli, A.; Taddeo, R.; Morgante, A. Analysing the development of Industrial Symbiosis in a motorcycle local industrial network: The role of contextual factors. J. Clean. Prod. 2014, 66, 372-383. [CrossRef]

65. Simboli, A.; Taddeo, R.; Morgante, A. The potential of Industrial Ecology in agri-food clusters (AFCs): A case study based on valorisation of auxiliary materials. Ecol. Econ. 2015, 111, 65-75. [CrossRef]

66. Luciano, A.; Barberio, G.; Mancuso, E.; Sbaffoni, S.; La Monica, M.; Scagliarino, C.; Cutaia, L. Potential improvement of the methodology for industrial symbiosis implementation at regional scale. Waste Biomass Valoriz. 2016, 7, 1007-1015. [CrossRef]

67. Marchi, B.; Zanoni, S.; Zavanella, L.E. Symbiosis between industrial systems, utilities and public service facilities for boosting energy and resource efficiency. Energy Procedia 2017, 128, 544-550. [CrossRef]

68. Wolf, A.; Eklund, M.; Soderstrom, M. Towards cooperation in industrial symbiosis: Considering the importance of the human dimension. Prog. Ind. Ecol. Int. J. 2005, 2, 185-199. [CrossRef]

69. Karlsson, M.; Wolf, A. Using an optimization model to evaluate the economic benefits of industrial symbiosis in the forest industry. J. Clean. Prod. 2008, 16, 1536-1544. [CrossRef]

70. Wolf, A.; Karlsson, M. Evaluating the environmental benefits of industrial symbiosis: Discussion and demonstration of a new approach. Prog. Ind. Ecol. Int. J. 2008, 5, 502-517. [CrossRef]

71. Johansson, M.T.; Söderström, M. Options for the Swedish steel industry—Energy efficiency measures and fuel conversion. Energy 2011, 36, 191-198. [CrossRef]

72. Aid, G.; Brandt, N.; Lysenkova, M.; Smedberg, N. Looplocal-A heuristic visualization tool to support the strategic facilitation of industrial symbiosis. J. Clean. Prod. 2015, 98, 328-335. [CrossRef] 
73. Patricio, J.; Angelis-Dimakis, A.; Castillo-Castillo, A.; Kalmykova, Y.; Rosado, L. Method to identify opportunities for CCU at regional level-Matching sources and receivers. J. CO2 Util. 2017, 22, 330-345. [CrossRef]

74. Wassenaar, T.; Paillat, J.-M.; Guerrin, F.; Lecomte, P.; Médoc, J.-M.; Parrot, L.; Queste, J.; Salgado, P.; Tillard, E.; Vayssières, J. Inter-supply chain recycling of residues. In Sustainable Development and Tropical Agri-Chains; Biénabe, E., Rival, A., Loeillet, D., Eds.; Springer: Dordrecht, The Netherlands, 2017; pp. 201-217, ISBN 978-94-024-1016-7.

75. Afshari, H.; Farel, R.; Peng, Q. Challenges of value creation in Eco-Industrial Parks (EIPs): A stakeholder perspective for optimizing energy exchanges. Res. Conserv. Recycl. 2018, 139, 315-325. [CrossRef]

76. Ribeiro, P.; Fonseca, F.; Neiva, C.; Bardi, T.; Lourenço, J.M. An integrated approach towards transforming an industrial park into an eco-industrial park: The case of Salaise-Sablons. J. Environ. Plan. Manag. 2018, 61, 195-213. [CrossRef]

77. Watkins, G.; Makela, M.; Dahl, O. Innovative use potential of industrial residues from the steel, paper and pulp industries-A preliminary study. Prog. Ind. Ecol. Int. J. 2010, 7, 185-204. [CrossRef]

78. Tsvetkova, A.; Hellström, M.; Gustafsson, M.; Sjöblom, J. Replication of industrial ecosystems: The case of a sustainable biogas-for-traffic solution. J. Clean. Prod. 2015, 98, 123-132. [CrossRef]

79. Nasiri, M.; Rantala, T.; Saunila, M.; Ukko, J.; Rantanen, H. Transition towards sustainable solutions: Product, service, technology, and business model. Sustainability 2018, 10, 358. [CrossRef]

80. Cecelja, F.; Raafat, T.; Trokanas, N.; Innes, S.; Smith, M.; Yang, A.; Zorgios, Y.; Korkofygas, A.; Kokossis, A. e-Symbiosis: Technology-enabled support for industrial symbiosis targeting small and medium enterprises and innovation. J. Clean. Prod. 2015, 98, 336-352. [CrossRef]

81. Ntasiou, M.; Andreou, E. The standard of industrial symbiosis. Environmental criteria and methodology on the establishment and operation of industrial and business parks. Procedia Environ. Sci. 2017, 38, 744-751. [CrossRef]

82. Mouzakitis, Y.; Aminalragia-Giamini, R.; Adamides, E.D. From the treatment of Olive Mills wastewater to its valorisation: Towards a bio-economic industrial symbiosis. In Proceedings of the Sustainable Design and Manufacturing 2017, Bologna, Italy, 26-28 April 2017; Campana, G., Howlett, R.J., Setchi, R., Cimatti, B., Eds.; Springer International Publishing: Berlin, Germany, 2017; pp. 267-276.

83. Sterr, T.; Ott, T. The industrial region as a promising unit for eco-industrial development-Reflections, practical experience and establishment of innovative instruments to support industrial ecology. J. Clean. Prod. 2004, 12, 947-965. [CrossRef]

84. Hildebrandt, J.; O'Keeffe, S.; Bezama, A.; Thrän, D. Revealing the environmental advantages of industrial symbiosis in wood-based bioeconomy networks: An assessment from a life cycle perspective. J. Ind. Ecol. 2018. [CrossRef]

85. Illsley, B.; Jackson, T.; Lynch, B. Promoting environmental justice through industrial symbiosis: Developing pelletised wood fuel to tackle Scottish rural fuel poverty. Prog. Ind. Ecol. Int. J. 2007, 4, 219-232. [CrossRef]

86. Ruiz Puente, M.C.; Arozamena, E.R.; Evans, S. Industrial symbiosis opportunities for small and medium sized enterprises: Preliminary study in the Besaya region (Cantabria, Northern Spain). J. Clean. Prod. 2015, 87, 357-374. [CrossRef]

87. Álvarez, R.; Ruiz-Puente, C. Development of the Tool SymbioSyS to support the transition towards a circular economy based on industrial symbiosis strategies. Waste Biomass Valoriz. 2017, 8, 1521-1530. [CrossRef]

88. Kliopova, I.; Baranauskaitè-Fedorova, I.; Malinauskienè, M.; Staniškis, J.K. Possibilities of increasing resource efficiency in nitrogen fertilizer production. Clean Technol. Environ. Policy 2016, 18, 901-914. [CrossRef]

89. Malinauskienė, M.; Kliopova, I.; Hugi, C.; Staniškis, J.K. Geostrategic supply risk and economic importance as drivers for implementation of industrial ecology measures in a nitrogen fertilizer production company. J. Ind. Ecol. 2018, 22, 422-433. [CrossRef]

90. Jackson, T. The role of industrial symbiosis in promoting bio-fuel feedstock uses for UK food and fibre production. Prog. Ind. Ecol. Int. J. 2008, 5, 349-360. [CrossRef]

91. Zhang, X.; Strømman, A.H.; Solli, C.; Hertwich, E.G. Model-centered approach to early planning and design of an eco-industrial park around an oil refinery. Environ. Sci. Technol. 2008, 42, 4958-4963. [CrossRef]

92. Jensen, P.D.; Basson, L.; Hellawell, E.E.; Leach, M. 'Habitat' suitability index mapping for industrial symbiosis planning. J. Ind. Ecol. 2012, 16, 38-50. [CrossRef] 
93. Salmi, O.; Hukkinen, J.; Heino, J.; Pajunen, N.; Wierink, M. Governing the Interplay between industrial ecosystems and environmental regulation: Heavy industries in the Gulf of Bothnia in Finland and Sweden. J. Ind. Ecol. 2012, 16, 119-128. [CrossRef]

94. Beloborodko, A.; Rosa, M. The use of performance indicators for analysis of resource efficiency measures. Energy Procedia 2015, 72, 337-344. [CrossRef]

95. Abate, S.; Lanzafame, P.; Perathoner, S.; Centi, G. New sustainable model of biorefineries: Biofactories and challenges of integrating bio- and solar refineries. ChemSusChem 2015, 8, 2854-2866. [CrossRef]

96. Yuan, W.; Zhao, X.; Liu, W. Study on the circulation development pattern of Handan's heavy chemical industry based on industrial symbiosis. In Proceedings of the International Conference on E-Learning, E-Business, Enterprise Information Systems, and E-Government, Las Vegas, NV, USA, 13-16 July 2009; pp. 196-199.

97. Hara, K.; Yabar, H.; Uwasu, M.; Zhang, H. Energy intensity trends and scenarios for China's industrial sectors: A regional case study. Sustain. Sci. 2011, 6, 123-134. [CrossRef]

98. Liu, Q.; Jiang, P.; Zhao, J.; Zhang, B.; Bian, H.; Qian, G. Life cycle assessment of an industrial symbiosis based on energy recovery from dried sludge and used oil. J. Clean. Prod. 2011, 19, 1700-1708. [CrossRef]

99. Yang, S.; Yu, C.; Li, X.; Yu, Q. A case study of industrial symbiosis: YunFu Boli Co., Ltd. in China. In Proceedings of the Asia-Pacific Power and Energy Engineering Conference, Wuhan, China, 25-28 March 2011; pp. 1-3.

100. Zhou, X.; Zhang, H. Research on industrial symbiosis mode logistics industrial cluster in Shenyang Economic Zone. In Proceedings of the International Conference on Information Management, Innovation Management and Industrial Engineering, Sanya, China, 20-21 October 2012; pp. 489-492.

101. Wang, H.; Xu, X.; Zhu, G. Landscape changes and a salt production sustainable approach in the state of salt pan area decreasing on the Coast of Tianjin, China. Sustainability 2015, 7, 10078-10097. [CrossRef]

102. Ramaswami, A.; Tong, K.; Fang, A.; Lal, R.M.; Nagpure, A.S.; Li, Y.; Yu, H.; Jiang, D.; Russell, A.G.; Shi, L.; et al. Urban cross-sector actions for carbon mitigation with local health co-benefits in China. Nat. Clim. Chang. 2017, 7, 736-742. [CrossRef]

103. Shi, X.; Li, X. A symbiosis-based life cycle management approach for sustainable resource flows of industrial ecosystem. J. Clean. Prod. 2019, 226, 324-335. [CrossRef]

104. Lim, S.-R.; Park, J.M. Interfactory and intrafactory water network system to remodel a conventional industrial park to a green eco-industrial park. Ind. Eng. Chem. Res. 2010, 49, 1351-1358. [CrossRef]

105. Kwon, G.-R.; Woo, S.H.; Lim, S.-R. Industrial ecology-based strategies to reduce the embodied CO2 of magnesium metal. Resour. Conserv. Recycl. 2015, 104, 206-212. [CrossRef]

106. Kim, H.-W.; Dong, L.; Choi, A.E.S.; Fujii, M.; Fujita, T.; Park, H.-S. Co-benefit potential of industrial and urban symbiosis using waste heat from industrial park in Ulsan, Korea. Resour. Conserv. Recycl. 2018, 135, $225-234$. [CrossRef]

107. Togawa, T.; Fujita, T.; Dong, L.; Fujii, M.; Ooba, M. Feasibility assessment of the use of power plant-sourced waste heat for plant factory heating considering spatial configuration. J. Clean. Prod. 2014, 81, 60-69. [CrossRef]

108. Kikuchi, Y.; Kanematsu, Y.; Ugo, M.; Hamada, Y.; Okubo, T. Industrial symbiosis centered on a regional cogeneration power plant utilizing available local resources: A case study of Tanegashima. J. Ind. Ecol. 2016, 20, 276-288. [CrossRef]

109. Ng, R.T.L.; Ng, D.K.S.; Tan, R.R.; El-Halwagi, M.M. Disjunctive fuzzy optimisation for planning and synthesis of bioenergy-based industrial symbiosis system. J. Environ. Chem. Eng. 2014, 2, 652-664. [CrossRef]

110. Ramli, A.; Mokhtar, M.; Aziz, B.A.; Ngah, N.A. The cooperative approach in managing safety issues for Halal industrial parks in Malaysia: Embracing opportunity. Prog. Ind. Ecol. Int. J. 2014, 8, 295-318. [CrossRef]

111. Sharib, S.; Halog, A. Enhancing value chains by applying industrial symbiosis concept to the Rubber City in Kedah, Malaysia. J. Clean. Prod. 2017, 141, 1095-1108. [CrossRef]

112. Uludag-Demirer, S.; Demirer, G.N. Determination of regional industrial symbiosis opportunities by using relationship mimicking with ESOTA®. Prog. Ind. Ecol. Int. J. 2017, 11, 343-360. [CrossRef]

113. Çolak, L.; Akcengiz, P.Y. Transition from conventional to sustainable production: A case study in OSTIM organized industrial zone. In Proceedings of the International Sustainable Buildings Symposium, Dubai, UAE, 15-17 March 2017; Firat, S., Kinuthia, J., Abu-Tair, A., Eds.; Springer International Publishing: Cham, Switzerland, 2018; Volume 6, pp. 525-533, ISBN 978-3-319-63708-2. 
114. Patnaik, R.; Poyyamoli, G. Developing an eco-industrial park in Puducherry region, India-A SWOT analysis. J. Environ. Plan. Manag. 2015, 58, 976-996. [CrossRef]

115. Behera, S.K.; Chae, S.-H.; Yeo, H.-K.; Park, H.-S. Enhancement of eco-production capacity in Chittagong Export Processing Zone (CEPZ), Bangladesh, employing Korean EIP transition strategy. In Cities and Sustainability: Issues and Strategic Pathways; Dev, S.M., Yedla, S., Eds.; Springer India: New Delhi, India, 2015; pp. 63-80. ISBN 978-81-322-2310-8.

116. Bacudio, L.R.; Benjamin, M.F.D.; Eusebio, R.C.P.; Holaysan, S.A.K.; Promentilla, M.A.B.; Yu, K.D.S.; Aviso, K.B. Analyzing barriers to implementing industrial symbiosis networks using DEMATEL. Sustain. Prod. Consum. 2016, 7, 57-65. [CrossRef]

117. Lyons, D. Integrating waste, manufacturing and industrial symbiosis: An analysis of recycling, remanufacturing and waste treatment firms in Texas. Local Environ. 2005, 10, 71-86. [CrossRef]

118. Carpenter, A.C.; Gardner, K.H. Use of industrial by-products in urban transportation infrastructure: Argument for increased industrial symbiosis. In Proceedings of the IEEE International Symposium on Electronics and the Environment, San Francisco, CA, USA, 19-22 May 2008; pp. 1-7.

119. Nosrat, A.H.; Jeswiet, J.; Pearce, J.M. Cleaner production via industrial symbiosis in glass and largescale solar photovoltaic manufacturing. In Proceedings of the Toronto International Conference Science and Technology for Humanity (TIC-STH), Toronto, ON, Canada, 26-27 September 2009; pp. 967-970.

120. Ometto, A.R.; Ramos, P.A.R.; Lombardi, G. The benefits of a Brazilian agro-industrial symbiosis system and the strategies to make it happen. J. Clean. Prod. 2007, 15, 1253-1258. [CrossRef]

121. Santos, V.E.N.; Magrini, A. Biorefining and industrial symbiosis: A proposal for regional development in Brazil. J. Clean. Prod. 2018, 177, 19-33. [CrossRef]

122. Mauthoor, S. Uncovering industrial symbiosis potentials in a small island developing state: The case study of Mauritius. J. Clean. Prod. 2017, 147, 506-513. [CrossRef]

123. Brent, G.F.; Allen, D.J.; Eichler, B.R.; Petrie, J.G.; Mann, J.P.; Haynes, B.S. Mineral carbonation as the core of an industrial symbiosis for energy-intensive minerals conversion. J. Ind. Ecol. 2012, 16, 94-104. [CrossRef]

124. Mohammed, F.A.; Biswas, W.K.; Yao, H.M.; Tadé, M.O. Assessment of industrial by-product synergies from process engineering and sustainability principles. Prog. Ind. Ecol. Int. J. 2013, 8, 156-165. [CrossRef]

125. Ghisellini, P.; Cialani, C.; Ulgiati, S. A review on circular economy: The expected transition to a balanced interplay of environmental and economic systems. J. Clean. Prod. 2016, 114, 11-32. [CrossRef]

126. Kirchherr, J.; Reike, D.; Hekkert, M. Conceptualizing the circular economy: An analysis of 114 definitions. Resour. Conserv. Recycl. 2017, 127, 221-232. [CrossRef]

127. Roberts, B.H. The application of industrial ecology principles and planning guidelines for the development of eco-industrial parks: An Australian case study. J. Clean. Prod. 2004, 12, 997-1010. [CrossRef]

128. Merli, R.; Preziosi, M.; Acampora, A. How do scholars approach the circular economy? A systematic literature review. J. Clean. Prod. 2018, 178, 703-722. [CrossRef]

129. Jensen, P.D. The role of geospatial industrial diversity in the facilitation of regional industrial symbiosis. Resour. Conserv. Recycl. 2016, 107, 92-103. [CrossRef]

130. Guo, B.; Geng, Y.; Sterr, T.; Dong, L.; Liu, Y. Evaluation of promoting industrial symbiosis in a chemical industrial park: A case of Midong. J. Clean. Prod. 2016, 135, 995-1008. [CrossRef]

131. Aid, G.; Eklund, M.; Anderberg, S.; Baas, L. Expanding roles for the Swedish waste management sector in inter-organizational resource management. Resour. Conserv. Recycl. 2017, 124, 85-97. [CrossRef]

132. Deutz, P.; Baxter, H.; Gibbs, D.; Mayes, W.M.; Gomes, H.I. Resource recovery and remediation of highly alkaline residues: A political-industrial ecology approach to building a circular economy. Geoforum 2017, 85, 336-344. [CrossRef]

133. Husgafvel, R.; Nordlund, H.; Heino, J.; Mäkelä, M.; Watkins, G.; Dahl, O.; Paavola, I.-L. Use of symbiosis products from integrated pulp and paper and carbon steel mills: Legal status and environmental burdens. J. Ind. Ecol. 2016, 20, 1187-1198. [CrossRef]

134. Stegemann, J.A. The potential role of energy-from-waste air pollution control residues in the industrial ecology of cement. J. Sustain. Cem. Based Mater. 2014, 3, 111-127. [CrossRef]

135. Husgafvel, R.; Karjalainen, E.; Linkosalmi, L.; Dahl, O. Recycling industrial residue streams into a potential new symbiosis product-The case of soil amelioration granules. J. Clean. Prod. 2016, 135, 90-96. [CrossRef] 
136. Manara, P.; Zabaniotou, A. Co-valorization of crude glycerol waste streams with conventional and/or renewable fuels for power generation and industrial symbiosis perspectives. Waste and Biomass Valoriz. 2016, 7, 135-150. [CrossRef]

137. Charles, R.G.; Douglas, P.; Baker, J.A.; Carnie, M.J.; Douglas, J.O.; Penney, D.J.; Watson, T.M. Platinized counter-electrodes for dye-sensitised solar cells from waste thermocouples: A case study for resource efficiency, industrial symbiosis and circular economy. J. Clean. Prod. 2018, 202, 1167-1178. [CrossRef]

138. Cusenza, M.A.; Guarino, F.; Longo, S.; Mistretta, M.; Cellura, M. Reuse of electric vehicle batteries in buildings: An integrated load match analysis and life cycle assessment approach. Energy Build. 2019, 186, 339-354. [CrossRef]

139. Mohammed, F.; Biswas, W.K.; Yao, H.; Tadé, M. Identification of an environmentally friendly symbiotic process for the reuse of industrial byproduct-An LCA perspective. J. Clean. Prod. 2016, 112, 3376-3387. [CrossRef]

140. Mohammed, F.; Biswas, W.K.; Yao, H.; Tadé, M. Sustainability assessment of symbiotic processes for the reuse of phosphogypsum. J. Clean. Prod. 2018, 188, 497-507. [CrossRef]

141. Mathur, N.; Deng, S.; Singh, S.; Yih, Y.; Sutherland, J.W. Evaluating the environmental benefits of implementing Industrial Symbiosis to used electric vehicle batteries. Procedia CIRP 2019, 80, 661-666. [CrossRef]

142. Ali, A.K.; Wang, Y.; Alvarado, J.L. Facilitating industrial symbiosis to achieve circular economy using value-added by design: A case study in transforming the automobile industry sheet metal waste-flow into Voronoi facade systems. J. Clean. Prod. 2019, 234, 1033-1044. [CrossRef]

143. De Freitas, S.M.A.C.; Sousa, L.N.; Diniz, P.; Martins, M.E.; Assis, P.S. Steel slag and iron ore tailings to produce solid brick. Clean Technol. Environ. Policy 2018, 20, 1087-1095. [CrossRef]

144. Marwede, M.; Schischke, K.; Arranz, P.; Hickey, S.; Fitzpatrick, C.; Ospina, J.; Yang, M.; Nissen, N.F.; Lang, K. Methodology to identify design for recycling measures for high-tech sectors. In Proceedings of the 2012 Electronics Goes Green 2012+, Berlin, Germany, 9-12 September 2012; pp. 1-6.

145. Bustos, G.; Calvar, S.; Vecino, X.; Cruz, J.M.; Moldes, A.B. Industrial symbiosis between the winery and environmental industry through the utilization of grape Marc for water desalination containing copper(II). Water Air Soil Pollut. 2018, 229, 36. [CrossRef]

146. Neves, A.; Azevedo, S.G.; Matias, J.C.O. Environmental, economic, and social impact of industrial symbiosis: Methods and indicators review. In Proceedings of the Industrial Engineering and Operations Management II, Lisbon, Portugal, 18-20 July 2018; Reis, J., Pinelas, S., Melão, N., Eds.; Springer International Publishing: Berlin, Germany, 2019; pp. 157-165.

147. European Commission. Roadmap to a Resource Efficient Europe; COM (2011) 571 Final; European Commission: Brussels, Belgium, 2011.

148. European Commission. Closing the Loop - An EU Action Plan for the Circular Economy; COM(2015) 614 Final; European Commission: Brussels, Belgium, 2015.

149. European Parliament, Council of the European Union. Directive 2018/851 of the European Parliament and of the Council of 30 May 2018 Amending Directive 2008/98/EC on Waste; European Parliament, Council of the European Union: Brussels, Belgium, 2018; pp. 109-140.

150. Daddi, T.; Tessitore, S.; Testa, F. Industrial ecology and eco-industrial development: Case studies from Italy. Prog. Ind. Ecol. Int. J. 2015, 9, 217-233. [CrossRef]

151. Wolf, A.; Petersson, K. Industrial symbiosis in the Swedish forest industry. Prog. Ind. Ecol. Int. J. 2007, 4, 348-362. [CrossRef]

152. Taddeo, R.; Simboli, A.; Morgante, A.; Erkman, S. The development of industrial symbiosis in existing contexts. experiences from three Italian clusters. Ecol. Econ. 2017, 139, 55-67. [CrossRef]

153. Liu, X.; Bae, J. Urbanization and industrialization impact of $\mathrm{CO} 2$ emissions in China. J. Clean. Prod. 2018, 172, 178-186. [CrossRef]

154. Guan, Y.; Huang, G.; Liu, L.; Zhai, M.; Zheng, B. Dynamic analysis of industrial solid waste metabolism at aggregated and disaggregated levels. J. Clean. Prod. 2019, 221, 817-827. [CrossRef]

155. Liu, Z.; Adams, M.; Cote, R.P.; Geng, Y.; Chen, Q.; Liu, W.; Sun, L.; Yu, X. Comprehensive development of industrial symbiosis for the response of greenhouse gases emission mitigation: Challenges and opportunities in China. Energy Policy 2017, 102, 88-95. [CrossRef] 
156. Dong, L.; Gu, F.; Fujita, T.; Hayashi, Y.; Gao, J. Uncovering opportunity of low-carbon city promotion with industrial system innovation: Case study on industrial symbiosis projects in China. Energy Policy 2014, 65, 388-397. [CrossRef]

157. Guan, Y.; Huang, G.; Liu, L.; Huang, C.Z.; Zhai, M. Ecological network analysis for an industrial solid waste metabolism system. Environ. Pollut. 2019, 244, 279-287. [CrossRef]

158. Liu, C.; Côté, R. A framework for integrating ecosystem services into China's circular economy: The case of eco-industrial parks. Sustainability 2017, 9, 1510. [CrossRef]

159. Huang, B.; Yong, G.; Zhao, J.; Domenech, T.; Liu, Z.; Chiu, S.F.; McDowall, W.; Bleischwitz, R.; Liu, J.; Yao, Y. Review of the development of China's eco-industrial park standard system. Resour. Conserv. Recycl. 2019, 140, 137-144. [CrossRef]

160. Zhu, X.; Zeng, A.; Zhong, M.; Huang, J.; Qu, H. Multiple impacts of environmental regulation on the steel industry in China: A recursive dynamic steel industry chain CGE analysis. J. Clean. Prod. 2019, 210, 490-504. [CrossRef]

161. Gao, T.; Shen, L.; Shen, M.; Liu, L.; Chen, F.; Gao, L. Evolution and projection of CO2 emissions for China's cement industry from 1980 to 2020. Renew. Sustain. Energy Rev. 2017, 74, 522-537. [CrossRef]

162. Chertow, M.; Miyata, Y. Assessing collective firm behavior: Comparing industrial symbiosis with possible alternatives for individual companies in Oahu, HI. Bus. Strategy Environ. 2011, 20, 266-280. [CrossRef]

163. Song, X.; Geng, Y.; Dong, H.; Chen, W. Social network analysis on industrial symbiosis: A case of Gujiao eco-industrial park. J. Clean. Prod. 2018, 193, 414-423. [CrossRef]

164. Lehtoranta, S.; Nissinen, A.; Mattila, T.; Melanen, M. Industrial symbiosis and the policy instruments of sustainable consumption and production. J. Clean. Prod. 2011, 19, 1865-1875. [CrossRef]

165. van Beers, D.; Bossilkov, A.; Corder, G.; van Berkel, R. Industrial symbiosis in the Australian minerals industry: The cases of Kwinana and Gladstone. J. Ind. Ecol. 2007, 11, 55-72. [CrossRef]

166. Susur, E.; Hidalgo, A.; Chiaroni, D. A strategic niche management perspective on transitions to eco-industrial park development: A systematic review of case studies. Resour. Conserv. Recycl. 2019, 140, 338-359. [CrossRef]

167. Ashton, W.S.; Bain, A.C. Assessing the "Short Mental Distance" in eco-industrial networks. J. Ind. Ecol. 2012, 16, 70-82. [CrossRef]

168. Salvia, A.L.; Leal Filho, W.; Brandli, L.L.; Griebeler, J.S. Assessing research trends related to sustainable development goals: Local and global issues. J. Clean. Prod. 2019, 208, 841-849. [CrossRef]

169. Cui, H.; Liu, C.; Côté, R.; Liu, W. Understanding the Evolution of industrial symbiosis with a system dynamics model: A case study of Hai Hua industrial symbiosis, China. Sustainability 2018, 10, 3873. [CrossRef]

170. Neves, A.; Godina, R.; Azevedo, S.G.; Matias, J.C.O. Current status, emerging challenges, and future prospects of industrial symbiosis in Portugal. Sustainability 2019, 11, 5497. [CrossRef]

171. Tajbakhsh, A.; Shamsi, A. Sustainability performance of countries matters: A non-parametric index. J. Clean. Prod. 2019, 224, 506-522. [CrossRef]

(C) 2019 by the authors. Licensee MDPI, Basel, Switzerland. This article is an open access article distributed under the terms and conditions of the Creative Commons Attribution (CC BY) license (http://creativecommons.org/licenses/by/4.0/). 